\title{
LATE PLEISTOCENE ENVIRONMENTAL DYNAMICS AND HUMAN OCCUPATION IN SOUTHWESTERN EUROPE
}

\section{Sebastián Pérez-Díaz (1*) \& José Antonio López-Sáez (2)}

(1) Grupo de Investigación Pasado y Presente Grográfico del Relieve, la Vegetación y el Paisaje (GeoReVe), Departamento de Geografía, Urbanismo y Ordenación del Territorio, Universidad de Cantabria. E.T.S. de Ingenieros de Caminos, Canales y Puertos. Avenida de los Castros, 44, 39005, Santander, Spain.

(2) Grupo de Investigación Arqueología Medioambiental, Instituto de Historia (IH), Centro de Ciencias Humanas y Sociales (CCHS), Consejo Superior de Investigaciones Científicas, C/ Albasanz 26-28, 28037 Madrid, Spain.

*Corresponding author: Sebastián Pérez-Díaz, sebastian.perezdiaz@unican.es. Departamento de Geografía, Urbanismo y Ordenación del Territorio, Universidad de Cantabria. E.T.S. de Ingenieros de Caminos, Canales y Puertos. Avenida de los Castros, 44, 39005, Santander, Spain.

Abstract: This paper focuses on palaeoenvironmental conditions and climate variability during the Upper Late Pleistocene (c. 28,000-11,700 cal BP) in SW Europe (Iberian Peninsula) and their influence on human settlement patterns. All the palaeoenvironmental and archaeological sequences available for this period are analysed, together with a new palaeoenvironmental study related to a key deposit: Verdeospesoa mire (northern Iberian Peninsula). The multiproxy analysis (pollen, spores, non-pollen palynomorphs, magnetic susceptibility, organic content and macrocharcoal) of this sequence, with the support of six Accelerator Mass Spectrometry (AMS) radiocarbon dates, shows the climatic variability of that period, with some dry/cold and humid/temperate episodes. While in vast regions of central and northern Europe very few archaeological sites of this age are known, in the Iberian Peninsula no occupations gaps have been detected in all this period, supporting the idea of SW Europe as a glacial refugium for human groups during the worst periods of the Upper Late Pleistocene.

Key words: Palaeoenvironment; Climate variability; Human occupation; Upper Late Pleistocene; Southwestern Europe; Glacial refugia. 


\section{Introduction}

The humans-climate relationship is an issue of interest for palaeoenvironmental and archaeological studies (Banks et al., 2008; Gamble et al., 2004; Straus, 2012, 2015), taking into account that climate is a key factor for understanding the subsistence strategies, settlement patterns, and mobility of past societies (Desbrosse and Koslowski, 1988; Büntgen et al., 2011; Schmidt et al., 2012; Barton et al., 2013; Posth et al., 2016). In this sense, the causal relationship between climate fluctuation and human adaptations (in a wide sense) has long been debated (Ruff, 1994, Blockley et al., 2000). However, the link between abrupt climate changes and human mobility has only emerged in the last decade (Blockley et al., 2006). The study of this connexion is of particular interest during the Pleistocene, when glacial-interglacial succession could have influenced humans' adaptive strategies.

In the context of SW Europe, climate-human mobility links have been explored for the Holocene, relating some abrupt climate changes and cultural dynamics: e.g. the 8200 cal BP cold event and the spread of agriculture in the Mesolithic-Neolithic transition (Berger and Guilaine, 2009; González-Sampériz et al., 2009; Cortés et al., 2012), and the 4200 cal BP event and the Chalcolithic-Bronze Age transition (Fabián-García et al., 2006; Magny et al., 2009; Lillios et al., 2016). However, the relationship between climate variability and human mobility during the Upper Palaeolithic has not been explored in detail until the last decade (Gamble et al., 2004; Finlayson et al., 2006; Carrión et al., 2008; Schmidt et al., 2012; Maier et al., 2016).

The reconstruction of Pleistocene climate fluctuations from southern European terrestrial records is, however, a difficult task. The reasons are varied. On the one hand, the scarcity of available records, their resolution, difficulty in comparing reconstructions based on different proxies, and the problems of correlating their changes with Greenland ice cores, are some examples. On the other hand, the different sensitivity of each deposit to archive the signals of different climatic conditions should also be taken into account (Moreno et al., 2014).

The final stage of the Late Pleistocene (Upper Late Pleistocene, ULP) in SW Europe is a palaeoenvironmentally interesting period. At a pan-European scale, palynological, isotope and speleothems recording the end of the last glacial cycle indicate an unstable climate with large temperature and precipitation fluctuations, leading to the alternation of cold and dry episodes with other more humid and temperate phases (Dansgaard et al., 1993; Cronin, 1999; Andersen et al., 2006; Carrión et al., 2010). However, these continental-scale fluctuations are not registered in all regions of Europe, and differences in both intensity and timing make local reconstructions a challenge (Moreno et al., 2012).

The ULP is also interesting regarding human occupation dynamics. The European archaeological record reveals a relatively low number of archaeological sites and remarkable geographical gaps (Street and Terverger, 1999; Terverger and Street, 2002; Gamble et al., 2005; Blockley et al., 2006; Banks et al., 2008). The data suggest certain abandonment of central and northern European territories during the coldest phases, mainly during the Last Glacial Maximum (LGM, c. 23,000-18,000 cal BP), and the concentration of archaeological sites in southern territories (Gamble et al., 2004; Bocquel-Appel et al., 2005; Straus, 2015). These data led to the hypothesis that SW Europe was a "refugium" area for humans during the worse climate periods 
(Straus et al., 2002; Maier et al., 2016; Straus, 2016), likely influencing the ancient hunter-gatherer adaptive models to environmental conditions and the development of different techno-cultures in Europe such as the Gravettian, Solutrean and Magdalenian (Straus, 2010; Fu et al., 2016).

The available palaeo-proxy and archaeological data from c. 28,000 to $11,700 \mathrm{cal} \mathrm{BP}$ in the Iberian Peninsula are brought together here in order to shed light on the discussion about the link between climate fluctuation and human mobility during the ULP. To support the discussion, new proxy data, including pollen, non-pollen palynomorphs, magnetic susceptibility, loss-on-ignition and macrocharcoal, from the Verdeospesoa mire (Northern Iberian Peninsula) will be presented. This new record is key for three reasons: i) its biogeographical position between the Atlantic and Mediterranean regions of the Iberian Peninsula, acting as a crossroad between low latitudes in SW Europe and the Mediterranean region, hence being a refuge of biological resources in glacial times (Straus, 2015); ii) while palaeoenvironmental records from marine cores are abundant in the Atlantic margin and Bay of Biscay (Sánchez-Goñi et al., 2002; Naughton et al., 2007; Salgueiro et al., 2010; da Silva-Oliveira, 2012; Martínez-García et al., 2014), this new record is one of the few high-resolution continental records for the Iberian Peninsula, covering the c. 27,300-11,700 cal BP period; and iii) most Late Pleistocene proxy data in the Iberian Peninsula come from archaeological sites, offering information about the period of human occupation only, and not continuous pictures.

\section{Study area and study site}

The Iberian Peninsula is very sensitive to climate change, because it is one of the Mediterranean regions with the highest level of environmental heterogeneity and biological diversity, endowing it with one of the world's richest flora and biodiversity (Rivas-Martínez, 1987; Médail and Quézel, 1997; Castroviejo, 2002; Sainz-Ollero and Moreno, 2002; Costa-Tenorio et al., 2005; Myers et al., 2000). This environmental heterogeneity was also clearly defined in the past, as deduced from both palaeoenvironmental (Carrión et al., 2010) and genetic studies (Hewitt, 2000; 2003; Tzedakis et al., 2013), suggesting the existence of biological glacial refugia in the Quaternary favouring the survival of a number of temperate flora (González-Sampériz et al., 2010).

Verdeospesoa mire ( $\left.43^{\circ} 03^{\prime} 18^{\prime \prime} \mathrm{N} / 2^{\circ} 51^{\prime} 41^{\prime \prime} \mathrm{W}, 1015 \mathrm{~m}\right)$ is located in the Basque Country (Cantabrian region, Northern Iberia), on the western slopes of Gorbea mountain. It forms part of the Basque Mountains, a mountain range parallel to the coastline which limits the progressive arrival of Atlantic influences, favouring a complex and rich floristic diversity (Aseginolaza et al., 1996). It belongs to the municipality of Orozko (Gorbeia Natural Park), and occupies a small flat area of approximately $516 \mathrm{~m}^{2}$, on a geological substratum consisting of Lower Cretaceous microconglomerate sandstones (Fig. 1A, 1B). The nearest meteorological station describes humid and cool conditions, with mean annual precipitation of $1350 \mathrm{~mm}$ on 196 rainy days, without a summer drought, and a mean annual temperature of $12^{\circ} \mathrm{C}$ (Euskalmet, 2011).

The intensive pastoral exploitation of this place during the last decades determines the current vegetation of the surrounding areas (Fig. 1C). The local vegetation of the mire is formed by hygrophilous plants, typical of peatlands, like Drosera rotundifolia L, Narthecium ossifragum L. (Huds), Ranunculus flammula L. and tetralix L. In the vicinity, shrublands are the dominant plant communities, called Atlantic heaths, including Calluna vulgaris (L.) Hull., Erica vagans L., E. 
arborea L., etc. The most common herbaceous communities are pasturelands formed by Agrostis curtisii Kerguélen, Festuca rubra L., Danthonia decumbens (L.) DC., Gallium saxatile L., etc. The main forests in the area are acidophilous. Acidophilous beech forests consist of beech (Fagus sylvatica L.) with Ilex aquifolium L. and Vaccinium myrtillus L. Some acidophilous forests of Quercus robur L. are also located in the slopes of Gorbea Mountain, with Fraxinus excelsior L., Corylus avellana L., Castanea sativa Mill., Acer campestre L., Tilia platyphyllos Scop. and Ulmus glabra Huds. (Aseguinolaza et al., 1996).

\section{Material and methods}

\subsection{Compiling archaeological records}

Gravettian, Solutrean and Magdalenian Iberian archaeological sites with human occupations have been compiled. Following Aura et al. (2012), radiocarbon dates from rock art, dates with a standard deviation larger than 350 years, dates contradicting their stratigraphic position, and dates from poorly-defined archaeological levels have been rejected. When three or more radiocarbon dates were available for the same archaeological level, only the oldest and the youngest have been selected, in order to situate the human occupations of every archaeological level. A total of 417 radiocarbon dates from 108 archaeological sites are considered (Fig. 1E, Supplementary appendix).

In order to infer demographic patterns, we use the summed probability distribution (SPD) curves of the valid radiocarbon dates, the most widely-accepted tool as a proxy record of prehistoric occupation so far (Gamble et al., 2005; Shennan and Edimborough, 2007; Buchanan et al., 2008; Williams, 2012; Crema et al., 2016). The analysis has been performed with the Oxcal software (version 4.2), and calibrated to the 2 sigma range (95.4\% probability) with the INTCAL13 calibration curve (Reimer et al., 2013). This software additionally uses Bayesian statistics to model the dates.

\subsection{Compiling proxy records}

High-resolution proxy records from Iberian lakes, peatlands, speleothems, caves and marine cores with at least one quantitative climate variable (temperature, precipitation, vegetation or lake level) and with high chronological resolution and available age-depth models have been compiled. The proxy data have been compared with the NGRIP $\delta^{18}$ curve, which is the basis of the Late Glacial stratotype (Björck et al., 1998) (Fig. 1D, Fig. 2).

\subsection{Verdeospesoa record}

A $243 \mathrm{~cm}$ long core was retrieved from the Verdeospesoa mire using a Russian peat sampler (GYK type, $50 \mathrm{~cm}$ length; $5 \mathrm{~cm}$ in diameter). The lower portion of the core (180-235 cm depth), comprising Pleistocene chronologies, is the interval considered in this work. Samples were taken every 1-2 cm. The chronology is based on six Accelerator Mass Spectrometry (AMS) radiocarbon dates on plant remains and bulk material (Table 1). The dates were calibrated using CALIB 7.1 with 
the IntCal13 curve (Reimer et al., 2013). An age-depth model was performed by fitting a smooth spline curve (Type=4; smooth=0.1) using CLAM 2.2 (Blaauw, 2010) (Fig. 3).

Magnetic susceptibility (MS onwards) measurements were taken every $0.5 \mathrm{~cm}$ using a Bartington MS2E high-resolution surface scanning sensor connected to an MS3 meter (Dearing and Jones, 2003). An air measurement (zero-reading) was carried out before and after each sample reading to correct for drift using the Multisus software. Samples were also analysed for loss-onignition (LOI). They were dried for $24 \mathrm{~h}$ at $105^{\circ} \mathrm{C}$, subsequently transferred to porcelain crucibles, and then ignited at $550{ }^{\circ} \mathrm{C}$ for $4 \mathrm{~h}$. The weight loss was measured after each stage in order to quantify the organic matter (OM) content (Heiri et al. 2001). LOI is expressed as a percentage of weight loss in dried sediment.

Palynological samples were treated chemically $(\mathrm{HCl}, \mathrm{KOH}, \mathrm{HF})$ following Moore et al. (1991), together with a density separation using Thoulet solution (Goeury and de Beaulieu, 1979). Pollen grains were identified with the help of different keys and pollen atlases, such as Faegri and Iversen (1989), Moore et al. (1991) and Reille (1992), and the reference collection in the CSIC Archaeobiology Laboratory (Madrid). Non-pollen palynomorphs were identified according to van Geel (1978, 2001, 2006) and van Geel et al (1981, 1989, 2003). Pollen counts of up to 500 grains of total land pollen per sample were identified and counted. Pollen of aquatic or wetland plants as well as spores and non-pollen palynomorphs (NPP) were excluded from the pollen sum. The pollen and summary diagrams (Figs. 4 and 6) have been plotted against age using TGview (Grimm, 2004). Four local pollen assemblage zones (LPAZ 1, 2, 3 and 4) were separated on the basis of agglomerative constrained cluster analysis of incremental sum of squares (Coniss) after the squareroot transformation of percentage data (Grimm, 1987).

Ordination by principal components analysis (PCA) was performed on the fossil dataset using the C2 1.5 software (Juggins, 2007), since an initial detrended correspondence analysis (DCA) pointed to a linear response of species data to environmental gradients (ter Braak and Prentice, 1988). Samples were square-root transformed for a better comparability. Analyses were processed with all pollen and non-pollen palynomorph taxa with values larger than $2 \%$. According to the zonation obtained by Coniss, samples were classified into groups and expressed using different symbols (Fig. 5). In the PCA scatter plot, taxa are shown as distance biplot arrows, and the direction of the arrow indicates the direction in which the values of the corresponding taxa increase.

Macrocharcoal samples were sub-sampled $\left(1 \mathrm{~cm}^{3}\right)$ along the entire core following standard procedures (Whitlock and Larsen, 2001). The samples were soaked in a $10 \% \mathrm{NaOH}$ solution for 24 $\mathrm{h}$ to disaggregate organic silts, then in a $6 \% \mathrm{H}_{2} \mathrm{O}_{2}$ solution $(24 \mathrm{~h})$ to bleach the remaining noncharcoal organic material and thus make charcoal identification easier (Rhodes, 1998). Charred particles were isolated using wet sieving with a $150 \mu \mathrm{m}$ mesh (Clark, 1988; Ohlson and Tryterud, 2000; Carcaillet et al., 2001). Charcoal concentration was expressed as Charcoal Accumulation Rate (CHAR; particles $\mathrm{cm}^{-2}$ year-1) based on the sediment accumulation rate (year cm-1) (Fig. 6).

\section{Results and discussion}

\subsection{Late Pleistocene environmental changes in SW Europe: local or supra-regional signatures?}


The lower part of the Verdeospesoa record (bottom of LPAZ 1) shows a landscape characterized by the major presence of open areas (Fig. 4). The main herbaceous communities comprise grasslands (Poaceae, Fabaceae, Cardueae, Aster, Apiaceae) and xerophytic taxa (Juniperus, Artemisia, Caryophyllaceae, Chenopodiaceae, Centaurea). Trees are mainly pines, with maximum values of $21.6 \%$. However, these conifers would not be the dominant forests in the vicinity of the peat bog, since studies of current pollen rain indicate that only values over $60 \%$ indicate the presence of local pine forests (López-Sáez et al., 2013). In this case, these woodlands would probably form a band of vegetation located above the deciduous forest. The local forest was mainly formed by mesophilous trees, such as deciduous Quercus. However, their values $(<20 \%)$ suggest an open forest of oak trees, with other deciduous trees such as hazel, birch, alder and ash. At this time, the reduced local forests allowed intense erosive processes, reflected in the MS curve (Fig. 6) with two main peaks at c. 26,600 cal BP and 24,740 cal BP. The PCA analysis shows for this part of the sequence negative values in PCA-1 and PCA-2, suggesting dry and cold climatic conditions. The PCA-3 analysis shows greater variability, in relation with the forest cover (Fig. 6).

This dry and cold phase coincides with the proposed Greenland Stadial-3 (Rasmussen et al., 2014), dated in NGRIP core to between c. 27,500 and 23,300 cal BP. All northern Iberian palaeoenvironmental records display the same trends as in Verdeospesoa, as in the study of speleothems at El Pindal (Moreno et al., 2010a), the sedimentological record in Lake Enol (Moreno et al., 2010b) and the micro-vertebrates in the caves of Askondo (García-Ibaibarriaga et al., 2015) and Santimamiñe (Rofes et al., 2014), which indicate lower temperatures and lower water availability. The dominance of xerophytic taxa is also recorded on the southern slopes of the Pyrenees, at the palaeo-lake of El Portalet and in Banyoles Lake (NE Iberia), where pine forests locally reach higher values (approx. 40\%) than in the Cantabrian region (González-Sampériz et al., 2006, Pérez-Obiol and Julià, 1994). In the NW of the Iberian Peninsula, the analysis of marine sequences indicates that the Greenland Stadial-3 phase was characterized by cold Sea Surface Temperatures (SST) and high values of steppic pollen (Naughton et al., 2007), confirming the same trend as in northern Iberia. In the northern and southern plateaux of central Iberia, the palynological records from Fuentillejo and Villarquemado (Vegas et al., 2010; González-Sampériz et al., 2013), and the palaeoclimatic reconstruction based on calcite $\delta^{18} \mathrm{O}$ from Eagle Cave in central Iberia (Domínguez-Villar et al., 2013) also attest cold and dry conditions at this time, which seems to be the general trend throughout south-west Europe.

4.1.2. Warmer and wetter climate conditions (c. 23,750-21,800 cal BP) during Greenland Interstadial 2 (GI-2)

The multiproxy study of Verdeospesoa mire reflects significant palaeoenvironmental changes in a short episode c. 23,750-21,800 cal BP (middle part of LPAZ 1), which seems to be related to Greenland Interstadial 2 (Rasmussen et al., 2014). This phase is dated in NGRIP core between c. 23,300-22,900 cal BP. However, in northern Iberia its duration appears to have been longer, since these relatively more humid conditions seem to last until c. 21,800 cal BP. 
At this time, the climate seems to be warmer and humid in Verdeospesoa mire. There is a significant increase in arboreal pollen (reaching 60\%), with the dominance of mesophilous trees such as deciduous Quercus and pioneers like hazel. The only occurrence of hornbeam in c. 23,74523,580 cal BP and the first presence of beech (Fig. 4) is detected in this period. This more forested landscape is the reason for the lesser intensity of erosive processes at the local scale (Fig. 6), probably motivated by more humid conditions, as shown by the increase in hygrophytic taxa and ferns, positive values of PCA-1 (wetter environment) and PCA-3 (forested environment) (Fig. 5). In spite of being a more humid and temperate phase, the presence of xerophytic taxa is reflected in the diagram, reaching maximum values of $10 \%$ (Figs. 4 and 6), which is however less intense than in the previous GS-3 phase.

This short episode is not well recorded in many regions of the Iberian Peninsula, mainly because of its relatively short duration, so it is hard to detect in non high-resolution multiproxy analysis. Only the speleothems in El Pindal (Moreno et al., 2010a), the palaeoenvironmental reconstructions based on microvertebrates from Askondo and Santimamiñe (Rofes et al., 2014; García-Ibaibarriaga et al., 2015) and the Fuentillejo maar lacustrine record (Vegas et al., 2010) show this slight climatic amelioration.

\subsubsection{Drier and cold climate conditions (c. $21,800-16,800$ cal BP) in Greenland Stadial 2 (GS-2)}

A new drier and cold phase is detected in the Verdeospesoa record in c. $21,800-16,800$ cal BP (top of LPAZ 1). This phase seems to roughly correspond to Greenland Stadial 2 (Rasmussen et al., 2014) dated in NGRIP core to c. $22,900-14,700$ cal BP, including the LGM (23,000-18,000 cal BP) as well as the Mystery Interval (18,000-14,500 cal BP) documented in numerous regional sequences (González-Sampériz et al., 2017). In northern Iberia, the Verdeospesoa record indicates that herbs are now again the dominant vegetation, with grasslands and xerophytic taxa the main components. This greater presence of non-forested areas is defined by the negative values documented in PCA-3 (Fig. 6). At this time, deciduous forests of mainly hazel and deciduous Quercus show a regressing trend. All this is reflected in the negative values of PCA-1, indicating dry environmental conditions. Very significant in this sense is the increase in microcharcoal c. $21,480-18,000$ cal BP, when particles reach a maximum of 175 particles $\mathrm{cm}^{-2}$ year $^{-1}$. These values are not extremely high, but they are very significant since they are the highest in the whole sequence. This event is a clear indication of the occurrence of fires in the environment, favoured by the aforementioned more arid climatic conditions.

Those unfavourable climatic conditions are also recorded in a large number of palaeoenvironmental records in the Iberian Peninsula, favoured by their longer chronology and intensity, as at Askondo, Santimamiñe, Kiputx IX, El Mirón and El Pindal caves in northern Iberia (Cuenca-Bescós et al., 2008, 2009; Straus and González-Morales, 2009; Moreno et al., 2010a; Straus et al., 2011; Castaños et al., 2014; Rofes et al., 2014; Stevens et al., 2014; GarcíaIbaibarriaga et al., 2015). In Lake Enol the climate was still cold, but slight warming with higher water availability and shorter periods of ice coverage has been suggested (Moreno et al., 2010b). On the southern slopes of the Pyrenees, this dry phase related to GS-2 is also documented in Lake Estanya (Morellón et al., 2009) by shallow lake levels and reduced organic productivity, in a 
landscape dominated by steppic grasses, according to pollen records from Estanya, El Portalet and Banyoles (Pérez-Obiol and Julià, 1994; González-Sampériz et al., 2006, 2017). A similar trend is recorded on the northern Plateau (El Portalón, López-García et al., 2010), in central Iberia (Eagle Cave, Domínguez-Villar et al., 2013), and on the southern plateau (Fuentillejo lacustrine record, Vegas et al., 2010). The marine sequences analysed on the Atlantic seaboard of the Iberian Peninsula and in the Alborán Sea also indicate that the LGM was a cold and relatively dry period, although probably not as dry as Heinrich Event 2 (Rocoux et al., 2001; Naughton et al., 2007; Fletcher and Sánchez-Goñi, 2008; Salgueiro et al. 2010; Naughton et al., 2016).

4.1.4. Humid and cold climate conditions (c. 16,800-11,500 cal BP) during the Greenland Interestadial 1 (GI-1) and the Greenland Stadial 1 (GS-1)

LPAZ 2 is characterized by a new and very evident improvement in the climate. Forests rapidly expand, mainly formed by mesophilous trees such as deciduous Quercus and hazel. Also noteworthy is the increase in the representation of two species that are very dependent on humidity: beech and linden (Fig. 4). In this phase, c. 16,715-16,690 cal BP, the first presence of walnut is detected. Pines, with a certain regional presence from the beginning of the sequence, now show a downward trend. From this moment, two previously-documented steppic taxa, juniper and Artemisia, disappear at the same time as a massive increase in the general values of hydrohygrophilous taxa, reflecting more humid and possibly temperate conditions. Statistical PCA analyses also reflect this situation, with PCA-1 indicating positive values, affecting higher humidity, while PCA-3, with positive values, indicates a higher index of forest cover. Although other Iberian and European sequences record an initial warm and humid phase (GI-1, Bölling/Allërod) and another dry and cold episode (GS-1, Younger Dryas) previous to the onset of the Holocene (Pèlachs et al., 2012, Rasmussen et al., 2014; González-Sampériz et al., 2017), in Verdeospesoa mire only a clear humid and colder phase, is evident, probably because of a lower sedimentation rate and lower resolution in this part of the stratigraphy.

The increasing humidity during this phase (c. 16,800-11,500 cal BP) is clearly defined by the onset of growth in some speleothems in SW Europe. This is the case of stalagmites in Chauvet, Villars (Genty et al., 2006) and El Pindal caves (Moreno et al., 2010a). In the same way, palaeoclimatic reconstructions at Santimamiñe (Rofes et al., 2014), El Mirón (Stevens et al., 2014) and Lake Enol (Moreno et al., 2010b) show clearly warmer conditions than before, reflecting a supra-regional trend. In the Pyrenean region, this phase is represented by the deglaciation period documented in El Portalet c. 17,800-12,500 cal BP, where it is also possible to see a significant increase in arboreal pollen values (González-Sampériz et al., 2006) and in Lake Banyoles (PérezObiol and Juliá, 1994) and Estanya (Morellón et al., 2009). Also in NW Iberia, the La Roya lake (Muñoz-Sobrino et al., 2013) indicates cold but more humid conditions. In central Iberia, the speleothem record from Eagle Cave shows low $\delta^{18} \mathrm{O}$ values, interpreted as wetter periods, with the moisture source potentially contributing in part to the variability of this proxy (Domínguez-Villar 2013).

\subsection{Settlement patterns in the Iberian Peninsula during the ULP}


Before the period considered here, the Iberian Peninsula was occupied by hunter-gatherers during the Middle Paleolithic (Arsuaga et al., 2012; Ríos et al., 2013, Navazo and Carbonell, 2014) and Early Upper Paleolithic (Zilhão, 2006; Straus, 2010; Altuna et al., 2011). However, the present objective is to define the relationships between climate and human settlement patterns during the ULP, particularly in the time of the Gravettian, Solutrean and Magdalenian technocomplexes.

\subsubsection{Gravettian (c. 32,000-23,400 cal BP)}

Available records show a degree of asymmetric distribution both in the chronology and in the geographical distribution of Iberian Gravettian sites. Two main settlement concentrations have been identified (northern and Atlantic coasts), with few sites in the Mediterranean area, a significant scarcity in southern and inner Iberia, and an absence of well-dated archaeological sites in the Pyrenean region (Fig. 7).

The Cantabrian region in northern Iberia is the area in which archaeological research has detected the highest concentration of Gravettian archaeological sites and obtained the most radiocarbon dates, with 12 well-dated deposits and 22 radiocarbon dates (Fig. 7). Taking into account the chronology (Supplementary appendix), this region seems to be the area where the Gravettian lasted longer (Calvo and Prieto 2012). The main curve of Gravettian radiocarbon dates for sites with or without Noailles burins, La Gravette points and microgravettes, develops c. 32,00023,400 cal BP (Fig. 7).

In the Mediterranean region, a total of six Gravettian archaeological sites and 13 radiocarbon dates are documented (Fig. 7). Faced with the traditional hypothesis that indicated the late development of the Gravettian groups, new research points to a chronological development similar to that proposed for the main Gravettian nucleus of northern Iberia (Villaverde and Román, 2004, Vega and Martín, 2006) and earlier than in other regions. In this area, this technocomplex seems to have developed between the oldest well-dated deposit of Finca Doña Martina (c. 31,312-30,795 cal BP; 800 years after the initial Gravettian in the north) and the youngest at Arbreda (c. 24,86823,658 cal BP; 250 years before the end of the northern Gravettian). In this case, no concentration of archaeological sites is detected, since those six sites are located along the whole Mediterranean coast, from the north (Arbreda) to the south (Finca Doña Martina).

In southern Iberia, only the archaeological sites of Nerja (dated c. 29,400-27,800 cal BP) and Vale Boi (c. 29,300-25,700 cal BP) have been documented, so it is difficult to explore the settlement distribution and chronology of the Gravettian in this region in depth because of this scarce record (two sites and only 7 radiocarbon dates).

On the Atlantic coast of Portugal, most of the Gravettian sites are located in an interesting concentration in its central sector, where eight archaeological sites (19 radiocarbon dates) have been recorded (Fig. 7). In this case, the duration of the Gravettian in any of its identified facies (ancient Gravettian, Fontesantian and early Gravettian) is shorter than in the north and Mediterranean regions, because it is dated c. 30,886-29,484 cal BP in Caldeirao and c. 25,175-24,271 cal BP in Alecrim (Zilhão, 1997). 
Finally, only two archaeological sites are known in inner Iberia: El Palomar (31,000-25,600 cal BP) and Peña Capón (25,800-23,600 cal BP). In the same way as in southern Iberia, it is difficult to infer any clear settlement beyond the indubitable presence of groups of hunter-gatherers in inner Iberia during the Gravettian (Alcaraz-Castaño et al., 2012).

\subsubsection{Solutrean (c. $27,800-18,300$ cal BP)}

During the Solutrean, in northern Iberia the available archaeological record shows, as in the Gravettian, an interesting nucleus, with a total of 17 well-dated deposits (43 radiocarbon dates). Some of the sites were already occupied during the Gravettian and also contain Solutrean occupations, probably showing some kind of cultural continuity (Calvo and Prieto, 2012). In addition, other new sites are added to the Solutrean archaeological record, and this is the region in the whole Iberian Peninsula where most deposits have been identified (Fig. 7). Their chronological framework is dated between the oldest Hornos de la Peña Level C (c. 25,153-23,555 cal BP) and the youngest record from the Solutrean Level IV in Cueva del Ruso, (c. 20326-19255 cal BP), with a short overlapping period with the preceding Gravettian technocomplex. In this period, in the Pyrenean area the first well-dated deposit, Chaves, has a chronology of c. 24,422-22,947 cal BP.

In the Mediterranean region, the archaeological record shows a clear increase in the number of sites, from 6 in the Gravettian to 11 in the Solutrean. Whereas some were already cited in the Gravettian record, the others (a total of eight) are new Solutrean sites, all concentrated in the southern part of the Mediterranean coast (Fig. 7). The Solutrean in this region is dated between Level IV in Cueva Ambrosio (26,030-25,595 cal BP) and Level II (ext) in Cueva Beneito (c. 19,930-19,148 cal BP). Thus, this technocomplex seems to develop earlier and last longer than in the north.

The previously recorded sites in southern Iberia, Vale Boi and Nerja, also have Solutrean occupations, as well as such new sites as Cueva del Gato and Gorham's Cave. In total four archaeological sites (13 radiocarbon dates) whose chronology covers from Level V (9) in Nerja (c. 25,863-25,042 cal BP) to Nerja Level V (8i) dated c. 19,938-18,303 cal BP), suggesting a longer duration of this technocomplex than in the Mediterranean region.

In the central Atlantic coast of Portugal, seven Solutrean sites (11 radiocarbon dates) are known, compared with eight in the Gravettian. They are all concentrated at the mouth of the Tagus and Mondego rivers (Fig. 7). The chronological framework begins in Cabeço do Porto Marinho Level III inf. dated c. 27,590-26,210 cal BP (which is the oldest radiocarbon date in the whole Iberian Solutrean) and finishes in Level 9 at Buraca Grande (c. 22,151-21,024 cal BP), so it seems to be a shorter-lasting technocomplex than in the other Iberian regions.

Finally, in the inner Iberian Peninsula, 4 archaeological sites are recorded, contrasting with the Gravettian, for which only two deposits have been identified, with chronologies between c. 25,817-25,263 cal BP in Peña Capón Level 4, which is one of the oldest Gravettian dates in the whole Peninsula, and c. 21,881-21,328 cal BP in Maltravieso. In this case, the scarcity of radiocarbon dates and the distance between them reveal clear discontinuity in the probability density curve (Fig. 7), which is probably far from the archaeological reality (Alcaraz-Castaño et al., 2013, 2017). 
As in the previous periods, Magdalenian hunter-gatherer groups found northern Iberia to be one of the most suitable areas to live at the end of the Pleistocene. A large number of archaeological sites have been recognized; in sum 35 sites (116 radiocarbon dates) have been recorded (Fig. 7). The Magdalenian in this region is the earliest in the whole of Iberia, dated c. 21,288-20,733 cal BP in Level 26 at El Mirón, and it lasted until El Castillo Level 6 and c. 12,548-11,695 cal BP. Thus, this technocomplex covers a long period of c. 9000 years, overlapping with the last Solutrean occupations in this region. In addition, those sites are distributed in all northern areas, from the east to the west, with the first well-dated archaeological sites in the NW region, such as Valdavara 1, 2, 3 (Alonso et al., 2012) and Cueva Eiros (Fabregas et al., 2010). In the contiguous Pyrenean area, in contrast with the previous scarcity of sites, this is the best represented period in the Upper Paleolithic with 5 archaeological sites, in a chronological framework from the oldest level of Montlleó Sect. B c. 20,662-20,071 cal BP to Forcas I Level 10 c. 13,010-127,41 cal BP.

In the Mediterranean region, during the Solutrean an interesting concentration was detected in the Valencia region, but Magdalenian settlement seems to be concentrated at higher latitudes, in the northeast (Fig. 7) (Fullola et al., 2012). Further south in the Valencia region only the site of Cendres is known. The Mediterranean Magdalenian covers from Cova Gran de Santa Linya Level EA-3 dated c. 20,502-20,030 cal BP to Molí del Salt Level A dated c. 12,945-12,707 cal BP, very close to the chronology of the Pyrenean region. As mentioned above, in southern Iberia well-dated Upper Paleolithic archaeological sites are very scarce (Fig. 7). In the case of the Magdalenian, only the sites of Nerja and Vale Boi (also with Gravettian and Solutrean) occupations have been documented, with a chronological framework from Vale Boi Level Z1 dated c. 19,125-18,903 cal BP to Nerja Level T-17 c. 13,754-13,491 cal BP.

On the central Atlantic coast of Portugal, as in previous periods (Bicho and Haws, 2012), an interesting concentration consists of six archaeological sites (34 radiocarbon dates) relatively close to each other, in a chronological framework from Level 5 in Cabeço do Porto Marinho dated c. 20,203-18,853 cal BP to Lapa dos Piceiros upper Level E at c. 11,979-11,306 cal BP. Finally, in inland Iberia, this is the best represented period in the ULP in terms of number of archaeological sites, because 12 Magdalenian sites (35 radiocarbon dates) are known (Fig. 7), with a chronology from Legintxiki Level Ia dated c. 18,428-17,731 cal BP to Peña del Diablo 1 Level 2 (c. 13,013$12,250 \mathrm{cal} \mathrm{BP})$.

\subsection{A human glacial refugium in the Iberian Peninsula during the ULP?}

Palaeoenvironmental and archaeological records in the Iberian Peninsula reveal an interesting pattern: the continuous presence of hunter-gatherer groups during the ULP with no apparent gaps because of the different climatic episodes.

The occupation of the Iberian Peninsula during the Upper Gravettian (c. 28,000-23,700 cal 
archaeological levels, have been recorded (Fig. 9), attesting the presence of human hunter-gatherer groups in the Iberian Peninsula but with a certain degree of heterogeneity in their location. The main area in which the settlements are concentrated are the Cantabrian region in northern Iberia (the most-densely occupied area in the Iberian Peninsula in the ULP) and the Atlantic coast (concentration close to the mouth of the Tagus and Mondego rivers), with scattered occupations along the Mediterranean coast. The available data suggest that settlement in these environments near the coast was favoured by more temperate conditions owing to the oceanic influence. In those regions, although the climate was cold and dry, it was probably less severe than in inner Iberia (Carrión et al., 2010), where only two well-dated sites are currently known. Nevertheless, the presence of settlements in inland territories, like El Palomar and Peña Capón, suggest some kind of occupations. In those inner areas, the traditional interpretation of the lack of archaeological sites is that this was a mostly uninhabited area during the coldest stages of the Upper Paleolithic due to harsh environmental and climatic conditions (Straus et al., 2000; Delibes and Díez, 2006). However, recent findings could induce some reinterpretations about the inland occupation during the Gravettian in term of human adaptation (Alcaraz, 2015).

Overlapping with the Gravettian (and the subsequent Magdalenian), the Iberian Solutrean (c. 27,800-18,300 BP) developed during the cold and dry conditions of the GS-3 (c. 27,300-23,750 cal BP) and GS-2 (c. 21,800-16,800 cal BP, including the LGM), with the interruption of a short warmer episode in the GI-2 (c. 23,750-21,800 cal BP), as evidenced by palaeoenvironmental records (Fig. 8).

In spite of the prevalence of those general worse conditions, archaeological data point to a clear increase in the occupation of the Iberian Peninsula, from 30 to 44 archaeological sites, 52 to 93 archaeological levels and from 66 to 107 archaeological radiocarbon determinations (Fig. 9). A significant increase in the probability density of radiocarbon data is noticeable in c. $23,700-22,500$ cal BP, in a time near the short warmer episode of the GI-2 (Fig. 8), whereas large territories in central and northern Europe were practically abandoned (Jochim et al., 1999; Gamble et al., 2004; Bocquet-Appel et al., 2005; French and Collins, 2015).

In order to explain this, some kind of mobility of hunter-gatherer groups from the north (with extreme conditions) to the more temperate south may be proposed. The LGM in central and northern Europe was characterized by intensely dry and cold conditions, with a re-advance of glaciers (Rinterknecht et al., 2006; Ivy-Ochs et al., 2008; Ballantyne, 2010). Latitudes above $50{ }^{\circ} \mathrm{N}$ were severely affected by the Scandinavian Ice Sheet (SIS), or at least experienced periglacial environments (van Vliet-Lanoë et al., 2004). This situation must have conditioned human settlement patterns, since periglacial environments sustain a low biomass, which may prevent systematic utilization by prehistoric human groups (Banks et al., 2008). In contrast, while in the Iberian Peninsula, climate conditions were equally unfavourable, as explained above, they were probably less severe. This would have been an advantage for the human occupation of Iberia, which may have acted as a glacial refugium during the worst climatic episodes in the ULP. Following Banks et al (2008), Solutrean hunter-gatherer groups faced a relatively high level of ecological risk because of the climate and they occupied wide regions, allowed by their cultural adaptation. In this context, geographical barriers like the Pyrenees were not obstacles to the occupation of other ecological niches. 
This dominance of severe conditions would condition the geographic distribution of archaeological sites in the Iberian Peninsula. In the same way as in the Gravettian, most Solutrean sites are located in coastal environments, mainly in the north, Mediterranean area and Atlantic coast. In those areas, the milder climate (in comparison with inner territories) favoured the availability of food resources of both marine (Aura et al., 2016) and terrestrial origin, i.e. biomass of ungulates (Bocquet-Appel and Demars, 2005; Straus, 2015). Few Solutrean archaeological sites are located in inner Iberia, with a more continental climate (González-Sampériz et al., 2010) shown by the prevalence of steppic pollen taxa and low lake productivity in Fuentillejo maar (Fig. 8). However, new finds of Solutrean deposits in the interior probably indicate the organized occupation of the Iberian plateaux in this period (Baena and Carrion 2002; Tapias et al., 2012; Alcaraz-Castaño et al., 2013; Alcaraz-Castaño et al., 2017).

The Magdalenian technocomplex developed in the Iberian Peninsula from c. 21,300-11,300 cal BP, during the dry and cold conditions of the GS-2 (c. 21,800-16,800 cal BP), the warmer GI-1 (16,800-12,900 cal BP, Bølling-Allerød) and the cold GS-1 (c. 12,900-11,700 cal BP, Younger Dryas). As stated above, neither GI-1 nor GS-1 are recorded in Verdeospesoa mire, but they are clearly defined in other Iberian (Pèlachs et al., 2012, González-Sampériz et al., 2017) and European sequences (Rasmussen et al., 2014). Available data suggest that the two severe climate phases (GS2 and Younger Dryas) were not as cold and dry as the previous GS-3, as seen in the downward trend of xerophytic taxa in the Siles lagoon (Fig. 8) (Carrion, 2002).

At this time, the Magdalenian settlement pattern shows a new increase in the number of archaeological sites, reaching 69 sites and 244 radiocarbon dates from 200 archaeological layers (Fig. 9). This is therefore probably the best-known prehistoric technocomplex in the Upper Palaeolithic (Fullola et al., 2012). During the development of this prehistoric culture, a first increasing trend is observed in the probability curve from the first stages of this technocomplex, $\mathrm{c}$. 20,000-17,600 cal BP (Fig. 8), coinciding with the end of the LGM, in c. 23,000-18,000 cal BP. As in the previous Solutrean, this increasing trend must be correlated with extreme conditions in central and northern Europe, as the Iberian Peninsula received populations from other uninhabitable European regions. The area in which this increasing trend is most obvious is northern Iberia, and to a lesser extent the Pyrenean area.

After that time, a new and larger increase in the probability curve of radiocarbon data is detected c. 15,500 to 13,000 cal BP (Fig. 8). In this case, while population in northern, Pyrenean and Mediterranean areas displays some stability, the Atlantic coast of Portugal, and inner and southern Iberia show noticeable increments in the probability curve of radiocarbon data, indicating more consistent occupation of those regions (Fig. 8). This coincides with the end of the GS-2 and the GI-1, which were not as cold as previously and with more water availability, highlighting once again the great capacity of mobility and adaptation to changing environmental situations displayed

\section{Conclusions}


with a certain component of steppic vegetation and higher water availability c. $23,750-21,800$ cal BP, a new drier but temperate episode c. 21,800-16,800 cal BP with incidence of natural fires, and, a final stage which seems to reflect the deglaciation period from c. 16,800 cal BP, with the gradual passage to warmer and humid conditions before the beginning of the Holocene. In northern areas, climate changes were more subdued than in the south, where deposits seem to have been more sensitive to environmental changes.

The analysis of settlement patterns in the Iberian Peninsula in this chronological framework suggests a relatively intense occupation, with no apparent interruptions in this part of SW Europe during the MIS-2 (c. 28,000-11,700 cal BP), but with a clear geographic distribution of sites. In the Gravettian, Solutrean and Magdalenian technocomplexes, which developed during the different climatic phases, most of the settlements were located near coastal environments. The availability of prey, marine resources and suitable raw materials, combined with the less severe conditions favoured the occupation of those regions. However, continental regions with more severe climatic conditions, like inner Iberia, were also occupied during those periods, although in the present state of our knowledge it seems that population density was lower.

A global analysis of the environmental conditions and archaeological record shows that, in SW Europe (Iberian Peninsula), less severe climatic conditions than in north and central Europe allowed intense human occupation of Iberia by hunter-gatherer groups. This supports the hypothesis that this, the south-westernmost corner of Europe, was a glacial refugium for humans in the ULP, highlighting the mobility strategies and adaptations of hunter-gatherer groups in SW Europe.

\section{CRediT author statement}

Sebastián Pérez-Díaz: Conteptualization, Methodology, Writing Original draft. José Antonio López-Sáez: Methodology, Formal analysis, Funding acquisition.

\section{References}

Alcaraz-Castaño, M., López-Recio, M., Roca, M., Tapias, F., Rus, I., Baena, J., Morín, J., Pérez-González, A., Santonja, M., 2012. Nuevos datos sobre el yacimiento paleolítico de Las Delicias: Un taller solutrense en el valle del Manzanares (Madrid, España). Espacio, Tiempo y Forma, serie I, Prehistoria y Arqueología 5, 427-446.

Alcaraz-Castaño, M., Alcolea, J. de Balbín, R., García Valero, M.A., Yravedra, J., Baena, J., 2013. Los orígenes del Solutrense y la ocupación Pleniglaciar del interior de la Península Ibérica: Implicaciones del nivel 3 de Peña Capón (valle del Sorbe, Guadalajara). Trabajos de Prehistoria 70(1), 28-53.

Alcaráz-Castaño, M., 2015. Central Iberia around the Last Glacial Maximum. Hopes and prospects. J Anthropol Res 71, 565-578.

Alcaraz-Castaño, M., López-Recio, M., Tapias, F., Cuartero, F., Baena, J., Ruiz-Zapata, B., Morín, J., Pérez-González, A., Santonja, M., 2017. The human settlement of Central Iberia during 
MIS 2: New technological, chronological and environmental data from the Solutrean workshop of Las Delicias (Manzanares River Valley, Spain). Quatern Int. 431, part B, 104-124.

Alonso, S., Vaquero, M., Armeijenda, A., 2012. La Cova de Valdavara y valdavara 3 (Becerreá, Lugo). In: Sala-Ramos, R. (Ed), Los cazadores recolectores del Pleistoceno y del Holoceno en Iberia y el Estrecho de Gibraltar: estado actual del conocimiento del registro arqueológico. Universidad de Burgos, Burgos, pp. 31-34.

Altuna, J., Mariezkurrena, K, Ríos, J., 2011. Ocupaciones humanas en Aitzbitarte III (País Vasco) 33.600-18.400 BP (Zona de entrada a la cueva). Gobierno Vasco, Vitoria-Gasteiz.

Andersen, K.K., Svensson, A., Johnsen, S.J, Rasmussen, S.O., Bigler, M., Rothlisberger, R., Ruth, U., Siggaard-Andersen, M.L., Steffensen, J.P., Dahl-Jensen, D., Vinther, B.M., Clausen, H.B., 2006. Quaternay Sci Rev. 25, 3246-3257.

Arsuaga, J.L., Baquedano, E., Pérez-González, Sala, N., Quam, R.M., Rodríguez, L., García, L., Álvarez-Lao, D.J., Laplana, C., Huguet, R., Sevilla, P., Maldonado, E., Blain, H.A., RuizZapata, M.B., Sala, P., Gil-García, M.J., Uzquiano, P., Pantoja, A., Márquez, B., 2012. Understanding the ancient habitats of the last interglacial (Late MIS 5) neanderthels of central Iberia: Palaeoenvironmental and taphonomic evidences from the Cueva del Camino (Spain) site. Quatern Int. 275, 55-75.

Aseginolaza, C., Gómez, D., Lizaur, X., Monserrat, G., Morante, G., Salaverría, M.R., Uribe Etxebarria, P.M., 1996. Vegetación de la Comunidad Autónoma del País Vasco. Gobierno VascoEusko Jaurlaritza, Vitoria-Gasteiz.

Aura, J.E., Tiffagom, M., Jordá, J.F., Duarte, E., Fernández de la Vega, J., Santamaría, D., de la Rasilla-Vives, Ripoll, M., 2012. The Solutrean-Magdalenian transition: A view from Iberia. Quatern Int. 272-273, 75-87.

Aura, J.E., Jordá, J.F., Álvarez, E., Pérez-Ripoll, M., Avezuela, B., Morales-Pérez, J.V., Rodrigo, M.J., Marlasca, R., Alcover, J.A., Jardón, P., Pérez-Herrero, C.I., Pardo-Gordó, S., Maestro, A., Villalba, M.P., Salazar, D.C., 2016. Palaeolithic-Epipalaeolithic seapeople of the Southern iberian coast (Spain): an overveiw. Seánces de la Societé Préhistorique Française 6, 69-92.

Baena, J., E. Carrión., 2002. Los materiales solutrenses. In: C. Blasco (Ed), La Colección Bento del Museu d'Arqueologia de Catalunya: Una nueva mirada a la prehistoria de Madrid. Museu d'Arqueologia de Catalunya, Barcelona, pp. 79-130.

Ballantyne, C.K., 2010. Extent and deglacial chronology of the last British-Irish ice Sheet: implication of the exposure dating using cosmogenic isotopes. J Quaternary Sci. 24, 515-534.

Banks, W.E., d`Errico, F., Peterson A.T., Vanhaeren, M., Kageyama, M., Sepulchre, P., Ramstein, G., Jost, A., Lunt, D., 2008. Human ecological niches and ranges during the LGM in Europe derived from an application of eco-cultural niche modeling. J Archaeol Sci. 35, 481-491.

Barton, C.M., Villaverde, V., Zilhao, J., Aura, J.E., García-Puchol, O., 2013. In glacial environments beyond glacial terrains: humans eco-dynamics in late Pleistocene Mediterranean Iberia. Quatern Int. 318, 53-68.

Berger, J.F., Guilaine, J., 2009. The 8200 cal BP abrupt environmental change and the Neolithic transition. A Mediterranean perspective. Quaternary International 200, 31-49.

Bicho, N. Haws, J., 2012. The Magdalenian in central and southern Portugal: Human ecology at the end of the Pleistocene. Quatern Int. 272, 6-16. 
Björck, S., Walker, M.J.C., Cwynar, L.C., Johnsen, S., Knudsen, K.-L., Lowe, J.J., Wohlfarth, B., 1998. An event stratigraphy for the Last Termination in the North Atlantic region based on the Greenland ice-core record: a proposal by the INTIMATE group. J Quaternary Sci. 13, 283-292.

Blaauw, M., 2010. Methods and code for "classical" age-modelling of radiocarbon sequences. Quat Geochronol. 5, 512-518.

Blockley, S.P.E., Donahue, R.E., Pollard, A.M., 2000. Rapid human response to Late Glacial climate change: a reply to Housley et al. 2000. Antiquity. 74, 427-428.

Blockley, S.P.E., Blockley, S.M., Donahue, R.E., Lane,C.S., Lowe, J.J., Pollard, A.M., 2006. The chronology of abrupt climate change and Late Upper Palaeolithic human adaptation in Europe. J Quaternary Sci. 21 (5), 575-584.

Bocqet-Appel, J.P., Demars, P.Y., Noiret, L., Dobrowsky, D., 2005. Estimates of Upper

640 641

ter Braak, C.J.F., Prentice, I.C., 1988. A theory of gradient analysis. Advances in Ecologycal Research 18, 271-317.

Buchanan, B., Collard, M., Edinborough, K., 2008. Palaeo-Indian Demography and the Extraterrestrial Impact Hypothesis. Proceedings of the National Academy of Sciences 105, 1165111654.

Büntgen, U., Tegel, W., Nicolussi, K., McCormick, M., Frank, D., Trouet, V., Kaplna, J.O., Herzih, F., Heussner, K.U., Wannera, H., Luterbarcher, J., Esper, J., 2011. 2500 years of European climate variability and human susceptibility. Science 331, 578-582.

Calvo, A., Prieto, A., 2012. El final del Gravetiense y el comienzo del Solutrense en la Península Ibérica. Un estado de la cuestión acerca de la cronología radiocarbónica en 2012. Espacio, tiempo y Forma, Serie I, Prehistoria y Arqueología 5, 131-148.

Carcaillet, C., Bouvier, M., Frechette, B., Larouche, A.C. and Richard, P.J.H., 2001. Comparison of pollen slide and sieving methods in lacustrine charcoal analyses for local and regional fire history. The Holocene 11 (4), 67-76.

Carrión, J.S., 2002. Patterns and processes of Late Quaternary environmental change in a montane region of southwestern Europe. Quaternary Sci Rev. 21, 2047-2066.

Carrión, J.S., Finlayson, C., Fernández, S., Finlayson, G., Allué, E., López-Saéz, J.A., LópezGarcía, P., Gil-Romera, G., Bailey, G., González-Sampériz, P., 2008. A coastal reservoir of biodiversity for Upper Pleistocene human populations: palaeoecological investigations in Gorham's Cave (Gibraltar) in the context of the Iberian Peninsula. Quaternary Sci Rev. 27, 2118-2135.

Carrión, J.S., Fernández, S., González-Sampériz, P., Gil-Romera, G., Badal, E., Carrión, Y., López Merino, L., López-Sáez, J.A. Fierro, E., Burjachs, F., 2010. Expected trends and susprises in the Lateglacial and the Holocene vegetation at the Iberian Peninsula and Balearic Islands. Rev Palaeobot Palyno. 162, 458-475.

Castaños, J., Zuluaga, M.C., Ortega, L.A., Murelaga, X., Alonso, A., Rofes, J., Castaños, P.M., 2014. Carbón and nitrogen stable isotopes of bone collagen of large herbivores from the Late Pleistocene Kiputz IX cave site (Gipuzkoa, North Iberian peninsula) for palaeoenvironmental reconstruction. Quatern Int. 339-340, 131-138. 
Castroviejo, S., 2002. Riqueza florística de la Península Ibérica e Islas Baleares. El proyecto "Flora Ibérica". In: Pineda, F.D., de Miguel, J.M., Casado, M.A., Montalvo, J. (Eds.), La Diversidad Biológica de España. Pearson Educación, Madrid, pp. 167-174.

Clark, J.S.,1988. Particle motion and the theory of charcoal analysis: source area, transport, deposition and sampling. Quaternary Res. 30, 67-80.

Cortés, M., Jimenez-Espejo, F., Simón, M.D., Gibaja, J.F., Carvalho, A.F., Martínez, F., Rodrigo, M., Flores, J.A., Paytan, A., López-Sáez, J.A., Peña-Chocarro, L., Carrón, J.S., Morales, A., Roselló, E., Riquelme, J.A., Dean, R.M., Salgueiro, E., Martínez, R., de la Rubio, J., Lozano, M.C., Vera, J.L., Llorente, L., Bicho, N., 2012. The Mesolithic-Neolithic transition in southern Iberia. Quaternary Res. 77 (2), 221-234.

Costa-Tenorio, M., Morla-Juaristi, C, Sainz-Ollero, H. (Eds.), 2005. Los bosques ibéricos. Una interpretación geobotánic. Planeta, Barcelona.

Crema, E.R., Habu, J., Kobayashi, K., Madella, M., 2016. Summed probability distribution of ${ }^{14} \mathrm{C}$ dates suggest regional divergences in the population dynamics of the Jomon period in Eastern Japan. Plos One, DOI:10.1371/journal.pone.0154809.

Cronin, T.M., 1999. Principles of paleoclimatology. Columbia University Press, New York.

Cuenca-Bescós, G., Straus, L.G., González Morales, M.R., García Pimienta, J.C., 2008. Paleoclima y paisaje del final del cuaternario en Cantabria: los pequeños mamíferos del Mirón (Ramales de la Victoria). Revista Española Paleontología 23, 91-126.

Cuenca-Bescós, G., Straus, L.G., González-Morales, M.R., García-Pimienta, J.G., 2009. The reconstruction of past environments through small mammals: from the Mousterian to the Bronze Age in El Mirón Cave (Cantabria, Spain). J Archaeol Sci. 36, 947-955.

Dansgaard, W., Johnsen, S.J., Clausen, H.B., Dahl-Jensen, D., Gundestrup, N.S., Hammer, C.U., Hvidberg, C.S., Steffensen, J.P., Sveinbjörnsdottir, A.E., Jouzel, J., Bond, G., 1993. Evidence for general instability of past climate from a 250-kyr ice-core record. Nature 364, 218-220.

Dearing, J.A., Jones, R.T., 2003. Coupling temporal and spatial dimensiond of global sediment flux through lake and marine sediment records. Global and planetary change 39, 147168.Domínguez-Villar, D., Carrasco, R.M., Pedraza, J., Cheng, H., Edwards, R.L., Willenbring, J.K. 2013. Early maximum extent of paleoglaciers from Mediterranean mountains during the last glaciations. Science Report 3, doi: 10.1038/srep02034.

Delibes, G., F. Díez., 2006. ¿Una Meseta desolada? Estado actual de la investigación sobre el Paleolítico superior en las regiones interiores de la Península Ibérica. In: Delibes, G., Díez, F. (Eds.), El Paleolítico superior en la Meseta Norte española. Universidad de Valladolid, Valladolid, pp. 11-40.

Desbrosse, R.; Koslowski, J., 1988. Homme et climats à l'âge du mammouth. Masson, París.

Domínguez-Villar, D., Carrasco, R.M., Pedraza, J., Cheng, H., Edwards, R.L., Willenbring, J.K., 2013. Early maximum extent of paleoglaciers from Mediterranean mountains during the last glaciation. Science Report 3, 1-6.

EUSKALMET, 2011. Tabla de parámetros meteorológicos. Available at: http://www.euskalmet.euskadi.net/s07-5853x/es/contenidos/informacion/cli_2013/ es_clieus/ adjuntos/capitulo03(2013).pdf (accesed 15 October 2016). 
Fabián-García, J.F., Blanco, A., López-Sáez, J.A., 2006. La transición Calcolítico-Bronce Antiguo desde una perspectiva arqueológica y ambiental: el Valle de Amblés (Ávila) como referencia. Arqueología Espacial, 26, 37-56.

Fábregas, R., Alonso, S., Ameijenda, A., Grandal, A., Lazuén, de Lombera, Pérez-Alberti, A., Pérez-Rama, M., Rodríguez-Álvarez, X.P., Serna, M.R., vaquero, M., 2010. Completando o mapa. Novas datacións absolutas para o Paleolítico e mesolítico do interior galego. Gallaecia 29, 5-28.

Faegri, K., Iversen, J., 1989. Textbook of pollen analysis, 4th ed. Wiley, Chichester.

Finlayson, C., Giles-Pacheco, F., Rodríguez-Vidal, J., Fa, D.A., Guiterrez-López, J.M., Santiago-Pérez, A., Finlayson, G., Allue, E., Baena-Preysler, J., Cáceres, I., Carrión, J.S., Fernaández-Jalvo, Y., Gleed-Owen, C.P., Jimenez-Espejo, F.J., López, P., López-Sáez, J.A., Riquelme-Cantal, J.A., Sánchez-Marco, A., Giles-Guzman, F., Brown, K., Fuentez, N., Valarino, C.A., Villalpando, A., Stringer, C.B., Martinez-Ruiz, F., Sakamoto, T., 2006. Late survival of Neanderthals at the southernmost extreme of Europe. Nature 443, 850-853.

Fletcher, W.J., Sánchez-Goñi, M.F., 2008. Orbital and sub orbital scale climate impacts on vegetation of the western Mediterranean basin over the last 48,000 yr. Quaternary Res. 70, 451-464.

French, J.C., Collins, C., 2015. Upper Palaeolithic population histories of Southwestern France: a comparison of the demographic signatures of ${ }^{14} \mathrm{C}$ date distributions and archaeological site counts. J Archaeol Sci. 55 122-134.

Fu, Q., Posth, C., Hajdinjak, M., Petr, M., Mallick, S., Fernandes, D., Furtwängler, A., Haak, W., Meyer, M., Mittnik, A., Nickel, B., Peltzer, A., Rohland, N., Slon, V. Talamo, S., Lazaridis, I., Lipson, M., Mathieson, I., Schiffels, S., Skoglund, P., Derevianko, A.P., Drozdov, N., Slavinsky, V., Tsybankov, A., Cremonesi, R.G., Mallegni, F., Gély, B., Vacca, E., González-Morales, M.R., Straus, L.G., Neugebauer-Maresch, C., Teschler-Nicola, M., ConstantinS., Moldovan, O.T., Benazzi, S., Peresani, M., Coppola, D., Lari, M., Ricci, S., Ronchitelli, A., Valentin, F., Thevenet, C., Wehrberger, K., Grigorescu, D., Rougier, H., Crevecoeur, I., Flas, D., Semal, P., Mannino, M.A., Cupillard, C., Bocherens, H., Conard, N.J., Harvati, K., Moiseyev, V., Drucker, D.G., Svoboda, J., Richards, M.P., Caramelli, D., Pinhasi, R., KelsoJ., Patterson, N., KrauseJ., Pääbo, S., Reich, D., 2016. The genetic history of Ice Age Europe. Nature, doi:10.1038/nature17993.

Fullola, J.M., Mangado, X., Tejero, J.M., Petit, M.A., Bergadà, M.M., Nadal, J., GarcíaArguelles, P., Bartrolí, R., Mercadal, O., 2012. The Magdalenian in Catalonia. Quatern Int. 272273, 55-74.

Gamble, C., Davies, W., Pettitt, P., Richards, M., 2004. Climate change and evolving human diversity in Europe during the last glacial. Philosophical Transactions of the Royal Society of London B: Biological Sciences B359, 243-254.

Gamble, C., Davies, W., Pettit, P., Hazelwood, L., Richards, M., 2005. The Archaeological and Genetic Foundations of the European Population during the Late Glacial: Implications for 'Agricultural Thinking'. Camb Archaeol J. 15 (2), 193-233.

Garcia-Ibaibarriaga, N., Rofes, J., Bailon, S., Garate, D., Rios-Garaizar, J., Martínez-García, B., Murelaga, X., 2015. A palaeoenvironmental estimate in Askondo (Bizkaia, Spain) using small vertebrates. Quatern Int. 364, 244-254.

van Geel, B., 1978. A palaeoecological study of Holocene peat bog sections in Germany and The Netherlands. Rev Palaeobot Palyno. 25, 1-120. 
van Geel, B., 2001. Non-pollen palynomorphs. In: Smol, J. P., Birks, H. J. B., Last, W. M. (Eds.), Tracking environmental change using lake sediments; volume 3: Terrestrial, algal and silicaceous indicators. Kluwer Academic Publishers, Dordrecht, pp. 99-119.

van Geel, B., 2006. Fossil ascomycetes in Quaternary deposits. Nova Hedwigia 82, 313-329.

van Geel, B., Bohncke, S. J. P., Dee, H., 1981. A palaeoecological study of an Upper Late Glacial and Holocene sequence from 'De Borchert', The Netherlands. Rev Palaeobot Palyno. 31, 367-448.

van Geel, B., Coope, G. R., van der Hammen, T., 1989. Palaeoecology and stratigraphy of the Lateglacial type section at Usselo (The Netherlands). Rev Palaeobot Palyno. 60, 25-129.

van Geel, B., Buurman, J., Brinkkemper, O., Schelvis, J., Aptroot, A., van Reenen, G., Hakbijl T., 2003. Environmental reconstruction of a Roman Period settlement site in Uitgeest (The Netherlands), with special reference to coprophilous fungi. J Archaeol Sci. 30, 873-883.

Genty, D., Blamart, D., Ghaleb, B., Plagnes, V., Causse, C., Bakalowicz, M., Zouari, K., Chkir, N., Hellstrom, J.,Wainer, K., Bourges, F., 2006. Timing and dynamics of the last deglaciation from European and North African d13C stalagmite profiles-comparison with Chinese and South Hemisphere stalagmites. Quaternary Sci Rev. 25, 2118-2142.

Goeury, C., de Beaulieu, J. L., 1979 À propos de la concentration du pollen à l'aide de la liqueur de Tholet dans les sédiments minéraux. Pollen et Spores 21, 239-251.

González-Sampériz, P., Valero-Garcés, B.L., Moreno, A., Jalut, G., García-Ruiz, J.M., MartíBono, C., Delgado-Huertas, A., Navas, A., Otto, T., Dedoubat, J.J., 2006. Climate variability in the Spanish Pyrenees during the last 30000 yr revealed by the El Portalet sequence. Quaternary Res. 66, 38-52.

González-Sampériz, P., Utrilla, P., Mazo, C., Valero-Garcés, B., Sopena, M.C., Morellón, M, Sebastián, M., Moreno, A., Martínez-Bea, M., 2009. Patterns of human occupation during the early Holocene in the Central Ebro Basin (NE Spain) in response to the $8.2 \mathrm{ka}$ climatic event. Quaternary Res. 71, 121-132.

González-Sampériz, P., Leroy, S.A.G., Carrión, J.S., Fernández, S., García-Antón, M., GilGarcía, M.J., Uzquiano, P., Valero-Garcés, B., Figueiral, I., 2010. Steppes, savannahs, forests and phytodiversity reservoirs during the Pleistocene in the Iberian Peninsula. Rev Palaeobot Palyno. $162,427-457$.

González-Sampériz, P., García-Prieto, E., Aranbarri, J., Valero-Garcés, B., Moreno, A., GilRomera, G., Sevilla-Callejo, M., Santos, L., Morellón, M., Mata, P., Andrade, A., Carrión, J.S., 2013. Reconstrucción paleoambiental del último ciclo glacial-interglacial en la Península Ibérica continental: la secuencia del Cañizar de Villarquemado (Teruel). Cuadernos de Investigación Geográfica 39 (1), 49-76.

González-Sampériz, P., Aranbarri, J., Pérez-Sanz, A., Gil-Romera, G., Moreno, A., Leunda, M., Sevilla-Callejo, M., Corella, J.P., Morellón, M., Oliva, B., Valero-Garcés, B., 2017. Environmental and climate change in the southern Central Pyrenees since the Last Glacial Maximum: A view from the lake records. Catena 149, 668-688.

Grimm, E. C., 1987. Coniss: a Fortran 77 program for stratigraphically constrained cluster analysis by the method of incremental sum of squares. Computers and Geosciences 13, 13-35.

Grimm, E. C., 2004. TGView. Illinois State Museum. Springfield, IL 62703. 
Heiri, O., Lotter, A.F., Lemacke, G., 2001. Loss-On-Ignition for estimating organic and carbonate content in sedments: reproducibility and comparability of results. J Paleolimnol. 25, 101110.

Hewitt, G.M., 2000. The genetic legacy of the Quaternary ice ages. Nature 405, 907-913.

Hewitt, G.M., 2003. Genetic consequences of climatic oscillations in the Quaternary. Philosophical Transactions of the Royal Society B: Biological Sciences 359, 183-195.

Ivy-Ochs, S., Kerschner, H., Reuther, A., Preusser, F., Heine, K., Kubik, P.W., Maisch, M., Schlüchter, Ch., 2008. Chronology of the last glacial cycle in the European Alps. J Quaternary Sci. 23 (6-7), 559-573.

Jochim, M., Herhahn, C., Starr, H., 1999. The magdalenian colonization of southern Germany. Am Anthropol. 101 (1), 129-142.

Juggins, S., 2007. C2 Version 1.5., user guide. Software for ecological and palaeoecological data analysis and visualization. Newcastle University, Neucastle-upon Tyne.

Lillios, K.T., Blanco, A., Drake, B.L., López-Sáez, J.A., 2016. Mid-late Holocene climate, demography, and cultural dynamics in Iberia: A multi-proxy approach. Quat Sci Rev. 135, 138-153.

López-García, J.M., Blain, H.A., Cuenca-Bescós, G., Ruiz-Zapata, M.B., Dorado-Valiño, M., Gil-García, M.J., Valdeolmillos, A., Ortega, A.I., Carretero, J.M., Arsuaga, J.L., Bermúdez de Castro, J.M., Carbonell, E., 2010. Palaeoenvironmental and palaeoclimatic reconstruction of the Latest Pleistocene of El Portalón Site, Sierra de Atapuerca, northwestern Spain. Palaeogeogr Palaeocl. 291, 453-464.

López-Sáez, J.A., Sánchez-Mata, D., Alba-Sánchez, F., Abel-Schaad, D., Gavilán, R.G., Pérez-Díaz, S., 2013. Discrimination of Scots pine forests in the Iberian Central System (Pinus sylvestris var. iberica) by means of pollen analysis. Phytosociologial considerations. Lazaroa 34, 191-208.

Magni, M., Vanniere, B., Zanchetta, G., Fouache, E., Touchais, G., Petrika, L., Coussot, C., Veronique, A., Simonnet, W., F. Arnaud., 2009. Possible complexity of the climate event around 4300-3800 cal BP in the central and western Mediterranean. The Holocene 19 (6), 823-833.

Maier, A., Lehmkuhl, F., Ludwig, P., Melles, M., Schmidt, I., Shao, Y., Zeeden, C., Zimmermann, A., 2016. Demographic estimates of hunteregatherers during the Last Glacial Maximum in Europe against the background of palaeoenvironmental data. Quatern Int. 425, 49-65.

Martínez-García, B., Bodego, A., Mendicoa, J., Pascual, A., Rodríguez-Lázaro, J., 2014. Late Quaternary (Marine Isotope Stage 3 to recent) sedimentary evolution of the Basque shelf (southern Bay of Biscay). Boreas 43, 973-988.

Médail, F., P. Quézel., 1997. Hot-spots analysis for conservation of plant biodiversity in the Mediterranean Basin. Ann Mo Bot Gar. 84, 112-127.

Moore, P. D., Webb, J.A., Collinson, M. E., 1991. Pollen Analysis. Blackwell Scientific Publications, London.

Morellón, M., Valero-Garcés, B., Vegas-Vilarrúbia, T., González-Sampériz, P., Romero, O., Delgado-Huertas, A., Mata, P., Moreno, A., Rico, M., Corella, J.P., 2009. Lateglacial and Holocene palaeohydrology in the western Mediterranean region: the Lake Estanya record (NE Spain). Quaternary Sci Rev. 28, 2582-2599. 
Moreno, A., Stoll, H.M., Jiménez-Sánchez, M., Cacho, I., Valero-Garcés, B., Ito, E., Edwards, L.R., 2010a. A speleothem record of rapid climatic shifts during last glacial period from northern Iberian Peninsula. Global Planet Change. 71, 218-231.

Moreno, A., Valero-Garcés, B.L., Jiménez-Sánchez, M., Domínguez, M.J., Mata, P., Navas, A., González-Sampériz, P., Stoll, H., Farias, P., Morellón, M., Corella, P., Rico, M., 2010b. The last deglaciation in the Picos de Europa National Park (Cantabrian Mountains, northern Spain). J Quaternary Sci. 25, 1076-1091.

Moreno, A., González-Sampériz, P., Morellón, M., Valero-Garcés, B.L., Fletcher, W.J. 2012. Northern Iberian abrupt climate change dynamics during the last glacial cycle: a view from lacustrine sediments. Quaternary Sci Rev. 36, 139-153.

Moreno, A., Svensson, A., Brooks, S.J., Connor, S., Engels, S., Fletcher, S., Genty, D., Labuhn, I., Persoui, A., Peyron, O., Sadori, L., Valero-Garcés, B., Wulf, S., Zanchetta, G., 2014. A compilation of Western European terrestrial records 60-8 ka. BP: Towards understanding of latitudinal climatic gradients. Quaternary Sci Rev. 106, 167-185.

Muñoz-Sobrino, C., Heiri, O., Hazekamp, M., van der Velden, D., Kirilova, E.P., GarcíaMoreiras, I., Lotter, A.F., 2013. New data on the Lateglacial period of SW Europe: a high resolution multiproxy record from Laguna de la Roya (NW Iberia). Quaternary Sci Rev. 80, 58-77.

Myers, N., Mittermeier, R.A., Mittermeier, C.G., da Fonseca, G.A.B., Kent, J., 2000. Biodiversity hotspots for conservation priorities. Nature 403, 853-858.

Naughton, F., Sánchez-Goñi, M.F., Desprat, S., Turon, J.L., Duprat, J., Malaize, B., Joly, C., Drago, T., Freitas, M.C., 2007. Present-day and past (last 2500 years) marine pollen signal of Western Iberia. Mar Micropaleontol. 63, 91-114.

Naughton, F., Sánchez-Goñi, M.F., Rodrigues, T., Salgueiro, E., Costas, S., Desprat, S., Duprat, J., Michel, E., Rossignol, L., Zaragosi, S., Voelker, A.H.L., 2016. Climate variability across the last deglaciation in NW Iberia and its margin. Quatern Int. 414, 9-22.

Navazo, M., Carbonell, E., 2014. Neanderthal settlement pattern during MIS 4-3 in Sierra de Atapuerca (Buergos, Spain). Quatern Int. 331, 267-277.

Ohlson, M., Tryterud, E., 2000. Interpretation of the charcoal record in forest soils: forest fires and their production and deposition of macroscopic charcoal. The Holocene 10, 519-25.

Pèlachs, A., Rodríguez, J.M., Pérez-Obiol, R., Julià, R., Burjachs, F., Expósito, I., Cunill, R., Soriano, J.M., Yll, E.I., 2012. Dinámica climática y paisajística del Pirineo leridano durante la transición Tardiglaciar-Holoceno. Cuaternario y Geomorfología 26 (3-4), 79-96.

Pérez-Obiol, R., Julià, R., 1994. Climatic change on the Iberian Peninsula recorded in a 30,000-yr pollen record from Lake Banyoles. Quaternary Res. 41, 91-98.

Posth, C., Renaud, G., Mittnik, A., Drucker, D.G., Rougier, H., Cupillard, C., Valentin, F., Thevenet, C., Furtwängler, A., Wibing, C., Franken, M., Malina, M., Bolus, M., Lari, M., Gigli, E., Capecchi, G., Crevecour, I., Beauval, C., Flas, D., Germonpré, M., van der Plicht, J., Cottiaux, G., Gély, B., Ronchitelli, A., Wehrberger, K., Grigourescu, D., Svoboda, J., Semal, P., Caramelli, D., Bocjerenes, H., Harvati, K., Conrad, N.J., Haak, W., Krause, J., 2016. Pleistocene mitochondrial genomes suggest a single major dispersal of non-africans and Late Glacial populations turnover in Europe. Curr Biol. 26, 1-7. 
Rasmussen, S.O., Bigler, M., Blockley, S.P., Blunier, T., Buchardt, S.L., Clausen, H.B., Cvijanovic, I., Dahl-Jensen, D., Johnsen, S.J., Fischer, H., Gkinis, V., Guillevic, M., Hoek, W.Z., Lowe, J.J., Pedro, J.B., Popp, T., Seierstad, I.K., Steffensen, J.P., Svensson, A.M., Vallelonga, P., Vinther, B.M., Walker, M.J.C., Wheatley, J.J., Winstrup, M., 2014. A stratigraphic framework for abrupt climatic changes during the Last Glacial period based on three synchronized Greenland icecore records: refining and extending the INTIMATE event stratigraphy. Quaternary Sci Rev. 106, $14-28$.

Reille, M., 1992. Pollen et Spores d'Europe et d'Afrique du Nord. Laboratoire de Botanique Historique et Palynologie, Marseille.

Reimer P. J., Bard E., Bayliss A., Beck J. W., Blackwell P. G., Bronk Ramsey C., Buck C. E., Cheng H., Edwards R. L., Friedrich M., Grootes P. M., Guilderson T. P., Haflidason H., Hajdas I., Hatté C., Heaton T. J., Hoffmann D. L., Hogg A. G., Hughen K. A., Kaiser K. F., Kromer B., Manning S. W., Niu M., Reimer R. W., Richards D. A., Scott E. M., Southon J. R., Staff R. A., Turney C. S. M., van der Plicht J., 2013. Intcal13 and marine13 radiocarbon age calibration curves 0-50,000 years cal BP. Radiocarbon 55, 1869-1887.

Rhodes, A.N., 1998. A method for the preparation and quantification of microscopic charcoal from terrestrial and lacustrine sediment cores. The Holocene 8, 113-17.

Rinterknecht, V.R., Clark, P.U., Raisbeck, G.M., Yiou, F., Bitinas, A., Brook, E.J., Marks, L., Zelcs, V., Lunkka, J.P., Pavlovskaya, I.E., Piotrowski, J.A., Raukas, A., 2006. The last deglaciation of the southeastern sector of the Scandinavian Ice Sheet. Science 311, 1449-1452.

Ríos, J., Garate, D., Gómez-Olivenza, A., 2013. La cueva de Arlanpe (Lemoa): Ocupaciones humanas desde el Paleolítico Medio Antiguo hasta la Prehistoria reciente. Diputación Foral de Bizkaia, Blbao.

Rivas Martínez, S., 1987. Memoria del MAPA de Series de Vegetación de España. Ministerio de Agricultura, Pesca y Alimentación, ICONA, Madrid.

Rofes, J. Murelaga, X., Martínez-García, B., Bailon, S., López-Quintana, J.C. GuenagaLizasu, A., Ortega, L.A., Zuluaga, M.C., Alonso-Olazabal, A., Castaños, J., Castaños P., 2014. The long paleoenvironmental sequence of Santimamiñe (Bizkaia, Spain): 20,000 years of small mammal record from the latest Late Pleistocene to the middle Holocene. Quatern Int. 364, 339-340.

Roucoux, K.H., Shackleton, N.J., de Abreu, L., Schönfeld, J., Tzedakis, C., 2001. Combined marine proxy and pollen analyses reveal rapid Iberian vegetation response to North Atlantic millennial-scale climate oscillations. Quaternary Res. 56, 128-132.

Ruff, C., 1994. Morphological adaptation to climate in modern and fossil hominids. Am J Phys Anthropol. 37: 65-107.

Sainz-Ollero, H., Moreno, J.C., 2002. Flora vascular endémica española. In: Pineda, F.D., de Miguel, J.M., Casado, M.A., Montalvo, J. (Eds.), La diversidad biológica de España. Pretince HallCYTED, pp. 175-195.

Salgueiro, E., Voelker, A.H.J., de Abreu, L., Abrantes, F., Meggers, H., Wefer, G., 2010. Temperature and productivity changes of the western Iberian margin during the last $150 \mathrm{ky}$. Quaternary Sci Rev. 29, 680-695.

Sánchez-Goñi, M.F., Cacho, I., Turon, J.L., Guiot, J., Sierro, F.J., Peypouquet, J.P., Grinmalt, J.O., Shackelton, N.J., 2002. Synchroneity between marine and terrestrial responses to millennial 
scale climatic variability during the last glacial period in the Mediterranean region. Clim Dynam. 19, 95-105.

Schmidt, I., Bradtmöeller, M., Kehl, M., Pastoors, A., Tafelmaier, Y., Weninger, B., Weninger, G.C., 2012. Rapid climate change and variability of settlrment patterns in Iberia during the Late Pleistocene. Quatern Int. 274, 179-204.

Shennan, S., Edinborough, K., 2007. Prehistoric population history: from the late glacial to the late Neolithic in central and northern Europe. J Archaeol Sci. 34, 1339-1345.

da Silva-Oliveira, D., 2012: Vegetation response to Holocene climate variability in southwestern Europe. Ph.d. thesis, Universidade de Lisboa, Lisboa.

Stevens, R.E., Hermoso, X.L., Marín-Arroyo, A.B., González-Morales, M.R., Straus, L.G., 2014. Investigation of the Late Pleistocene and Early Holocene palaeoenvironmental change at El Mirón cave (Cantabria, Spain): Insights from carbon and nitrogen isitope analyses of red deer. Palaeogeogra Palaeocl. 414, 46-60.

Straus, L.G., 2010. Breves apuntes sobre el Paleolítico Superior de la región cantábric. Estado de la cuestión 1990-2005. Nivel Cero 12, 15-34.

Straus, L.G., 2012. El Solutrense: 40 años de reflexiones por un arqueólogo norteamericano. Espacio, Tiempo y Forma, Serie I, Prehistoria y Arqueología 5, 27-36.

Straus, L.G., 2013. Qu'est-ce que 'le Solutréen'? In: SERAP Vallée de la Claise (Ed.), Le Solutréen 40 Ans aprés Smith '66. Revue Archéologique du Centre de la France 47, pp. 27-36.

Straus, L.G., 2015. Recent developments in the study of the Upper Paleolithic of the VascoCantabian Spain. Quatern Int. 364, 255-275.

Straus, L.G., 2016. Humans confront the Last Glacial Maximum in Western Europe: Reflections on the Solutrean weaponry phenomenon in the broader contexts of technological change and cultural adaptation. Quatern Int. 425, 62-68.

Straus, L.G., González-Morales, M.R., 2009. A preliminary description of Solutrean occupations in El Mirón cave (Ramales de la Victoria, Cantabria). Munibe 60, 117-137.

Straus, L.G., Bicho, N., Winegardner, A.C., 2000. The Upper Palaeolithic settlement of Iberia: First-generation maps. Antiquity 74, 553-66.

Straus, L.G., González-Morales, M.R., Fano, M.A., García-Gelabert, M.P., 2002. Last glacial human settlement in Eastern Cantabria (northern Spain). J Archaeol Sci. 29, 1403-1414.

Straus, L.G., González-Morales, Gutierrez-Zugasti, I., Iriarte, M.J., 2011. Further Solutrean evidence in El Mirón Cave. Munibe 62, 117-133.

Street, M., Terverger, T., 1999. The last Pleniglacial and the human settlement of central Europe: new information from the Rhineland site of Weisbanden-Igstadt. Antiquity 73, 259-272.

Tapias, F., M. López-Recio, I. Manzano, M. Alcaraz-Castaño, J. Morín, C. Sesé, L. Dapena, A. Alarcón, J. Yravedra, and C. Arteaga., 2012. Geoarqueología y paleontología de los depósitos de Pleistoceno Superior del antiguo arroyo Abroñigal (Cuenca del Manzanares, Madrid): el yacimiento del Puente de los Tres Ojos. Cuaternario y Geomorfología 26 (1-2), 105-32.

Terberger, T., Street, M., 2002. Hiatus or continuity? New results for the question of pleniglacial settlement in central Europe. Antiquity 76, 691-698.

Tzedakis, P.C., Emerson, B.C., Hewitt, G.M., 2013. Cryptic or mystic? Glacial tree refugia in northern Europe. Trends Ecol Evol. 28, 696-704. 
Vegas, J., Blanca Ruiz Zapata, M., Ortiz, J.E., Galán, L., Torres, T., García-Cortés, A., Gil 962 García, M.J., Pérez-González, A., Gallardo-Millán, J.L., 2010. Identification of arid phases during 963 the last 50 c. ka BP from Fuentillejo maar-lacustrine record (Campo de Calatrava Volcanic Field, 964 Spain). J Quaternary Sci. 25, 1051-1062.

965 Vega, L.G., Martín, P., 2006. Análisis preliminar de las cadenas operativas en el material 966 lítico procedente del nivel IV del Abrigo del Palomar (Yeste, Albacete). Miscelánea en homenaje a 967 Victoria Cabrera (E. Baquedano y J.M. Maíllo, eds.), Zona Arqueológica 7 (1), 396-405.

Villaverde, V., Roman, D., 2004. Avance al estudio de los niveles gravetienses de la Cova de 969 les Cendres. Resultados de la excavación del sondeo (cuadros A/B/C-17) y su valoración en el 970 971 972 973 contexto del Gravetiense Mediterráneo Ibérico. Archivo de Prehistoria Levantina XXV, 19-59.

van Vliet-Lanoë, B., Meilliez, F., Maygari, A., 2004. Distinguishing between tectonic and periglacial deformations of quaternary continental deposits in Europe. Global Planet Change. 43, 103-127.

Whitlock, C., Larsen, C., 2001. Charcoal as a fire proxy. In: Smol, J.P., Birks, H.J.B. and Last, W.M. (Eds.), Tracking environmental change using lake sediments. Terrestrial, algal and siliceous indicators. Kluwer, pp. 75-97.

Williams, A.N., 2012. The use of summed radiocarbon probability distributions in archaeology: a review of methods. J Archaeol Sci. 39, 578-589.

Zilhão, J., 1997. O Paleolitico Superior da Estremadura Portuguesa. Colibri, Lisboa.

Zilhão, J., 2006. Aurignacian, behavior, modern: issues of definition in the emergence of the European Upper Paleolithic. In: Bar-Yosef, O, Zilhao, J. (Eds.), Towards a definition of the Aurignacian (Trabalhos de Arqueologia, 45) Instituto Portugés de Arqueología, Lisboa, pp. 53-69. 
2

3

4

5

6 7

8

\section{TABLE AND FIGURE AND CAPTIONS}

Figure 1. Location of the Verdeospesoa mire and the other sites mentioned in the text. A, location of the site, $\mathrm{B}$, image of Verdeospesoa mire, $\mathrm{C}$, location of the palaeoenvironmental deposits mentioned in the text, $\mathrm{D}$, current local vegetal communities near Verdeospesoa mire, E, archaeological sites considered in this analysis.

Fig. 2. Palaeoenvironmental sequences mentioned in the text and its chronological distribution.

Figure 3. Age-depth model of Verdeospesoa mire. Lines connecting each plotted point are interpolated sediment-accumulation rates.

Figure 4. Palynological diagram of Verdeospesoa mire. Taxa with lower values are exagered (grey line, $5 \%$ ).

Figure 5. Scores for axis PCA-1, PCA-2 and PCA-3 for pollen types of all study sites.

Figure 6. Synthetic pollen diagram, CHAR, MS, OM and variation of factor scores (F1 to F3) against age (cal yr BP) and climatic events from Verdeospesoa mire. Mesophilous trees (Alnus, Betula, Corylus, Fagus, Fraxinus, Juglans, deciduous Quercus, Salix, Tilia), Pines (Pinus sylvestris type, P. pinaster), Xerophytic taxa (Juniperus, Artemisia, Chenopodiaceae, Centaurea, Cichorioideae), Hydro-hygrophytic taxa and ferns (Ranunculaceae, Cyperaceae, Filicales monolete undiff., Filicales trilete undiff., Polypodium vulgare, Pteridium aquilinum), Uppland herbs (Poaceae, Fabaceae, Caryophyllaceae, Cardueae, Aster, Apiaceae).

Figure 7. Archaeological sites and summed probability distribution of radiocarbon dates during the Gravettian, Solutrean and Magdalenian.

Figure 8. Selected high resolution terrestrial and marine records compared with the NGRIP curve and radiocarbon dates in the MIS-2.

Figure 9. Evolution of the number of archaeological sites, radiocarbon dates and archaeological layers of the Gravettian, Solutrean and Magdalenian technocomplexes.

Table 1. Radiocarbon dates (AMS $\mathrm{C}^{14}$ dating) from the peat bog of Verdeospesoa calibrated using Calib Radiocarbon Calibration program 7.1. The maximum probability interval is used to construct the age-depth model at $2 \sigma$ ranges. 
Supplementary Data. Appendix A. Appendix A. Supplementary data. Radiocarbon dates of the archaeological sites mentioned in the text and with standard deviations < 350 years. GRA: Gravettian, SOL: Solutrean: MG: Magdalenian. Material: B: Bone, CH: Charcoal, S: Shell, T: Teeth, OS: Organic Sediment.

\begin{tabular}{|c|c|c|c|c|c|}
\hline $\mathbf{N}^{\circ}$. & Site & Complex & Layer & Lab. Code & Material \\
\hline \multirow[t]{4}{*}{1} & Abauntz & MGD & E & Ly 1965 & B \\
\hline & Abauntz & MGD & $\mathrm{E}$ & OxA-5983 & B \\
\hline & Abauntz & MGD & $2 \mathrm{r}$ & Cams-9918 & $\mathrm{CH}$ \\
\hline & Abauntz & MGD & $2 \mathrm{r}$ & OxA-5116 & $\mathrm{CH}$ \\
\hline 2 & Abrigo de Ángel 1 & GRA & $10 \mathrm{inf}$. & GrA-16961 & $\mathrm{CH}$ \\
\hline 3 & Abrigo del Cuco & GRA & III & GrA-32097 & B \\
\hline \multirow[t]{4}{*}{4} & Aitzbitarte III & GRA & III & Ua-11147 & B \\
\hline & Aitzbitarte III & GRA & IV & UA-25965 & B \\
\hline & Aitzbitarte III & GRA & II & Ua-37959 & B \\
\hline & Aitzbitarte III & GRA & III & UA-11150 & $\mathrm{B}$ \\
\hline 5 & Aitzbitarte IV & SOL & III & GrN-5993 & B \\
\hline \multirow[t]{2}{*}{6} & Alecrim & GRA & 6 & Wk-25514 & B \\
\hline & Alecrim & GRA & 6 & Beta-203513 & B \\
\hline 7 & Alexandre & MGD & IIIb & GrN-123448 & $\mathrm{CH}$ \\
\hline \multirow[t]{2}{*}{8} & Alonsé & MGD & $\mathrm{m}$ & GrA-21536 & $\mathrm{CH}$ \\
\hline & Alonsé & MGD & $\mathrm{m}$ & GrA-21537 & $\mathrm{CH}$ \\
\hline \multirow[t]{8}{*}{9} & Altamira & GRA & 8 & GrA-27739 & B \\
\hline & Altamira & GRA & 8 & GrA-32765 & B \\
\hline & Altamira & SOL & 7 & GrA-32761 & B \\
\hline & Altamira & SOL & 7 med. & GrA-30325 & B \\
\hline & Altamira & SOL & 7 sup. & GrA-30324 & B \\
\hline & Altamira & SOL & 3 & GifA-90045 & B \\
\hline & Altamira & MGD & MG inf & I-12012 & $\mathrm{CH}$ \\
\hline & Altamira & MGD & MG (sup) & GifA-90047 & B \\
\hline \multirow[t]{2}{*}{10} & Anecrial & GRA & $3 n$ & GrA-12016 & $\mathrm{CH}$ \\
\hline & Anecrial & GRA & $2 b$ & OxA-11235 & B (Capra) \\
\hline
\end{tabular}

\begin{tabular}{llll} 
Age $(\mathbf{C}-14$ years BP) & Age $($ cal BP) & Med. Prob. & References \\
$15800 \pm 350$ & $19948-18348$ & 19111 & Utrilla et al., 2015 \\
$13500 \pm 160$ & $16776-15798$ & 16265 & Utrilla et al., 2015 \\
$12340 \pm 60$ & $14718-14088$ & 14348 & Utrilla et al., 2015 \\
$11760 \pm 90$ & $13763-13431$ & 13591 & Utrilla et al., 2015 \\
$25330 \pm 190$ & $29938-28869$ & 29391 & Utrilla \& Domingo, 2002 \\
$23400 \pm 250$ & $27968-27193$ & 27593 & Rasines \& Muñoz, 2012 \\
$20405 \pm 130$ & $27134-26310$ & 26729 & Altuna et al., 2011 \\
$22420 \pm 290$ & $27310-26078$ & 26710 & Altuna et al., 2011 \\
$19765 \pm 220$ & $24318-23219$ & 23790 & Altuna et al., 2011 \\
$18400 \pm 215$ & $22735-21745$ & 22239 & Altuna et al., 2011 \\
$17950 \pm 150$ & $22191-21315$ & 21738 & Altuna, 1972 \\
$21794 \pm 170$ & $26415-25736$ & 26032 & Bicho et al., 2012 \\
$20510 \pm 150$ & $25175-24271$ & 24703 & Bicho et al., 2012 \\
$15370 \pm 110$ & $18853-18384$ & 18638 & Utrilla et al., 2006 \\
$15069 \pm 90$ & $18558-18045$ & 18311 & Montes, 2005 \\
$14840 \pm 90$ & $18308-17828$ & 18053 & Utrilla \& Montes, 2007 \\
$21930 \pm 100$ & $26415-25917$ & 26132 & Lasheras et al., 2012 \\
$21910 \pm 90$ & $26370-25912$ & 26110 & Lasheras et al., 2012 \\
$19630 \pm 80$ & $23926-23387$ & 23652 & Lasheras et al., 2012 \\
$19060 \pm 90$ & $23298-22636$ & 22950 & Lasheras et al., 2012 \\
$18750 \pm 100$ & $22885-22403$ & 22611 & Lasheras et al., 2012 \\
$18540 \pm 320$ & $23141-21613$ & 22395 & Soto-Barreiro, 2001 \\
$15910 \pm 230$ & $19766-1814$ & 19212 & González-Sainz, 1989 \\
$14520 \pm 260$ & $18320-16984$ & 17666 & González-Echegaray, 1996 \\
$24410 \pm 110$ & $28735-28149$ & 28463 & Bicho et al., 2012 \\
$23410 \pm 170$ & $27844-27374$ & 27601 & Bicho et al., 2012 \\
& & & \\
\hline 100 & 250 & &
\end{tabular}




\begin{tabular}{|c|c|c|c|c|c|c|c|c|c|}
\hline & Anecrial & SOL & 1 & GrA-1219 & $\mathrm{CH}$ & $20520 \pm 100$ & $25087-24360$ & 24706 & Almeida et al., 2007 \\
\hline \multirow[t]{8}{*}{11} & Antoliñako Koba & GRA & Lmbk sup/Smbk & Beta-230279 & B & $27520 \pm 190$ & $31629-31053$ & 31326 & Aguirre, 2012 \\
\hline & Antoliñako Koba & GRA & Lmbk sup/Smbk & Beta-215542 & B & $26080 \pm 200$ & $30820-29746$ & 30359 & Aguirre, 2012 \\
\hline & Antoliñako Koba & GRA & $\mathrm{Lab}$ & Beta-233766 & B & $22640 \pm 120$ & $27303-26578$ & 26973 & Aguirre, 2012 \\
\hline & Antoliñako Koba & SOL & Lmc & GrN-23785 & B & $19280 \pm 120$ & $23560-22899$ & 23225 & Aguirre, 2012 \\
\hline & Antoliñako Koba & SOL & $\mathrm{Lmc}$ & Beta-230284 & B & $19020 \pm 120$ & $23282-22543$ & 22897 & Aguirre, 2012 \\
\hline & Antoliñako Koba & SOL & $\mathrm{Lmb}$ & Beta-251301 & B & $17340 \pm 100$ & $21244-20625$ & 20918 & Aguirre, 2012 \\
\hline & Antoliñako Koba & MGD & Lgc inf & GrN-23783 & B & $14680 \pm 80$ & $18077-17631$ & 17865 & Aguirre, 2012 \\
\hline & Antoliñako Koba & MGD & Lgc inf & Beta-230281 & B & $14580 \pm 70$ & $17963-17557$ & 17760 & Aguirre, 2012 \\
\hline \multirow[t]{6}{*}{12} & Arbreda & GRA & $\mathrm{D}$ & GrA-47323 & B & $22630 \pm 100$ & $27274-26595$ & 26967 & Soler et al., 2012 \\
\hline & Arbreda & GRA & $\mathrm{E}$ & Gif-6420 & $\mathrm{CH}$ & $20130 \pm 220$ & $24868-23658$ & 24209 & Delibrias et al., 1987 \\
\hline & Arbreda & SOL & $\mathrm{C}$ & GrA-47330 & B & $19480 \pm 80$ & $23726-23130$ & 23469 & Soler et al., 2012 \\
\hline & Arbreda & SOL & B & GrA-47320 & B & $18860 \pm 80$ & $22957-22486$ & 22716 & Soler et al., 2012 \\
\hline & Arbreda & SOL & $\mathrm{C}$ & Gif-6419 & B & $17720 \pm 290$ & $22187-20677$ & 21428 & Delibrias et al., 1987 \\
\hline & Arbreda & SOL & B & Gif-6418 & $\mathrm{CH}$ & $17320 \pm 290$ & $21705-20182$ & 20923 & Delibrias et al., 1987 \\
\hline 13 & Arlanpe & SOL & III & Beta-238178 & B & $17060 \pm 80$ & $20827-20328$ & 20578 & Ríos et al., 2008 \\
\hline \multirow[t]{2}{*}{14} & Askondo & GRA & - & Beta-303671 & B & $23760 \pm 110$ & $28049-27622$ & 27823 & Ríos \& Gárate, 2012 \\
\hline & Askondo & SOL & 4 & Beta-316473 & B & $17490 \pm 90$ & $21432-20836$ & 21127 & Ríos\& Gárate, 2012 \\
\hline \multirow[t]{9}{*}{15} & Atxoste & MGD & $\mathrm{h} 2$ & GrA-19503 & B & $12540 \pm 80$ & $15139-14312$ & 14808 & Utrilla et al., 2010 \\
\hline & Atxoste & MGD & $\mathrm{g}$ & GrA-19502 & B & $12200 \pm 90$ & $14491-13733$ & 14097 & Utrilla et al., 2010 \\
\hline & Atxoste & MGD & $\mathrm{f} 2$ & GrA-19554 & B & $12070 \pm 60$ & $14086-13762$ & 13917 & Utrilla et al., 2010 \\
\hline & Atxoste & MGD & $\mathrm{f}$ & GrN-26667 & B & $11960 \pm 180$ & $14331-13393$ & 13825 & Utrilla et al., 2010 \\
\hline & Atxoste & MGD & $\mathrm{f}$ & GrN-26666 & B & $11910 \pm 170$ & $14171-13398$ & 13758 & Utrilla et al., 2010 \\
\hline & Atxoste & MGD & VIIc & GrA-22900 & B & $11800 \pm 60$ & $13749-13482$ & 13633 & Utrilla et al., 2010 \\
\hline & Atxoste & MGD & $\mathrm{h}$ & GrA-19870 & B & $11730 \pm 80$ & $13744-13423$ & 13554 & Utrilla et al., 2010 \\
\hline & Atxoste & MGD & VIIb & GrA-22865 & B & $11720 \pm 70$ & $13729-13428$ & 13541 & Utrilla et al., 2010 \\
\hline & Atxoste & MGD & VIIc & GrA-23107 & B & $11690 \pm 80$ & $13729-13365$ & 13518 & Utrilla et al., 2010 \\
\hline \multirow[t]{2}{*}{16} & Balma Gai & MGD & I & Gif-956330 & - & $12240 \pm 110$ & $14713-13795$ & 14189 & García-Arguelles et al., 2001 \\
\hline & Balma Gai & MGD & II & GifA-10029 & - & $11170 \pm 160$ & $13302-12725$ & 13021 & García-Arguelles et al., 2001 \\
\hline 17 & Balma Griera & GRA & III & AA-8649 & B & $21255 \pm 350$ & $26149-24589$ & 25529 & Fullola et al., 1994 \\
\hline \multirow[t]{2}{*}{18} & Balma Guilanyà & MGD & $\mathrm{Ej}$ & Beta-185066 & $\mathrm{CH}$ & $12180 \pm 50$ & $14228-13870$ & 14069 & Casanova et al., 2006 \\
\hline & Balma Guilanyà & MGD & $\mathrm{Ej}$ & UBAR-367 & $\mathrm{CH}$ & $11460 \pm 230$ & $13749-12829$ & 13305 & Casanova et al., 2006 \\
\hline
\end{tabular}




\begin{tabular}{|c|c|c|c|c|c|c|c|c|c|}
\hline \multirow[t]{2}{*}{19} & Berroberria & MGD & D inf & OxA-949 & - & $11900 \pm 130$ & $14050-13464$ & 13733 & Barandiarán, 1990 \\
\hline & Berroberria & MGD & D inf & OxA-978 & B & $11600 \pm 130$ & $13725-13184$ & 13429 & Barandiarán, 1990 \\
\hline \multirow[t]{2}{*}{20} & Bora Gran & MGD & - & OxBGA-2153 & B & $13080 \pm 90$ & 15974-15331 & 15675 & Nadal, 1998 \\
\hline & Bora Gran & MGD & - & OxBga-2222 & $\mathrm{B}$ & $12830 \pm 80$ & $15620-15077$ & 15305 & Nadal, 1998 \\
\hline \multirow[t]{2}{*}{21} & Buendía & MGD & $\mathrm{N} 1 \mathrm{C}$ & Beta-212776 & $\mathrm{CH}$ & $14840 \pm 50$ & $18226-17875$ & 18044 & Cacho et al., 2012 \\
\hline & Buendía & MGD & - & UtC-4006 & $\mathrm{CH}$ & $14380 \pm 90$ & $17817-17228$ & 17526 & Cacho et al., 2012 \\
\hline \multirow[t]{2}{*}{22} & Buraca Escura & GRA & 3 & OzA-5523 & B & $22700 \pm 240$ & $27481-26423$ & 26998 & Bicho et al., 2012 \\
\hline & Buraca Escura & GRA & 2 & OxA-5524 & B & $21820 \pm 200$ & $26512-25714$ & 26063 & Bicho et al., 2012 \\
\hline \multirow[t]{4}{*}{23} & Buraca Grande & GRA & $9 \mathrm{~B}$ & GifA-93048 & $\mathrm{CH}$ & $23920 \pm 300$ & $28602-27546$ & 28021 & Bicho et al., 2012 \\
\hline & Buraca Grande & SOL & 9 & Gif-9502 & $\mathrm{CH}$ & $17850 \pm 200$ & $22151-21024$ & 21603 & Aubry et al., 2001 \\
\hline & Buraca Grande & MGD & - & OxA-5522 & B & $13050 \pm 100$ & $15953-15286$ & 15626 & Bicho and Haws, 2012 \\
\hline & Buraca Grande & MGD & 2 & GifA-96307 & B & $11390 \pm 110$ & $13444-13065$ & 13237 & Bicho and Haws, 2012 \\
\hline \multirow[t]{12}{*}{24} & Cabeço do Porto Marinho & SOL & III inferior & SMU-2475 & $\mathrm{CH}$ & $22710 \pm 350$ & $27591-26208$ & 26969 & Bicho et al., 2012 \\
\hline & Cabeço do Porto Marinho & MGD & 5 & Wk-3126 & $\mathrm{CH}$ & $16180 \pm 290$ & $20203-18853$ & 19523 & Bicho and Haws, 2012 \\
\hline & Cabeço do Porto Marinho & MGD & 9 & SMU-2634 & $\mathrm{CH}$ & $15420 \pm 180$ & $19055-18264$ & 18676 & Bicho and Haws, 2012 \\
\hline & Cabeço do Porto Marinho & MGD & 8 & SMU-2476 & $\mathrm{CH}$ & $15410 \pm 195$ & $19082-18202$ & 18664 & Bicho and Haws, 2012 \\
\hline & Cabeço do Porto Marinho & MGD & 9 & Wk-3127 & $\mathrm{CH}$ & $15040 \pm 210$ & $18739-17817$ & 18274 & Bicho and Haws, 2012 \\
\hline & Cabeço do Porto Marinho & MGD & 13 & ICEN-687 & $\mathrm{CH}$ & $12220 \pm 110$ & $14666-13778$ & 14148 & Bicho and Haws, 2012 \\
\hline & Cabeço do Porto Marinho & MGD & 12 & ICEN-689 & $\mathrm{CH}$ & $11810 \pm 110$ & 13944-13889 & 13638 & Bicho and Haws, 2012 \\
\hline & Cabeço do Porto Marinho & MGD & 13 & SMU-2011 & $\mathrm{CH}$ & $11680 \pm 60$ & $13708-13675$ & 13509 & Bicho and Haws, 2012 \\
\hline & Cabeço do Porto Marinho & MGD & 14 & ICEN-545 & $\mathrm{CH}$ & $11160 \pm 280$ & $13575-12546$ & 13029 & Bicho and Haws, 2012 \\
\hline & Cabeço do Porto Marinho & MGD & 15 & SMU-2637 & $\mathrm{CH}$ & $11110 \pm 130$ & $13194-12723$ & 12961 & Bicho and Haws, 2012 \\
\hline & Cabeço do Porto Marinho & MGD & 16 & ICEN-690 & $\mathrm{CH}$ & $10940 \pm 210$ & $13259-12516$ & 12851 & Bicho and Haws, 2012 \\
\hline & Cabeço do Porto Marinho & MGD & 17 & SMU-2636 & $\mathrm{CH}$ & $10160 \pm 80$ & $12098-11403$ & 11816 & Bicho and Haws, 2012 \\
\hline \multirow[t]{4}{*}{25} & Caldeirao & GRA & $\mathrm{Jb}$ & OxA-5542 & $\mathrm{B}$ & $26020 \pm 320$ & $30886-29484$ & 30235 & Bicho et al., 2012 \\
\hline & Caldeirao & SOL & $\mathrm{H}$ & OxA-2511 & $\mathrm{B}$ & $20530 \pm 270$ & $25414-24054$ & 24732 & Zilhão, 2000 \\
\hline & Caldeirao & SOL & $\mathrm{H}$ & OxA-1939 & B (Capra pyrenaica) & $19900 \pm 260$ & $24561-23258$ & 23941 & Zilhão 2000 \\
\hline & Caldeirao & SOL & $\mathrm{Fc}$ & OxA-2510 & B & $18840 \pm 200$ & $23242-22325$ & 22723 & Zilhão, 1997 \\
\hline 26 & Casa da Moura & GRA & $1 \mathrm{~b}$ & TO-1102 & B (Canis lupus) & $25900 \pm 220$ & $30705-29535$ & 30132 & Straus et al., 1998 \\
\hline \multirow[t]{3}{*}{27} & Cendres & GRA & XVIc & Beta-189078 & $\mathrm{CH}$ (P. nigra) & $25850 \pm 260$ & $30721-29426$ & 30071 & Villaverde \& Román, 2012 \\
\hline & Cendres & GRA & XVIc & Beta-287537 & $\mathrm{CH}$ & $25500 \pm 140$ & $30143-29202$ & 29605 & Villaverde \& Román, 2012 \\
\hline & Cendres & GRA & XVIa & Beta-142283 & $\mathrm{CH}$ (P. nigra) & $24240 \pm 220$ & $28710-27828$ & 28272 & Villaverde \& Román, 2012 \\
\hline
\end{tabular}




\begin{tabular}{|c|c|c|c|c|c|c|c|c|c|}
\hline & Cendres & GRA & $\mathrm{XV}$ & Beta-303419 & $\mathrm{CH}$ & $23350 \pm 100$ & 27752-27381 & 27570 & Villaverde \& Román, 2012 \\
\hline & Cendres & GRA & XVIa & Beta-287549 & $\mathrm{CH}$ & $21860 \pm 100$ & 26326-25869 & 26069 & Villaverde \& Román, 2012 \\
\hline & Cendres & GRA & XIV & Beta-142282 & $\mathrm{CH}$ & $21230 \pm 80$ & $25787-25327$ & 25584 & Villaverde \& Román, 2004 \\
\hline & Cendres & GRA & XIV & Beta-287546 & $\mathrm{CH}$ & $20800 \pm 110$ & 25422-24616 & 25092 & Villaverde \& Román, 2012 \\
\hline & Cendres & SOL & XIIIlb & Beta-118026 & $\mathrm{CH}$ & $18920 \pm 180$ & 23272-22417 & 22794 & Villaverde et al., 1999 \\
\hline & Cendres & SOL & XIIIb & Beta-118027 & $\mathrm{CH}$ & $18750 \pm 130$ & 22940-22374 & 22622 & Villaverde et al., 1999 \\
\hline & Cendres & SOL & XIIb & Beta-118024 & $\mathrm{CH}$ (P. nigra) & $17230 \pm 130$ & 21166-20446 & 20784 & Villaverde et al., 1999 \\
\hline & Cendres & MGD & XII & Beta-287541 & $\mathrm{CH}$ & $16030 \pm 60$ & 19554-19150 & 19352 & Villaverde et al., 2012 \\
\hline & Cendres & MGD & XII & Beta-287840 & $\mathrm{CH}$ & $15630 \pm 60$ & 19011-18739 & 18871 & Villaverde et al., 2012 \\
\hline & Cendres & MGD & XIIa & Beta-118023 & $\mathrm{CH}$ & $14850 \pm 100$ & $18337-17821$ & 18066 & Villaverde et al., 1999 \\
\hline 28 & Chaves & SOL & $\mathrm{C} 1$ & GrN-12681 & $\mathrm{CH}$ & $19700 \pm 310$ & 24422-22947 & 23947 & Utrilla et al., 2010 \\
\hline & Chaves & MGD & $2 \mathrm{~b}$ & GrN-15635 & B & $12950 \pm 70$ & 15741-15239 & 15381 & Utrilla et al., 2010 \\
\hline & Chaves & MGD & $2 \mathrm{~b}$ & GrN-14561 & B & $12660 \pm 70$ & $15283-14730$ & 15054 & Utrilla et al., 2010 \\
\hline & Chaves & MGD & $2 a$ & GrN-12682 & $\mathrm{CH}$ & $12020 \pm 350$ & $15128-13198$ & 14014 & Utrilla et al., 2010 \\
\hline 29 & Cobrante & SOL & 3 & GrA-22438 & B & $18540 \pm 70$ & $22579-22259$ & 22419 & Rasines, 2009 \\
\hline & Cobrante & SOL & 4 & GrA-22439 & B & $18260 \pm 70$ & $22347-21892$ & 22129 & Rasines, 2009 \\
\hline 30 & Colls & MGD & IV & GifA-95571 & $\mathrm{CH}$ & $12490 \pm 120$ & $15132-14171$ & 14673 & Fullola et al., 2012 \\
\hline & Colls & MGD & IV & GifA-95544 & $\mathrm{CH}$ & $12150 \pm 120$ & 14563-13730 & 14033 & Casanova et al., 2006 \\
\hline & Colls & MGD & II & AA-8645 & $\mathrm{CH}$ & $10950 \pm 120$ & 13064-12691 & 12850 & Bergadá, 1998 \\
\hline 31 & Cova Gran Sta. Linya & MGD & EA-3 & Beta-233606 & $\mathrm{CH}$ & $16800 \pm 80$ & 20502-20030 & 20265 & Mora et al., 2011 \\
\hline & Cova Gran Sta. Linya & MGD & $6 \mathrm{P}$ & Beta-265984 & $\mathrm{CH}$ & $15120 \pm 70$ & 18580-18149 & 18380 & Mora et al., 2011 \\
\hline & Cova Gran Sta. Linya & MGD & $4 \mathrm{P}$ & Beta-259273 & $\mathrm{CH}$ & $14760 \pm 70$ & 18168-17739 & 17960 & Mora et al., 2011 \\
\hline & Cova Gran Sta. Linya & MGD & $\mathrm{S} 4 \mathrm{H}$ & Beta-187424 & $\mathrm{CH}$ & $13660 \pm 50$ & $16712-16249$ & 16466 & Fullola et al., 2012 \\
\hline 32 & Cualventí & MGD & E & GrA-21431 & $\mathrm{CH}$ & $15950 \pm 70$ & 19483-19012 & 19242 & Uzquiano, 2014 \\
\hline 33 & Cueto de la Mina & SOL & $\mathrm{V}$ & Ua-3586 & B & $19110 \pm 205$ & $23521-22521$ & 23023 & Rasilla \& Lana, 1994 \\
\hline & Cueto de la Mina & SOL & F & Ua-3588 & B & $17545 \pm 205$ & $21777-20668$ & 21209 & Soto-Barreiro 2003 \\
\hline & Cueto de la Mina & MGD & B & OxA-996 & B (Antler) & $11650 \pm 190$ & 13932-13092 & 13488 & Soto-Barreiros, 2013 \\
\hline & Cueto de la Mina & MGD & B & OxA-969 & B (Antler) & $11630 \pm 120$ & $13737-13243$ & 13460 & Soto-Barreiros, 2013 \\
\hline 34 & Cueva Ambrosio & SOL & IV & Gif-9884 & $\mathrm{CH}$ & $21520 \pm 120$ & $26030-25596$ & 25820 & Ripoll et al., 2006 \\
\hline & Cueva Ambrosio & SOL & II.1 & GifA-95576 & $\mathrm{CH}$ & $20150 \pm 200$ & 24838-23722 & 24228 & Ripoll et al., 2006 \\
\hline & Cueva Ambrosio & SOL & II.1 & GifA-95577 & $\mathrm{CH}$ & $19950 \pm 210$ & 24492-23489 & 24000 & Ripoll et al., 2006 \\
\hline & Cueva Ambrosio & SOL & II.6 & Gif-A-II.6 & $\mathrm{CH}$ & $19300 \pm 190$ & $23741-22751$ & 23246 & Jordá et al., 2012 \\
\hline
\end{tabular}




\begin{tabular}{|c|c|c|c|c|c|c|c|c|c|}
\hline & Cueva Ambrosio & SOL & II.g & Gif-9883 & $\mathrm{CH}$ & $19250 \pm 70$ & $23462-22932$ & 23192 & Ripoll et al., 2006 \\
\hline & Cueva Ambrosio & $\mathrm{SOL}$ & II. 2 & GifA-A-II.2 & $\mathrm{CH}$ & $19170 \pm 190$ & $23566-22592$ & 23097 & Jordá et al., 2012 \\
\hline & Cueva Ambrosio & SOL & II. 4 & Gif-A-II.4 & $\mathrm{CH}$ & $19110 \pm 90$ & $23378-22731$ & 23018 & Jordá et al., 2012 \\
\hline & Cueva Ambrosio & SOL & II & Gif-7276 & $\mathrm{CH}$ & $16500 \pm 280$ & 20584-19207 & 19907 & Ripoll, 1988 \\
\hline \multirow[t]{3}{*}{35} & Cueva Beneito & SOL & IV (ext) & Ua-32244 & $\mathrm{B}$ & $18275 \pm 175$ & $22485-21713$ & 22128 & Domenech et al., 2012 \\
\hline & Cueva Beneito & SOL & B2 & Ly-3594 & - & $16560 \pm 280$ & 20650-19269 & 19980 & Cascalheira, 2013 \\
\hline & Cueva Beneito & SOL & II (ext) & Ua-32243 & $\mathrm{B}$ & $16180 \pm 140$ & 19930-19148 & 19524 & Domenech et al., 2012 \\
\hline \multirow[t]{2}{*}{36} & Cueva del Gato & SOL & 2 & GrA-22505 & $\mathrm{CH}$ & $18650 \pm 140$ & $22900-22237$ & 22524 & Blasco \& Rodanés, 2004 \\
\hline & Cueva del Gato & SOL & 2 & GrA-42226 & B & $17700 \pm 70$ & $21702-21130$ & 21423 & Blasco \& Rodanés, 2004 \\
\hline 37 & Cueva del Ruso & SOL & IV & Beta- 810 & $\mathrm{~B}$ & $16410 \pm 210$ & 20326-19255 & 19802 & Yravedra et al., 2010 \\
\hline 38 & Cueva Eiros & MGD & B & Beta-308859 & - & $12060 \pm 50$ & $14063-13763$ & 13904 & Fabregas et al., 2010 \\
\hline 39 & Cueva Morín & GRA & $5 \mathrm{a}$ & Si-953 & $\mathrm{CH}$ & $20107 \pm 350$ & $25179-23380$ & 24206 & González-Echegaray \& Freeman, 1978 \\
\hline 40 & Cueva Oscura & MGD & $3 a$ & Gif-5106 & - & $11670 \pm 200$ & $13956-13112$ & 13510 & Adán et al., 2005 \\
\hline \multirow[t]{5}{*}{41} & Ekain & MGD & VIIb & $\mathrm{I}-12020$ & $\mathrm{~B}$ & $16510 \pm 270$ & 20571-19240 & 19919 & Altuna \& Merino, 1984 \\
\hline & Ekain & MGD & VIIb & $\mathrm{I}-12224$ & $\mathrm{~B}$ & $16030 \pm 240$ & 19934-18818 & 19344 & Altuna \& Merino, 1984 \\
\hline & Ekain & MGD & VIIc & $\mathrm{I}-12225$ & $\mathrm{~B}$ & $15970 \pm 240$ & $19869-18763$ & 19278 & Altuna \& Merino, 1984 \\
\hline & Ekain & MGD & VIId & I-12266 & $\mathrm{B}$ & $15400 \pm 240$ & 19181-18081 & 18650 & Altuna \& Merino, 1984 \\
\hline & Ekain & MGD & VI & I-9240 & - & $12050 \pm 190$ & $14652-13466$ & 13941 & Altuna \& Merino, 1984 \\
\hline \multirow[t]{10}{*}{42} & El Castillo & GRA & 14 & Beta-298432 & B & $29740 \pm 190$ & $34202-33554$ & 33875 & Bernaldo de Quirós et al., 2012 \\
\hline & El Castillo & GRA & 14 & Beta-298433 & $\mathrm{B}$ & $29600 \pm 180$ & $34094-33454$ & 33777 & Bernaldo de Quirós et al., 2012 \\
\hline & El Castillo & GRA & 12 & Beta-298430 & $\mathrm{B}$ & $25920 \pm 140$ & $30604-29681$ & 30170 & Bernaldo de Quirós et al., 2012 \\
\hline & El Castillo & GRA & 12 & Beta-242617 & B & $24070 \pm 150$ & $28483-27782$ & 28108 & Bernaldo de Quirós et al., 2012 \\
\hline & El Castillo & SOL & 10 & Beta-242619 & B & $19260 \pm 90$ & $23494-22927$ & 23204 & Bernaldo de Quirós et al., 2012b \\
\hline & El Castillo & $\mathrm{SOL}$ & 10 & OxA-971 & B & $16850 \pm 220$ & 20882-19768 & 20327 & Sommer et al., 2008 \\
\hline & El Castillo & MGD & 8 & OxA-971 & $\mathrm{B}$ & $16850 \pm 220$ & 20882-19768 & 20327 & Barandiarán, 1988 \\
\hline & El Castillo & MGD & 8 & Beta-242620 & $\mathrm{B}$ & $15160 \pm 70$ & $18620-18216$ & 18427 & Bernaldo de Quirós et al., 2012b \\
\hline & El Castillo & MGD & 6 & - & B & $12390 \pm 120$ & $15039-14072$ & 14500 & Barandiarán, 1988 \\
\hline & El Castillo & MGD & 6 & - & $\mathrm{B}$ & $10310 \pm 120$ & $12548-11695$ & 12117 & Barandiarán, 1988 \\
\hline \multirow[t]{2}{*}{43} & El Horno & MGD & 1 & GX-27457 & B & $12530 \pm 190$ & $15356-14049$ & 14729 & Straus et al., 2002 \\
\hline & El Horno & MGD & 2 & GX-27456 & B & $12250 \pm 190$ & $15038-13744$ & 14285 & Straus et al., 20012 \\
\hline \multirow[t]{2}{*}{44} & El Linar & SOL & B3 & GrA-21436 & $\mathrm{B}$ & $19680 \pm 320$ & $24427-22906$ & 23686 & Uzquano, 2014 \\
\hline & El Linar & MGD & $\mathrm{C} 3$ & GrA-21435 & B & $14040 \pm 60$ & $17338-16797$ & 17062 & Uzquiano, 2014 \\
\hline
\end{tabular}




\begin{tabular}{|c|c|c|c|}
\hline El Mirón & GRA & 128 & GX-27113 \\
\hline El Mirón & SOL & 127 & UG-7216 \\
\hline El Mirón & SOL & 126 & GX-24471 \\
\hline El Mirón & SOL & 121 & GX-32655 \\
\hline El Mirón & SOL & 313 & GX-31194 \\
\hline El Mirón & MGD & 26 & GX-29439 \\
\hline El Mirón & MGD & 117 & GX-25857 \\
\hline El Mirón & MGD & 119 & GX-25857 \\
\hline El Mirón & MGD & Niche A & GX-30398 \\
\hline El Mirón & MGD & 114 & GX-28209 \\
\hline El Mirón & MGD & 111 & GX-23395 \\
\hline El Mirón & MGD & 119.2 & GX-32656 \\
\hline El Mirón & MGD & 110 & GX-23396 \\
\hline El Mirón & MGD & 18 & UG-3366R \\
\hline El Mirón & MGD & 21 & UG-3364R \\
\hline El Mirón & MGD & 312 & GX-31932 \\
\hline El Mirón & MGD & 17 & GX-25853 \\
\hline El Mirón & MGD & 504 & UG-7217 \\
\hline El Mirón & MGD & 20 & GX-24469 \\
\hline El Mirón & MGD & 118 & GX-31933 \\
\hline El Mirón & MGD & 26 & OxA-22090 \\
\hline El Mirón & MGD & 17 & GX-32654 \\
\hline El Mirón & MGD & 116 & GX-23416 \\
\hline El Mirón & MGD & 16 & GX-234115 \\
\hline El Mirón & MGD & 503.1 & UG-7799 \\
\hline El Mirón & MGD & 15 & GX-23392 \\
\hline El Mirón & MGD & 13 & OxA-22089 \\
\hline El Mirón & MGD & 108 & GX-27114 \\
\hline El Mirón & MGD & 18 & OxA-22091 \\
\hline El Mirón & MGD & 5 & GX-23397 \\
\hline El Mirón & MGD & 10 & GX-22347 \\
\hline El Mirón & MGD & 10 & GX32381 \\
\hline
\end{tabular}

$\begin{array}{lll}27580 \pm 210 & 31757-31058 & 31368 \\ 19230 \pm 50 & 23426-22942 & 23168 \\ 18950 \pm 350 & 23694-22064 & 22864 \\ 18390 \pm 300 & 22923-21505 & 22220 \\ 17400 \pm 270 & 21769-20349 & 21026 \\ 17400 \pm 80 & 21288-20733 & 20998 \\ 17050 \pm 60 & 20767-20354 & 20566 \\ 16960 \pm 80 & 20683-20194 & 20455 \\ 16600 \pm 90 & 20300-19738 & 20029 \\ 16460 \pm 50 & 20052-19647 & 19860 \\ 16370 \pm 190 & 20220-19250 & 19758 \\ 16320 \pm 160 & 20090-19268 & 19704 \\ 16130 \pm 250 & 20053-18886 & 19460 \\ 16080 \pm 40 & 19568-19239 & 19415 \\ 16050 \pm 40 & 19543-19212 & 19378 \\ 15850 \pm 170 & 19547-18778 & 19136 \\ 15700 \pm 190 & 19454-18588 & 18976 \\ 15740 \pm 40 & 19125-18864 & 18975 \\ 15530 \pm 230 & 19361-18285 & 18793 \\ 15460 \pm 190 & 19148-18298 & 18717 \\ 15430 \pm 75 & 18853-18534 & 18698 \\ 15350 \pm 80 & 18794-18430 & 18625 \\ 15220 \pm 100 & 18725-18234 & 18485 \\ 15180 \pm 100 & 18684-18166 & 18444 \\ 15120 \pm 40 & 18544-18217 & 18383 \\ 15010 \pm 260 & 18783-17649 & 18239 \\ 14930 \pm 70 & 18348-17939 & 18148 \\ 14850 \pm 60 & 18257-17877 & 18057 \\ 14760 \pm 70 & 18168-17739 & 17960 \\ 14710 \pm 160 & 18302-17517 & 17900 \\ 14620 \pm 80 & 18008-17577 & 17798 \\ 13710 \pm 70 & 16850-16285 & 16549\end{array}$

González-Morales \& Straus, 2012 González-Morales \& Straus, 2012 González-Morales \& Straus, 2012 González-Morales \& Straus, 2012 González-Morales \& Straus, 2012 González-Morales \& Straus, 2012 González-Morales \& Straus, 2012 González-Morales \& Straus, 2012 González-Morales \& Straus, 2012 González-Morales \& Straus, 2012 González-Morales \& Straus, 2012 González-Morales \& Straus, 2012 González-Morales \& Straus, 2012 González-Morales \& Straus, 2012 González-Morales \& Straus, 2012 González-Morales \& Straus, 2012 González-Morales \& Straus, 2012 González-Morales \& Straus, 2012 González-Morales \& Straus, 2012 González-Morales \& Straus, 2012 González-Morales \& Straus, 2012 González-Morales \& Straus, 2012 González-Morales \& Straus, 2012 González-Morales \& Straus, 2012 González-Morales \& Straus, 2012 González-Morales \& Straus, 2012 González-Morales \& Straus, 2012 González-Morales \& Straus, 2012 González-Morales \& Straus, 2012 González-Morales \& Straus, 2012 González-Morales \& Straus, 2012 González-Morales \& Straus, 2012 


\begin{tabular}{|c|c|c|c|c|c|c|c|c|c|}
\hline & El Mirón & MGD & 4 & GX-22703 & B & $13660 \pm 70$ & $16768-16228$ & 16471 & González-Morales \& Straus, 2012 \\
\hline & El Mirón & MGD & 7 & UG-9286 & B & $13490 \pm 70$ & $16508-16011$ & 16239 & González-Morales \& Straus, 2012 \\
\hline & El Mirón & MGD & 12 & GX-22132 & $\mathrm{CH}$ & $12970 \pm 70$ & $15764-15259$ & 15508 & González-Morales \& Straus, 2012 \\
\hline & El Mirón & MGD & 16 & GX-28210 & $\mathrm{CH}$ & $12350 \pm 180$ & $15105-13847$ & 14458 & González-Morales \& Straus, 2012 \\
\hline \multirow[t]{2}{*}{46} & El Monte & MGD & - & Beta-245814 & - & $14660 \pm 80$ & $18051-17612$ & 17841 & Cacho et al., 2012 \\
\hline & El Monte & MGD & - & Beta-245813 & - & $13570 \pm 70$ & $16623-16120$ & 16350 & Cacho et al., 2012 \\
\hline \multirow[t]{3}{*}{47} & El Palomar & GRA & IV & Beta- 85410 & B & $26430 \pm 210$ & $31057-30240$ & 30708 & Peña \& Vega, 2012 \\
\hline & El Palomar & GRA & $\mathrm{V}$ & Beta-185411 & B & $26230 \pm 200$ & 30930-29918 & 30525 & Peña \& Vega, 2012 \\
\hline & El Palomar & GRA & III & Beta-185409 & B & $21560 \pm 110$ & $26045-25646$ & 25850 & Peña \& Vega, 2012 \\
\hline 48 & El Pendo & MGD & II & OxA-977 & B & $14830 \pm 130$ & 18264-17709 & 18047 & Barandiarán, 1988 \\
\hline 49 & Entrefoces & MGD & $\mathrm{B}$ & Ly-2937 & B & $14690 \pm 200$ & $18373-17393$ & 17875 & González-Morales, 1990 \\
\hline \multirow[t]{3}{*}{50} & Erralla & MGD & $\mathrm{Va}$ & $\mathrm{I}-12551$ & B & $16270 \pm 240$ & 20198-19010 & 19634 & Altuna et al., 1985 \\
\hline & Erralla & MGD & $\mathrm{Va}$ & $\mathrm{I}-12540$ & B & $16030 \pm 240$ & $19934-18818$ & 19344 & Altuna et al., 1985 \\
\hline & Erralla & MGD & $\mathrm{V}$ & I- 12868 & B & $15740 \pm 240$ & $19592-18525$ & 19032 & Altuna et al., 1985 \\
\hline \multirow[t]{2}{*}{51} & Finca Doña Martina & GRA & $7 \mathrm{~b}$ & VERA-5368 & - & $26990 \pm 220$ & 31312-30795 & 31047 & Villaverde \& Román, 2012 \\
\hline & Finca Doña Martina & SOL & 04-may & VERA-510bHS & $\mathrm{CH}$ & $19180 \pm 90$ & $23435-22842$ & 23110 & Zilhao et al., 2011 \\
\hline \multirow[t]{6}{*}{52} & Forcas I & MGD & 15 & GrA-25979 & B & $14440 \pm 70$ & $17859-17385$ & 17602 & Utrilla et al., 2010 \\
\hline & Forcas I & MGD & 14 & GrN-17788 & B & $13010 \pm 320$ & $16444-14293$ & 15530 & Utrilla et al., 2010 \\
\hline & Forcas I & MGD & 14 & GrA-33986 & B & $12600 \pm 60$ & $15215-14628$ & 14955 & Utrilla et al., 2010 \\
\hline & Forcas I & MGD & $13 \mathrm{~d}$ & GrA-32957 & B & $12440 \pm 50$ & $14934-14217$ & 14561 & Utrilla et al., 2010 \\
\hline & Forcas I & MGD & $13 \mathrm{a}$ & GrA-33987 & B & $12010 \pm 60$ & $14044-13735$ & 13868 & Utrilla et al., 2010 \\
\hline & Forcas I & MGD & 10 & GrA-32959 & B & $11015 \pm 45$ & $13010-12741$ & 12879 & Utrilla \& Montes, 2008 \\
\hline 53 & Fuente del Salín & GRA & 2 & GX-27756 & $\mathrm{CH}$ & $22580 \pm 100$ & $27224-26553$ & 26906 & Cuenca, 2013 \\
\hline 54 & Fuente del Trucho & SOL & UA1 & Beta-72393 & B & $19060 \pm 80$ & $23276-22652$ & 22950 & Utrilla et al., 2010 \\
\hline \multirow[t]{2}{*}{55} & Galeria da Cisterna & MGD & 3 & GrA-11129 & B (Capra sp) & $11755 \pm 80$ & $13750-13444$ & 13583 & Trinkaus et al., 2011 \\
\hline & Galeria da Cisterna & MGD & 3 & GrA-9722 & B & $10820 \pm 60$ & $12808-12652$ & 12722 & Trinkaus et al., 2011 \\
\hline 56 & Gorhams`Cave & SOL & III & Beta-184042 & $\mathrm{CH}$ & $18440 \pm 160$ & 22611-21884 & 22291 & Finlayson et al., 2006 \\
\hline 57 & Hornos de la Peña & SOL & $\mathrm{C}$ & BM-1882R & B & $20180 \pm 310$ & 25153-23555 & 24292 & Bowman et al., 1990 \\
\hline \multirow[t]{2}{*}{58} & Hort de la Boquera & MGD & II & OxA-13595 & $\mathrm{CH}$ & $12250 \pm 60$ & $14489-13967$ & 14162 & Fullola et al., 2012 \\
\hline & Hort de la Boquera & MGD & II & OxA-23645 & $\mathrm{CH}$ & $11775 \pm 45$ & $13729-13476$ & 13603 & Fullola et al., 2012 \\
\hline 59 & Kukuma & MGD & 11 & Ua-2625 & B & $11550 \pm 130$ & $13700-13106$ & 13381 & Baldeón \& Berganza, 1997 \\
\hline 60 & La Boja & SOL & SW18E & VERA-5213 & CH (Juniperus sp.) & $20980 \pm 110$ & $25617-25031$ & 25334 & Lucena et al., 2012 \\
\hline
\end{tabular}




\begin{tabular}{|c|c|c|c|c|c|c|c|c|c|}
\hline & La Boja & SOL & SW18E & VERA-5366 & CH (Juniperus sp.) & $20980 \pm 120$ & $25637-25003$ & 25332 & Lucena et al., 2012 \\
\hline & La Boja & SOL & SW18C & VERA-5365 & $\mathrm{CH}$ (Juniperus sp.) & $19390 \pm 100$ & $23640-23022$ & 23346 & Lucena et al., 2012 \\
\hline & La Boja & SOL & SW18B2 & VERA-5364-b & $\mathrm{CH}$ (Juniperus sp.) & $17430 \pm 70$ & 21310-20801 & 21039 & Lucena et al., 2012 \\
\hline & La Boja & SOL & SW18B2 & VERA-5364-a & CH (Juniperus sp.) & $16990 \pm 70$ & $20704-20255$ & 20493 & Lucena et al., 2012 \\
\hline & La Boja & SOL & SW18B1 & VERA-5788 & $\mathrm{CH}$ & $16580 \pm 70$ & 20228-19755 & 20005 & Lucena et al., 2012 \\
\hline \multirow[t]{6}{*}{61} & La Garma A & GRA & F3 & TO-11697 & B & $22200 \pm 170$ & $26965-26038$ & 26431 & Arias et al., 2007 \\
\hline & La Garma A & MGD & 5 & OxA-7181 & B & $13860 \pm 100$ & $17111-16415$ & 16782 & Arias et al., 2000 \\
\hline & La Garma A & MGD & Zone IV & OxA-8722 & B & $13610 \pm 100$ & $16777-16105$ & 16410 & Arias et al., 2011 \\
\hline & La Garma A & MGD & 5 & OxA-7204 & $\mathrm{B}$ & $13490 \pm 110$ & $16604-15907$ & 16244 & Arias et al., 2000 \\
\hline & La Garma A & MGD & Zone IV & AA-45581 & B & $13410 \pm 120$ & $16503-15780$ & 16135 & Arias et al., 2011 \\
\hline & La Garma A & MGD & 3 & OxA-7203 & - & $12070 \pm 100$ & $14203-13711$ & 13926 & Arias et al., 2000 \\
\hline \multirow[t]{3}{*}{62} & La Paloma & MGD & 6 & OxA-974 & B & $14600 \pm 160$ & $18176-17468$ & 17771 & Barandiarán, 1988 \\
\hline & La Paloma & MGD & 4 & OxA-973 & $\mathrm{B}$ & $12860 \pm 130$ & $15803-14937$ & 15365 & Barandiarán, 1988 \\
\hline & La Paloma & MGD & 4 & OxA-975 & - & $12750 \pm 130$ & $15695-14628$ & 15178 & Barandiarán, 1988 \\
\hline \multirow[t]{2}{*}{63} & La Pila & MGD & IV.4 & Gif-90033 & $\mathrm{CH}$ & $12580 \pm 190$ & $15461-14100$ & 14812 & Uzquiano, 2014 \\
\hline & La Pila & MGD & IV.2 2 & Gif-8147 & $\mathrm{CH}$ & $12160 \pm 130$ & $14658-13732$ & 14056 & Bernaldo de Quirós \& Gutierrez, 1992 \\
\hline \multirow[t]{4}{*}{64} & La Riera & SOL & 12 & GAK-6446 & B & $17210 \pm 350$ & 21731-19940 & 20788 & Straus \& Clark, 1986 \\
\hline & La Riera & SOL & 17 & GAK-6445 & $\mathrm{CH}$ & $16900 \pm 200$ & 20900-19894 & 20384 & Straus \& Clark, 1986 \\
\hline & La Riera & MGD & 19 & Q-2116 & $\mathrm{CH}$ & $15230 \pm 300$ & $19125-17791$ & 18464 & Straus \& Clark, 1986 \\
\hline & La Riera & MGD & 23 & UCR-1274D & B & $12620 \pm 300$ & $15846-13926$ & 14873 & Straus \& Clark, 1986 \\
\hline \multirow[t]{3}{*}{65} & La Viña & SOL & IX & OxA-21688 & B (Cervus elaphus) & $24680 \pm 130$ & 29011-28401 & 28714 & Santamaria et al., 2012 \\
\hline & La Viña & MGD & IV & Ly-3316 & B & $13360 \pm 190$ & $16644-15455$ & 16067 & Santamaria et al., 2012 \\
\hline & La Viña & MGD & IV & Ly-3317 & $\mathrm{B}$ & $13300 \pm 150$ & $16434-15496$ & 15986 & Santamaria et al., 2012 \\
\hline \multirow[t]{9}{*}{66} & Lagar Velho & GRA & GC3 & OxA-9572 & B & $23170 \pm 140$ & 27693-27198 & 27455 & Zilhão \& Trinkaus 2000 \\
\hline & Lagar Velho & GRA & 1s/ms boundary & Wk-9571 & B & $23042 \pm 142$ & $27615-27082$ & 27361 & Zilhão \& Trinkaus 2000 \\
\hline & Lagar Velho & GRA & $\mathrm{GC} 4$ & Beta-139361 & B & $22720 \pm 90$ & $27352-26707$ & 27094 & Zilhão \& Trinkaus 2000 \\
\hline & Lagar Velho & GRA & us & OxA-8425 & $\mathrm{CH}$ & $22670 \pm 160$ & $27368-26548$ & 26995 & Zilhão \& Trinkaus 2000 \\
\hline & Lagar Velho & GRA & $\mathrm{ms}$ & Wk-9256 & CH (Pinus sp.) & $22493 \pm 107$ & $27162-26464$ & 26815 & Zilhão \& Trinkaus 2000 \\
\hline & Lagar Velho & GRA & us & OxA-10303 & $\mathrm{CH}$ & $22390 \pm 280$ & $27282-26067$ & 26679 & Pettitt et al., 2002 \\
\hline & Lagar Velho & GRA & 6 & OxA-8418 & $\mathrm{CH}$ & $22180 \pm 180$ & $26961-26012$ & 26412 & Zilhão \& Trinkaus 2000 \\
\hline & Lagar Velho & GRA & GC3 & OxA-9571 & $\mathrm{B}$ & $21130 \pm 130$ & $25760-25170$ & 25476 & Zilhão and Trinkaus 2000 \\
\hline & Lagar Velho & GRA & us & OxA-8426 & $\mathrm{CH}$ & $20570 \pm 130$ & $25195-24278$ & 24773 & Zilhão \& Trinkaus 2000 \\
\hline
\end{tabular}




\begin{tabular}{|c|c|c|c|c|c|c|c|c|}
\hline Lagar Velho & SOL & 9 & OxA-8419 & $\mathrm{CH}$ & $20200 \pm 180$ & $24861-23840$ & 24282 & Zilhão \& Trinkaus 2000 \\
\hline Laminak II & MGD & - & CAMS-9918 & $\mathrm{CH}$ & $12340 \pm 60$ & $14718-14088$ & 14348 & Berganza \& Arribas, 1994 \\
\hline Laminak II & MGD & II & Ua-2362 & $\mathrm{B}$ & $11700 \pm 140$ & $13810-13237$ & 13534 & Berganza \& Arribas, 1994 \\
\hline Lapa dos Coelhos & MGD & 4 & GrN-18377 & $\mathrm{CH}$ & $12240 \pm 60$ & $14459-13955$ & 14147 & Bicho and Haws, 2012 \\
\hline Lapa dos Coelhos & MGD & 3 & GrN-1876 & $\mathrm{CH}$ & $11660 \pm 60$ & $13595-13341$ & 13492 & Bicho and Haws, 2012 \\
\hline Lapa dos Picaeiros & MGD & $\mathrm{N}$ & Wk-16417 & $\mathrm{B}$ & $16389 \pm 111$ & $20067-19510$ & 19781 & Bicho and Haws, 2012 \\
\hline Lapa dos Picaeiros & MGD & $\mathrm{K}$ & WK-31354 & B & $15035 \pm 87$ & $18508-18005$ & 18268 & Bicho and Haws, 2012 \\
\hline Lapa dos Picaeiros & MGD & E middle & Wk-10434 & $\mathrm{CH}$ & $12500 \pm 160$ & $15227-14106$ & 14684 & Bicho and Haws, 2012 \\
\hline Lapa dos Picaeiros & MGD & G & OxA-5527 & $\mathrm{CH}$ & $12320 \pm 90$ & $14817-14009$ & 14345 & Bicho and Haws, 2012 \\
\hline Lapa dos Picaeiros & MGD & $\mathrm{F}$ & Wk-6677 & $\mathrm{CH}$ & $12210 \pm 100$ & $14590-13775$ & 14121 & Bicho and Haws, 2012 \\
\hline Lapa dos Picaeiros & MGD & $\mathrm{J}$ & Wk-6678 & $\mathrm{CH}$ & $11880 \pm 80$ & 13951-13877 & 13689 & Bicho and Haws, 2012 \\
\hline Lapa dos Picaeiros & MGD & $\mathrm{F}$ & Wk-4219 & $\mathrm{CH}$ & $11780 \pm 90$ & 13771-13442 & 13612 & Bicho and Haws, 2012 \\
\hline Lapa dos Picaeiros & MGD & E middle & Wk-5431 & $\mathrm{CH}$ & $11700 \pm 120$ & $13761-13297$ & 13532 & Bicho and Haws, 2012 \\
\hline Lapa dos Picaeiros & MGD & E lower & Wk-4218 & $\mathrm{CH}$ & $11550 \pm 120$ & 13596-13119 & 13381 & Bicho and Haws, 2012 \\
\hline Lapa dos Picaeiros & MGD & $\mathrm{J}$ & WK-10433 & $\mathrm{CH}$ & $10490 \pm 110$ & $12679-12053$ & 12399 & Bicho and Haws, 2012 \\
\hline Lapa dos Picaeiros & MGD & E upper & Wk-4217 & $\mathrm{CH}$ & $10070 \pm 80$ & 11979-11306 & 11623 & Bicho and Haws, 2012 \\
\hline Las Aguas & MGD & B4 & GrA-21524 & $\mathrm{CH}$ & $15030 \pm 60$ & $18452-18045$ & 18263 & Uzquiano, 2014 \\
\hline Las Aguas & MGD & B3 & GrA-21525 & $\mathrm{CH}$ & $14550 \pm 60$ & $17930-17541$ & 17732 & Uzquiano, 2014 \\
\hline Las Aguas & MGD & B1 & GrA-21526 & $\mathrm{B}$ & $14440 \pm 70$ & $17859-17385$ & 17602 & Uzquiano, 2014 \\
\hline Las Caldas & SOL & 15 (sala I) & Ua-15318 & $\mathrm{CH}$ & $20250 \pm 235$ & $25075-23798$ & 24363 & Corchón, 1999 \\
\hline Las Caldas & SOL & 16 & Ly-2428 & $\mathrm{B}$ & $19510 \pm 330$ & $24246-22686$ & 23487 & Evin et al., 1983 \\
\hline Las Caldas & SOL & 12b (pasillo) & Ly-2426 & B & $19480 \pm 260$ & $24079-22825$ & 23455 & Evin et al., 1983 \\
\hline Las Caldas & SOL & 9 (pasillo) & Ly-2424 & B & $19390 \pm 260$ & 23983-22711 & 23348 & Corchón, 1999 \\
\hline Las Caldas & SOL & 12t (pasillo) & Ly-2425 & $\mathrm{B}$ & $19030 \pm 320$ & $23730-22289$ & 22947 & Evin et al., 1983 \\
\hline Las Caldas & SOL & 18 & Ly-2429 & $\mathrm{B}$ & $19000 \pm 280$ & $23589-22347$ & 22907 & Evin et al., 1983 \\
\hline Las Caldas & SOL & 7 (pasillo) & Ly-2423 & $\mathrm{B}$ & $18310 \pm 260$ & $22717-21492$ & 22142 & Jordá et al., 1992 \\
\hline Las Caldas & SOL & 11 (sala I) & UA-15316 & $\mathrm{B}$ & $18305 \pm 295$ & 22813-21402 & 22130 & Corchón, 1999 \\
\hline Las Caldas & SOL & 3 (pasillo) & Ly-2421 & $\mathrm{B}$ & $18250 \pm 300$ & $22753-21305$ & 22072 & Jordá et al., 1992 \\
\hline Las Caldas & SOL & XIVc (sala II) & Ua-4302 & $\mathrm{B}$ & $17380 \pm 215$ & $21605-20444$ & 20996 & Corchón, 1999 \\
\hline Las Caldas & SOL & II-XIVc & Ua-4302 & $\mathrm{B}$ & $17380 \pm 215$ & $21605-20444$ & 20993 & Corchón, 1994 \\
\hline Las Caldas & SOL & 4 (pasillo) & Ly-2422 & B & $17050 \pm 290$ & 21366-19858 & 20576 & Crochón, 2012 \\
\hline Las Caldas & SOL & Pasillo 4 & Ly-2422 & $\mathrm{B}$ & $17050 \pm 290$ & 21366-19858 & 20576 & Corchón, 1999 \\
\hline
\end{tabular}




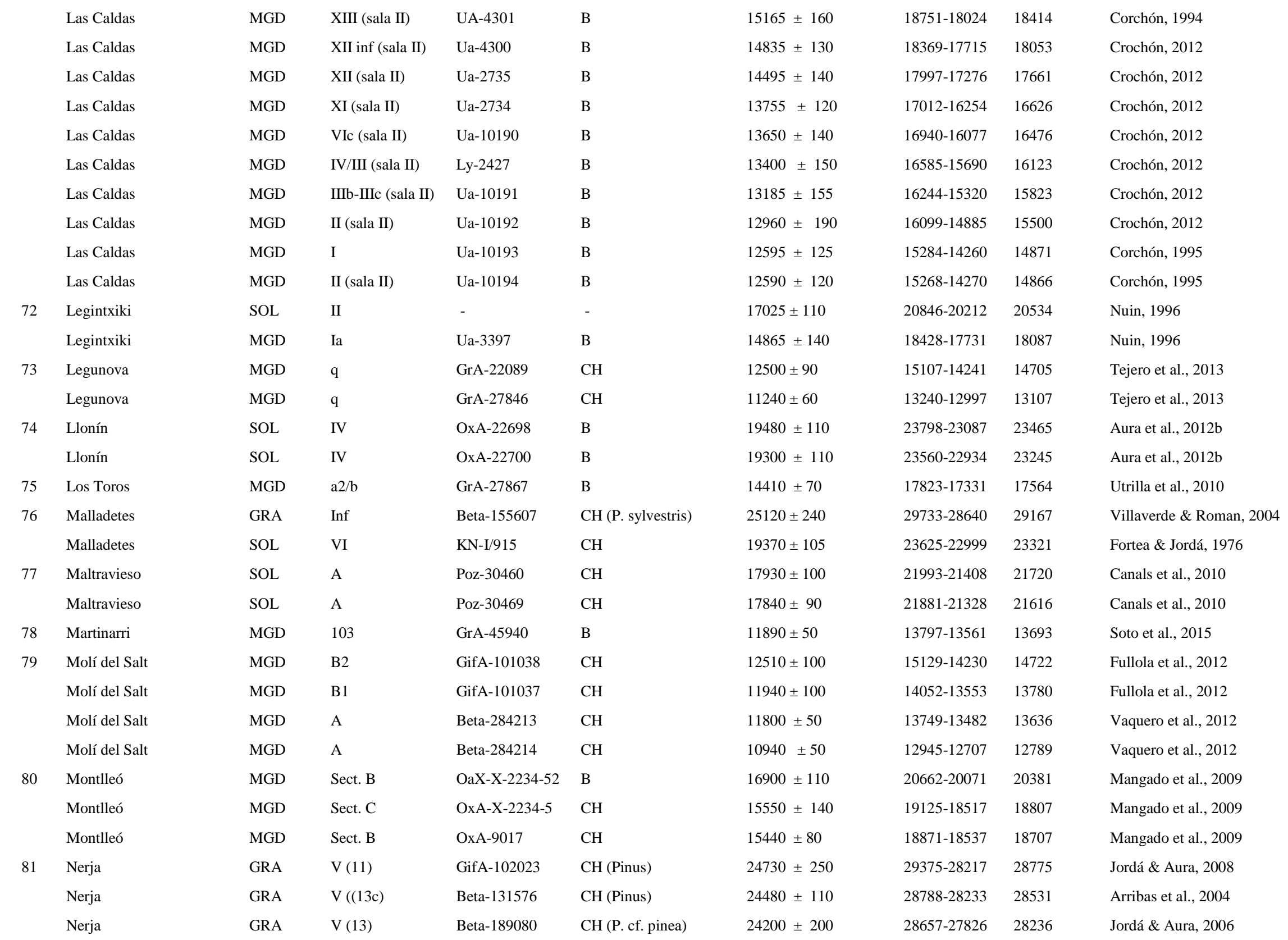




\begin{tabular}{|c|c|c|c|c|c|c|c|c|c|}
\hline & Nerja & SOL & V (9) & GifA-102021 & CH (Pinus) & $21140 \pm 190$ & $25863-25042$ & 25475 & Aura et al., 2006 \\
\hline & Nerja & SOL & $\mathrm{V}(8 \mathrm{c})$ & UBAR-98 & $\mathrm{CH}$ & $17940 \pm 200$ & $22279-21165$ & 21720 & Jordá et al., 1990 \\
\hline & Nerja & SOL & $\mathrm{V}(8 \mathrm{i})$ & UBAR-157 & $\mathrm{CH}$ & $15990 \pm 260$ & 19938-18752 & 19303 & Jordá et al., 1990 \\
\hline & Nerja & MGD & $\mathrm{VI}(\mathrm{N} .8)$ & GAK-8966 & $\mathrm{CH}$ & $13780 \pm 340$ & $17619-15727$ & 16673 & Pellicer \& Acosta, 1997 \\
\hline & Nerja & MGD & VI (N.9) & GAK-8976 & $\mathrm{CH}$ & $13330 \pm 270$ & $16836-15224$ & 16020 & Pellicer \& Acosta, 1997 \\
\hline & Nerja & MGD & $\mathrm{M}(16)$ & UGRA-98 & $\mathrm{CH}$ & $12270 \pm 220$ & $15130-13721$ & 14340 & Jordá et al., 1990 \\
\hline & Nerja & MGD & $\mathrm{V}(6)$ & UBAR-155 & $\mathrm{CH}$ & $12190 \pm 150$ & $14818-13725$ & 14127 & Jordá et al., 1990 \\
\hline & Nerja & MGD & $\mathrm{V}(7)$ & UBAR-156 & $\mathrm{CH}$ & $12130 \pm 130$ & $14576-13628$ & 14010 & Jordá et al., 1990 \\
\hline & Nerja & MGD & $\mathrm{V}(5)$ & Ubar-154 & $\mathrm{CH}$ & $11930 \pm 160$ & $14159-13439$ & 13780 & Jordá et al., 1990 \\
\hline & Nerja & MGD & M (16) & UGRA-147 & $\mathrm{CH}$ & $11930 \pm 150$ & $14124-13456$ & 13777 & Jordá et al., 1990 \\
\hline & Nerja & MGD & $M(16 e)$ & Ubar-97 & $\mathrm{CH}$ & $11850 \pm 190$ & $14138-13291$ & 13696 & Jordá et al., 1990 \\
\hline & Nerja & MGD & $\mathrm{T}-17$ & Beta-193273 & $\mathrm{CH}$ & $11810 \pm 40$ & $13754-13491$ & 13646 & Sanchidrián \& Marquez, 2005 \\
\hline 82 & Parco & MGD & $\mathrm{XI}$ & GofA- 95552 & $\mathrm{CH}$ & $14300 \pm 150$ & $17843-16991$ & 17409 & Fullola et al., 2012 \\
\hline & Parco & MGD & VII & GifA-95542 & $\mathrm{CH}$ & $14040 \pm 140$ & $17480-16591$ & 17055 & Fullola et al., 2012 \\
\hline & Parco & MGD & VI & AA-8644,T459 & $\mathrm{CH}$ & $13950 \pm 150$ & $17396-16430$ & 16915 & Bergadá, 1998 \\
\hline & Parco & MGD & $\mathrm{V}$ & GifA-95565 & $\mathrm{CH}$ & $13890 \pm 130$ & $17232-16370$ & 16825 & Bergadá, 1998 \\
\hline & Parco & MGD & VII & GifA-95547 & $\mathrm{CH}$ & $13720 \pm 140$ & $17020-16170$ & 16577 & Fullola et al., 2012 \\
\hline & Parco & MGD & II-XII & OxA-23650 & CH (Pinus) & $13475 \pm 50$ & $16430-16018$ & 16216 & Fullola et al., 2012 \\
\hline & Parco & MGD & II & OxA-10798 & $\mathrm{CH}$ & $13175 \pm 60$ & $16055-15617$ & 15833 & Mangado et al., 2006 \\
\hline & Parco & MGD & III & OxA-17730 & $\mathrm{CH}$ & $13095 \pm 55$ & $15949-15433$ & 15711 & Fullola et al., 2012 \\
\hline & Parco & MGD & III & GifA-95564 & $\mathrm{CH}$ & $13070 \pm 140$ & $16066-15235$ & 15652 & Bergadá, 1998 \\
\hline & Parco & MGD & IV & AA- 8643, T458 & B & $12900 \pm 130$ & $15850-15043$ & 15434 & Fullola et al., 2012 \\
\hline & Parco & MGD & II & OxA-10797 & $\mathrm{CH}$ & $12460 \pm 60$ & $15004-14235$ & 14612 & Fullola et al., 2012 \\
\hline & Parco & MGD & $\mathrm{Ib}$ & OxA-8656 & $\mathrm{CH}$ & $11430 \pm 60$ & $13412-13134$ & 13270 & Bergadá, 1998 \\
\hline & Parco & MGD & Ic & OxA-8657 & $\mathrm{CH}$ & $11270 \pm 90$ & $13316-12944$ & 13137 & Bergadá, 1998 \\
\hline 83 & Parpalló & SOL & T6 & OxA-22651 & B & $19020 \pm 100$ & $23228-22562$ & 22896 & Zilhão, 2010 \\
\hline & Parpalló & SOL & $\mathrm{T} 11$ & OxA-18510 & B (Capra pyrenaica) & $18510 \pm 100$ & $22615-22089$ & 22386 & Davidson, 1974 \\
\hline & Parpalló & SOL & $4.25-4.00$ & Birm-521 & B & $17900 \pm 340$ & 22431-20798 & 21647 & Davidson, 1974 \\
\hline 84 & Peña Capón & GRA & 4 & Beta-246878 & $\mathrm{T}$ & $21220 \pm 120$ & $25817-25263$ & 25566 & Alcaraz-Castaño et al., 2012 \\
\hline & Peña Capón & GRA & 2 & Beta-246880 & $\mathrm{T}$ & $19930 \pm 110$ & $24281-23670$ & 23982 & Alcaraz-Castaño et al., 2012 \\
\hline & Peña Capón & SOL & 4 & Beta-246878 & $\mathrm{T}$ & $21220 \pm 120$ & $25-817-25263$ & 25566 & Alcaraz-Castaño et al., 2012 \\
\hline & Peña Capón & SOL & 3 & Beta-246879 & $\mathrm{T}$ & $19980 \pm 110$ & $24335-23733$ & 24039 & Alcaraz-Castaño et al., 2012 \\
\hline
\end{tabular}


Rascaño

Rascaño

Rascaño

91 Ratla del Bubo

Ratla del Bubo

92 Salemas

Salemas

93 Santa Catalina

Santa Catalina

94 Santa Maira

95 Santimamiñe

\begin{tabular}{|c|c|c|c|}
\hline MGD & VI & Beta-228871 & $\mathrm{CH}$ \\
\hline MGD & VI & Beta-197378 & $\mathrm{CH}$ \\
\hline MGD & IV & Beta-290780 & $\mathrm{CH}$ \\
\hline MGD & III & Beta-232939 & $\mathrm{CH}$ \\
\hline MGD & III & Beta-232940 & $\mathrm{CH}$ \\
\hline MGD & II & Beta-197376 & OS \\
\hline MGD & II & Beta-155116 & $\mathrm{CH}$ \\
\hline MGD & I & Beta-287754 & $\mathrm{CH}$ \\
\hline MGD & I & Beta-290779 & $\mathrm{CH}$ \\
\hline MGD & 2 & $\mathrm{GrN}-21014$ & $\mathrm{CH}$ \\
\hline MGD & $2 \mathrm{c}$ & GrN-20962 & $\mathrm{CH}$ \\
\hline GRA & VI & GrA-28025 & B \\
\hline GRA & VI & Beta-341896 & B (Cervus elaphus) \\
\hline SOL & V (Vestíbulo) & GrA-24687 & B \\
\hline SOL & V (Vestíbulo) & Beta-162879 & B \\
\hline MGD & IV (vestíbulo) & GrA-24688 & B \\
\hline MGD & IV (vestíbulo) & GrA-20462 & B \\
\hline MGD & III (vestíbulo) & Beta-341897 & B (Raginfer tarandus) \\
\hline SOL & - & - & $\mathrm{CH}$ (Juniperus sp.) \\
\hline MGD & 5 & BM-1455 & - \\
\hline MGD & 4 & BM-1453 & B \\
\hline MGD & 3 & BM-1452 & - \\
\hline MGD & 2.3 & BM-1451 & - \\
\hline MGD & 2.1 & BM-1450 & - \\
\hline SOL & II & Ly-5219 & $\mathrm{CH}$ \\
\hline SOL & II & Ly-5809 & $\mathrm{CH}$ \\
\hline SOL & VS & ICEN-376 & B \\
\hline SOL & VS & ICEN-385 & B \\
\hline MGD & III & Ua-13877 & B \\
\hline MGD & II & Ua-13876 & - \\
\hline SOL & III-12 & Beta-317412 & $\mathrm{CH}$ (P. nigra/silvestris) \\
\hline MGD & Csn-Carm 41 & Beta-240904 & B (Red deer) \\
\hline
\end{tabular}

$\begin{array}{lll}17881-17380 & 17615 & \text { Cacho et al., 2012 } \\ 17486-17099 & 17291 & \text { Cacho et al., 2012 } \\ 15118-14370 & 14809 & \text { Cacho et al., 2012 } \\ 14934-14217 & 14561 & \text { Cacho et al., 2012 } \\ 14062-13772 & 13912 & \text { Cacho et al., 2012 } \\ 13723-13405 & 13524 & \text { Cacho et al., 2012 } \\ 13466-13055 & 13247 & \text { Cacho et al., 2012 } \\ 13279-13083 & 13178 & \text { Cacho et al., 2012 } \\ 12715-12435 & 12618 & \text { Cacho et al., 2012 } \\ 13013-12250 & 12674 & \text { Cacho et al., 2012 } \\ 14799-13565 & 14066 & \text { Straus et al., 2002 } \\ 29766-28974 & 29375 & \text { Peñalver, 2014 } \\ 27492-27003 & 27259 & \text { Peñalver, 2014 } \\ 23673-22886 & 23278 & \text { Peñalver, 2014 } \\ 21859-21390 & 21633 & \text { Peñalver, 2014 } \\ 19391-18824 & 19075 & \text { Peñalver, 2014 } \\ 18149-17612 & 17887 & \text { Peñalver, 2014 } \\ 15664-15434 & 15434 & \text { Peñalver, 2014 } \\ 23435-22842 & 23110 & \text { Zilhao et al., 2010 } \\ 20152-19512 & 19827 & \text { González-Echegaray \& Barandiarán, 1981 } \\ 19772-18841 & 19292 & \text { González-Echegaray \& Barandiarán, 1981 } \\ 18758-18032 & 18423 & \text { González-Echegaray \& Barandiarán, 1981 } \\ 15871-15001 & 15419 & \text { González-Echegaray \& Barandiarán, 1981 } \\ 14983-13780 & 14331 & \text { González-Echegaray \& Barandiarán, 1981 } \\ 21481-20497 & 20960 & \text { Soler et al., 1990 } \\ 21226-20680 & 20943 & \text { Soler et al., 1990 } \\ 25237-23616 & 24384 & \text { Zilhão, 1997 } \\ 23847-22479 & 23159 & \text { Zilhão, 1997 } \\ 15004-14145 & 14543 & \text { Berganza, 1992 } \\ 14974-14123 & 14508 & \text { Berganza, 1992 } \\ 24242-23664 & 23960 & \text { Aura \& Jordá, 2012 } \\ 18047-17641 & 17855 & \text { López-Quintana \& Guenaga Lizau, 2011 }\end{array}$




\begin{tabular}{|c|c|c|c|c|c|c|c|c|c|}
\hline & Santimamiñe & MGD & Csn-Carm 41 & Beta-240905 & B & $14650 \pm 80$ & $18039-17603$ & 17830 & López-Quintana \& Guenaga Lizau, 2011 \\
\hline & Santimamiñe & MGD & Slnc 20 & Beta-240902 & B (Red deer) & $12790 \pm 70$ & $15551-15036$ & 15243 & López-Quintana \& Guenaga, 2011 \\
\hline \multirow[t]{4}{*}{96} & Socuevas & MGD & $\mathrm{V}$ & Beta-312040 & B & $12040 \pm 50$ & $14042-13756$ & 13888 & Soto et al., 2015 \\
\hline & Socuevas & MGD & $\mathrm{V}$ & Beta-282216 & B & $11540 \pm 50$ & $13467-13281$ & 13378 & Soto et al., 2015 \\
\hline & Socuevas & MGD & IV & Beta-282215 & B & $11530 \pm 50$ & $13462-13276$ & 13371 & Soto et al., 2015 \\
\hline & Socuevas & MGD & $\mathrm{V}$ & Beta-312041 & B & $11530 \pm 50$ & $13462-13276$ & 13371 & Soto et al., 2015 \\
\hline 97 & Sopeña & GRA & III & Beta-198144 & B & $21020 \pm 100$ & $25628-25106$ & 25376 & Pinto, 2012 \\
\hline \multirow[t]{6}{*}{98} & Suao & MGD & 8 & GX-27593 & $\mathrm{CH}$ & $15110 \pm 90$ & $18597-18095$ & 18364 & Bicho and Haws, 2012 \\
\hline & Suao & MGD & 6 & GX-27589 & $\mathrm{CH}$ & $14380 \pm 90$ & $17817-17228$ & 17526 & Bicho and Haws, 2012 \\
\hline & Suao & MGD & 9 & GX-27594 & $\mathrm{CH}$ & $12590 \pm 80$ & $15222-14430$ & 14912 & Bicho and Haws, 2012 \\
\hline & Suao & MGD & 5 & GX-27591 & $\mathrm{CH}$ & $12590 \pm 100$ & $15239-14329$ & 14888 & Bicho and Haws, 2012 \\
\hline & Suao & MGD & 7 & GX-27590 & $\mathrm{CH}$ & $12410 \pm 80$ & $14954-14138$ & 14511 & Bicho and Haws, 2012 \\
\hline & Suao & MGD & 7 & GX-27592 & $\mathrm{CH}$ & $10900 \pm 70$ & $12957-12691$ & 12777 & Bicho and Haws, 2012 \\
\hline 99 & Terra do Manuel & GRA & $2 \mathrm{~s}$ & ETH-6038 & $\mathrm{CH}$ & $21770 \pm 210$ & $26482-25651$ & 26020 & Zilhão, 1997 \\
\hline \multirow[t]{3}{*}{100} & Tito Bustillo & MGD & $1 b-c$ & OxA-6260 & B & $14550 \pm 110$ & $17993-17448$ & 17725 & Uzquiano, 2014 \\
\hline & Tito Bustillo & MGD & $1 \mathrm{a} / \mathrm{b}$ & OxA-6258 & - & $13520 \pm 110$ & $16651-15949$ & 16286 & Moure, 1997 \\
\hline & Tito Bustillo & MGD & $1 b-c$ & OxA-6259 & - & $12850 \pm 90$ & $15677-15086$ & 15341 & Moure, 1997 \\
\hline 101 & Urtiaga & MGD & F inf. & GrN-5817 & B & $17050 \pm 140$ & 20938-20178 & 20565 & Altuna, 1972 \\
\hline 102 & Valdavara 1 & MGD & 4 & Beta-257849 & B & $15120 \pm 70$ & $18580-18149$ & 18380 & Alonso et al., 2012 \\
\hline 103 & Valdavara 2 & MGD & 4 & Beta-235726 & B & $14630 \pm 70$ & 18004-17604 & 17810 & Alonso et al., 2012 \\
\hline 104 & Valdavara 3 & MGD & 5 & Beta-235728 & B & $13770 \pm 70$ & $16934-16364$ & 16646 & Alonso et al., 2012 \\
\hline \multirow[t]{2}{*}{105} & Vale Almoinha & $\mathrm{SOL}$ & $5 \mathrm{SIII}$ & ICEN-71 & $\mathrm{CH}$ & $20380 \pm 150$ & 25024-24095 & 24509 & Zilhão, 1997 \\
\hline & Vale Almoinha & SOL & 5 AIII & Oxa-5676 & $\mathrm{CH}$ & $19940 \pm 180$ & $24415-23547$ & 23989 & Zilhão, 1997 \\
\hline \multirow[t]{9}{*}{106} & Vale Boi & GRA & 4 & Wk-24762 & $\mathrm{CH}$ & $24769 \pm 180$ & $29264-28407$ & 28808 & Bicho, 2008 \\
\hline & Vale Boi & GRA & 3 & Wk-13686 & B & $22470 \pm 235$ & 27293-26185 & 26768 & Bicho et al., 2010 \\
\hline & Vale Boi & GRA & $\mathrm{D} 4$ & Wk-26803 & $S$ & $21896 \pm 186$ & $26559-25799$ & 26130 & Bicho et al., 2010 \\
\hline & Vale Boi & GRA & 3 & Wk-16415 & S & $21830 \pm 195$ & $26512-25731$ & 26071 & Bicho, 2008 \\
\hline & Vale Boi & SOL & $\mathrm{C} 4$ & Wk-26800 & $\mathrm{CH}$ & $20620 \pm 160$ & $25290-24374$ & 24831 & Cascalheira, 2013 \\
\hline & Vale Boi & SOL & D2 & Wk-26802 & $\mathrm{CH}$ & $20570 \pm 158$ & $25241-24327$ & 24775 & Bicho et al., 2010 \\
\hline & Vale Boi & SOL & B1 & Wk-17840 & $\mathrm{CH}$ & $20340 \pm 160$ & $24996-24035$ & 24455 & Bicho, 2008 \\
\hline & Vale Boi & SOL & $\mathrm{C} 1$ & Wk-24763 & $\mathrm{CH}$ & $19533 \pm 92$ & $23839-23189$ & 23536 & Bicho, 2008 \\
\hline & Vale Boi & SOL & B6 & Wk-25765 & S & $18859 \pm 90$ & $22970-22478$ & 22716 & Bicho, 2008 \\
\hline
\end{tabular}




$\begin{array}{llllllllll} & \text { Vale Boi } & \text { SOL } & \text { Vertiente 2 } & \text { Wk-12130 } & \text { B } & 18410 \pm 165 & 22583-21857 & 22258 & \text { Bicho \& Stiner, 2006 } \\ & \text { Vale Boi } & \text { SOL } & \text { Vertiente 2 } & \text { Wk-12131 } & \text { CH } & 17634 \pm 110 & 21682-20968 & 21324 & \text { Bicho, 2008 } \\ & \text { Vale Boi } & \text { MGD } & \text { Z1 } & \text { Wk-31088 } & \text { Tooth } & 15660 \pm 86 & 19125-18726 & 18903 & \text { Pereira et al., 2016 } \\ 107 & \text { Vergara } & \text { MGD } & \text { D } & \text { GrN.A-8403 } & \text { T (Horse) } & 14000 \pm 100 & 17355-16623 & 16999 & \text { Cacho et al., 2012 } \\ 108 & \text { Zatoya } & \text { MGD } & \text { IIB } & \text { GrN-23998 } & \text { B } & 12205 \pm 90 & 14512-13775 & 14106 & \text { Barandiarán \& Cava, 2008 } \\ & \text { Zatoya } & \text { MGD } & \text { II } & \text { Ly-1400 } & \text { B } & 11840 \pm 240 & 14355-13124 & 13704 & \text { Barandiarán \& Cava, 1994 } \\ & \text { Zatoya } & \text { MGD } & \text { II } & \text { Ly-1399 } & - & 11480 \pm 270 & 13841-12743 & 13328 & \text { Barandiarán \& Cava, 1994 }\end{array}$




\section{References to Supplementary material}

Aguirre, M. 2012. Ocupaciones gravetienses de Antoliñako koba: aproximación preliminar a su estratigrafía, cronología e industrias. In: de las Heras, C., Lasheras, J.A., Arrizabalaga, A., de la rasilla, M. (Coords). Pensando el Gravetiense: nuevos datos para la región cantábrica en su contexto peninsular y pirenaico. Monografías del Museo de Altamira 23, Madrid, 216-228.

Alcaraz-Castaño, M., Alcolea, J. de Balbín, R., García-Valero, M.A., Yravedra, J., Baena, J. 2012. Entre el Gravetiense y el Solutrense: el nivel 3 de Peña Capón (valle del Sorbe, Guadalajara). In: de las Heras, C., Lasheras, J.A., Arrizabalaga, A., de la rasilla, M. (Coords). Pensando el Gravetiense: nuevos datos para la región cantábrica en su contexto peninsular y pirenaico. Monografías del Museo de Altamira 23, Madrid, 126-140.

Almeida, F., Brugal, J. P., Zilhão, J., Plisson, H. 2007. An upper Paleolithic Pompeii: Technology subsistence and Paleoethnography at Lapa do Anecrial. In: N. Bicho (Ed.): From the Mediterranean basin to the Portuguese Atlantic shore : papers in honor of Anthony Mark: actas do IV Congresso de Arqueologia Peninsular. Universidad do Algarve.

Alonso, S., Vaquero, M., Armeijenda, A. 2012. La Cova de Valdavara y valdavara 3 (Becerreá, Lugo). In: Sala-Ramos, R. (Ed). Los cazadores recolectores del Pleistoceno y del Holoceno en Iberia y el Estrecho de Gibraltar: estado actual del conocimiento del registro arqueológico. Universidad de Burgos, Burgos, 31-34.

Altuna, J. 1972. Fauna de mamíferos de los yacimientos prehistóricos de Guipúzcoa. Munibe 24, 1-464.

Altuna, J., Merino, J.M. 1984. El yacimiento prehistórico de la cueva de Ekain (Deba, Guipúzcoa), Eusko Ikaskuntza, San Sebastián.

Altuna, J.; Baldeón, A.; Mariezkurrena, K. (eds.) 1985. Cazadores magdalenienses en la cueva de Eralla (Cestona-País Vasco). Munibe (Antropologia-Arkeología), 37: 7-206.

Altuna, J., Mariezkurrena, K, Ríos, J. 2011. Ocupaciones humanas en Aitzbitarte III (País Vasco) 33.600-18.400 BP (Zona de entrada a la cueva). Gobierno Vasco, Votoria-Gasteiz.

Álvarez, E. 2001. Altamire revised: Nuevos datos, Interpretaciones y reflexiones sobre la industria ósea y la malacofauna. Espacio, Tiempo y Forma, Serie I, Prehistoria y Arqueología 14, 167-184.

Aubry, T., Brugal, J.P., Chauvière, F.X., Figueral, I., Moura, M.-H., Plisson, H. 2001. Modalités d'occupations au Paléolithique supérieur dans la grotte de Buraca Escura (Redinha, Pombal, Portugal). Revista Portugesa de Arqueologia 4, 19-46.

Aura, J.E., Jordá-Pardo, J.F., Fortea, J. 2006. La Cueva de Nerja (Málaga, España) y los inicios del Solutrense en Andalucía. Zephyrus 59, 69-88.

Aura, J.E., Jordá-Pardo, J.F. 2012a. Solutrenses del Sur de Iberia en transición. Espacio, Tiempo y Forma, Serie I Nueva Época. Prehistoria y Arqueología 5, 149-169.

Aura, J.E., Tiffagom, M., Jordá, J.F., Duarte, E., Fernández de la Vega, J., Santamaría, D., de la Rasilla-Vives, Ripoll, M. 2012b. The Solutrean-Magdalenian transition: A view from Iberia. Quaternary International 272-273, 75-87.

Barandiarán, I. 1988. Datation C14 de l'Art mobilier magdalénien cantabrique, Prehistoire Ariégeoise XLIIL, 63-84. 
Barandiarán, I. 1990. Revisión estratigráfica de Berroberria. Datos en 1990. Veleia 7, 7-33. Vitoria

Barandiarán, I., Cava, A. 1994. Zatoya, sitio magdaleniense de caza en medio pirenaico. In: Monografía del Museo y centro de Interpretación de Altamira 17, 71-85.

Bergadà, M.M. 1998. Estudio geoarqueológico de los asentamientos prehistóricos del Pleistoceno Superior y el Holoceno inicial en Catalunya. BAR International Series 742, Oxford.

Bernaldo de Quirós, F., Castaños, P., Maillo, J.M., Neira, A. 2012. El Gravetiense de la cueva de El Castillo. Nuevos datos. In: de las Heras, C., Lasheras, J.A., Arrizabalaga, A., de la rasilla, M. (Coords). Pensando el Gravetiense: nuevos datos para la región cantábrica en su contexto peninsular y pirenaico. Monografías del Museo de Altamira 23, Madrid, 264-275.

Bicho, N., Manne, T., Cascalheira, J., Mendonça, C., Évora, M., Gibaja, J.F., Pereira, T. 2010b. O Paleolitico superior do sudoeste da Península Ibérica: o caso do Algarve. In: X. Mangado (Coord.): El Paleolítico superior peninsular. Novedades del Siglo XXI. Universidad de Barcelona, Barcelona, 219-238.

Bicho, N. Haws, J. 2012. The Magdalenian in central and southern Portugal: Human ecology at the end of the Pleistocene. Quaternary international 272, 6-16.

Bicho, N. Haws, J., Marreiros, J. 2012. Desde el Mondego al Guadiana: la ocupación gravetiense de la fachada atñantica portuguesa. ). In: de las Heras, C., Lasheras, J.A., Arrizabalaga, A., de la rasilla, M. (coords), Pensando el Gravetiense: nuevos datos para la región cantábrica en su contexto peninsular y pirenaico. Monografías del Museo de Altamira 23, Madrid, 55-72.

Cacho, C., Martos, J.A., Jordá, J.F., Yravedra, J., Sesé, C., Zapata, L., Avezuelam B., Valdivia, J., Ruiz-Alonso, m., Marque, L., Martín-Lerma, I., Tejero, J.M. 2012. Human landscape of the Late Glacial period in the interior of the Iberian Peninsula: La Peña de Estebanvela (Segovia Spain). Quaternary International 272-273, 42-54.

Casanova, J., Martínez-Moreno, J., Mora, R. 2007. Traçant l'ocupació dels Pirineus: Balma Guilanyà i els caçadors-recol.lectors del Tardiglacial i l'Holocé antic al Prepirineu Oriental'. Tribuna d'Arqueologia 2006, 59-83

Corchón, M.S. 1995. Reflexiones acerca de la cronología del Magdaleniense cantábrico. Las dataciones 14C de la Cueva de Las Caldas (Asturias, España). Zephyrus 48, 3-19.

Corchón, M.S. 1999. Solutrense y Magdaleniense del oeste de la cornisa cantábrica: dataciones 14C (calibradas) y marco cronológico. Zephyrus 52, 3-32.

Corchón, M.S., Ortega, P., Vicente, F.J. 2015. El origen del Magdaleniense: una cuestión controvertida. La cueva de Las Caldas y los yacimientos del Nalón (Asturias, Norte de España). Munibe 66, 53-75.

Delibrias, G., Romain, O., Le Hasif, G. 1987. Datation par la méthode du carbone 14 du remplissage de la grotte de l'Arbreda. Cypsela 6, 133-135.

Domenech, E., Bergadà, M.M. y Roca de Togores, C. 2012. Nuevas aportaciones al Paleolítico superior medio de la Cova Beneito (Muro, Alacant). Recerques del Museu d'Alcoi 21, 7-18.

Finlayson, C., Giles-Pacheco, F., Rodríguez-Vidal, J., Fa, D.A., Guiterrez-López, J.M., Santiago-Pérez, A., Finlayson, G., Allue, E., Baena-Preysler, J., Cáceres, I., Carrión, J.S., Fernaández-Jalvo, Y., Gleed-Owen, C.P., Jimenez-Espejo, F.J., López, P., López-Sáez, J.A., Riquelme-Cantal, J.A., Sánchez-Marco, A., Giles-Guzman, F., Brown, K., Fuentez, N., Valarino, 
C.A., Villalpando, A., Stringer, C.B., Martinez-Ruiz, F., Sakamoto, T. 2006. Late survival of Neanderthals at the southernmost extreme of Europe. Nature 443, 850-853.

Fullola, J. M., Bartrolí, R., Cebrià, A., Bergadà, M., Farell, D., Nadal, J. (1994).El Paleolítico superior de Catalunya: El Gravetiense de la Balma de la Griera (Calafell. Baix Penedès, Tarragona). In: Actas del 1er Congreso de Arqueología Peninsular. Vol. III. Trabalhos de Antropologia e Etnologia, 34 (1-2), Oporto, 35-51.

Fullola, J.M., Mangado, X., Tejero, J.M., Petit, M.A., Bergadà, M.M., Nadal, J., GarcíaArguelles, P., Bartrolí, R., Mercadal, O. 2012. The Magdalenian in Catalonia. Quaternary International 272-273, 55-74.

Garcia-Ibaibarriaga, N., Rofes, J., Bailon, S., Garate, D., Rios-Garaizar, J., Martínez-García, B., Murelaga, X. 2015. A palaeoenvironmental estimate in Askondo (Bizkaia, Spain) using small vertebrates. Quaternary International 364, 244-254.

González-Echegaray, J., Freeman, L. 1978. Vida y muerte en Cueva Morín. Institución cultural de Cantabria. Diputación Provincial. Santander.

Gonzalez-Echegaray, J.; Barandiaran, I. 1981. El Paleolítico Superior de la cueva del Rascaño (Santander). Centro de investigación y museo de Altamira, Monografías 3, 211-220. Santander.

Gutierrez-Zugasti, I., Cuenca, D., González-Morales, M.R., García-Moreno, A. 2012. El aprovechamiento de moluscos y otros recursos litorales durante el Gravetiense en la región cantábrica: análisis arqueomalacológico de la cueva de la Fuente del Salín (Muñorrodero, Cantabria). In: de las Heras, C., Lasheras, J.A., Arrizabalaga, A., de la Rasilla, M. (coords), Pensando el Gravetiense: nuevos datos para la región cantábrica en su contexto peninsular y pirenaico. Monografías del Museo de Altamira 23, Madrid, 416-428.

de las Heras, C., Montes, Lasheras, J.A. 2012. Altamira. Nivel gravetiense y cronología de se arte rupestre. In: de las Heras, C., Lasheras, J.A., Arrizabalaga, A., de la Rasilla, M. (coords), Pensando el Gravetiense: nuevos datos para la región cantábrica en su contexto peninsular y pirenaico. Monografías del Museo de Altamira 23, Madrid, 476-491.

Jordá, J.F.; Aura Tortosa, E., Jordá Cerda, F. 1990. El límite Pleistoceno-Holoceno en el yacimiento de la Cueva de Nerja (Málaga). Geogaceta 8, 102-104.

Jordá, J.F., Aura, J.E. 2006. Radiocarbono, cronoestratigrafía y episodios ocupacionales en el Pleistoceno superior y Holoceno de la Cueva de Nerja (Málaga, Andalucía, España). In: MaílloFernández, J.M., Baquedano, E. (Eds.), Miscelánea en Homenaje a Victoria Cabrera. Zona Arqueológica, vol. 7, Madrid, 578-597.

Lucena, A., Martínez, S., Angelucci, D.E., Badal, E., Villaverde, V., Zapata, J., Zilhão, J. 2012. La ocupación Solutrense del abrigo de La Boja (Mula, Murcia, España). Espacio, Tiempo y Forma, Serie I Nueva Época. Prehistoria y Arqueología 5, 453-460.

Mangado, X., Mercadal, O., Fullola, J.M., Grimao, J. 2009. In: Fullola, J.M., Valdeyron, N. (Eds.), Els Pirineus i les àrees circundants durant el Tardiglacial. Mutacions i Filiacions. XIV Colloqui Internacional d'Arqueologia de Puigcerdà. Homenatge al Prof. Georges Laplace. Institu d'Estudis Ceretans, Puigcerdà, 549-564.

Maroto, J., Vaquero, M., Arriazabalaga, A., Baena, J., Baquedano, E., Jordá, J.F., Juliá, R., Montes, R., Van Der Plicht, J., Rasines, P., Wood, R. 2012. Current issues in late Middle Palaeolithic chronology: new assessments from Northern Iberia. Quaternary International 247, 15-25. 
Montes, L. 2005. El magdaleniense en el Prepirineo aragonés: últimos hallazgos. Actas do IV Congresso de Arqueologia Peninsular. O Paleolítico. Promontoria Monografica 02. Universidade do Algarve. Faro, pp. 183-192.

Mora, R., Benito-Calvo, A., Martínez, J., González Marcén, P., de la Torre, I. 2011. Chronostratigraphy of the Upper Pleistocene and Holocene archaeological sequence in Cova Gran (southeastern Pre-Pyrenees, Iberian Peninsula). Journal of Quaternary Science 26 (6), 635-644.

Moure, A. 1997. Dataciones AMS de la cueva de Tito Bustillo (Asturias). Trabajos de Prehistoria 54 (2), 135-142.

Nadal, J., Fullola, J.M., Esteve, X. 2006. Caballos y ciervos: una aproximación a la evolución climática y econó- mica del Paleolítico superior en el Mediterráneo Penínsular, Munibe 57, 313-324.

Peñalver, X., San José, S., Mujika-Alustiza, J.A. 2017. El yacimiento arqueológico de Praileaitz I (Deba, Gipuzkoa, Euskal Herria). Metodología de la excavación, estratigrafía, estructuras y dataciones arqueológicas. In: Peñalver, X., San José, S., Mujika-Alustiza, J.A. (Eds). La cueva de Praileaitz I (Deba, Gipuzkoa, Euskal Herria). Intervención arqueológica 2000-2009. Munibe Monographs. Anthropology and Archaeology Series 1. Sociedad de Ciencias Aranzadi, San Sebastián, 33-120.

Petit, M.A. 1998. Posar a l'hora el rellotge de la prehistòria: calibració de les datacions radiocarbòniques de la prehistòria moianesa. Modilianum 19, 3-20.

Pinto, A., Clark, G., Karnakas, P., Blackwell, B., Skinner, A. R., Andrews, P., Reed, K., Miller, A., Macías-Rosado, R. Y Vakiparta, J. 2012. The Sopeña Rockshelter, a new site in Asturias (Spain) bearing evidence on the Middle and Early Upper Palaeolithic in Northern Iberia. Munibe (Antropología-Arkeología) 63: 45-79.

Rasines, P. 2009. Geografía, estratigrafía y cronología de la cueva de Cobrante. In: Rasines, P. (Ed.) Arqueología en la cueva de Cobrante (Cantabria, España). Sautuola, Revista del Instituto de Prehistoria y Arqueologia Sautuola 15, 35-243.

Rasines, P, Muñoz, E. 2012. Los niveles gravetienses del abrigo de El Cuco (Castro urdiales, Cantabria). In: de las Heras, C., Lasheras, J.A., Arrizabalaga, A., de la rasilla, M. (coords), Pensando el Gravetiense: nuevos datos para la región cantábrica en su contexto peninsular y pirenaico. Monografías del Museo de Altamira 23, Madrid, 241-263

Rios, J., Iriarte-Avilés, E., Garate, D., Gómez-Olivencia, A., San Pedro Calleja, Z. 2008. Nuevos datos sobre la transición entre el Solutrense Superior y el Magdaleniense inferior en la Región cantábrica: la cueva de Arlanpe (Lemoa, Bizkaia), Sautuola 14, 95-104.

Ripoll, S. 1988. El Solutrense de la Cueva de Ambrosio (Almería, Spain) y su posición cronoestratigráfica en el Mediterráneo Occidental. BAR International Series, 462. Oxford.

Ripoll, S., Muñoz, F. J. y Fernández, J. L. 2006. Nuevos datos para el arte rupestre paleolítico de la cueva de Ambrosio (Vélez Blanco, Almería). In: J. Martínez y M. Hernández (Eds.), Congreso de Arte Rupestre Esquemático en la Península Ibérica. Almería, 573-588.

Rofes, J. Murelaga, X., Martínez-García, B., Bailon, S., López-Quintana, J.C. Guenaga-Lizasu, A., Ortega, L.A., Zuluaga, M.C., Alonso-Olazabal, A., Castaños, J., Castaños P. 2014. The long paleoenvironmental sequence of Santimamiñe (Bizkaia, Spain): 20,000 years of small mammal record from the latest Late Pleistocene to the middle Holocene. Quaternary International 364, 339340. 
Santamaría, D., Duarte, E., González-Pumariega, Martínez, L., Fernández, J., Santos, G., Highman, T., Wood, R., de la Rasilla, M. 2012. El abrigo de La Viña (Asturias). In: Sala-Ramos, R. (Ed). Los cazadores recolectores del Pleistoceno y del Holoceno en Iberia y el Estrecho de Gibraltar: estado actual del conocimiento del registro arqueológico. Universidad de Burgos, Burgos, 95-99.

Sommer, R., Zachos, F.E., Street, M., Jöris, O., Skog, A., Benecke, N. 2008. Late Quaternary distribution dynamics and phylogeography of the red deer (Cervus elaphus) in Europe. Quaternary Science Reviews 27, 714-733.

Soto, A., Alday, A., Montes, L., Utrilla, P., Perales, U., Domingo, R., 2015. Epipaleolithic assemblages in the Western Ebro Basin (Spain): The difficult identification of cultural entities. Quaternary International 364, 144-152.

Soto-Barreiro, M.J. 2003. Cronología radiométrica, ecología y clima del Paleolítico cantábrico. In: Monografías 19 (Museo Nacional y Centro de Investigación de Altamira). Ministerio de Educación Cultura y Deporte, Madrid.

Straus, L.G., González-Morales, M.R., Fano, M.A., García-Gelabert, M.P. 2002. Last glacial human settlement in Eastern Cantabria (northern Spain). Journal of Archaeoligcal Science 29, 1403 1414.

Straus, L.G., González-Morales, M.R. 2012. El Mirón Cave, Cantabrian Spain. The site and its Holocene Archaeological record. University of New Mexico Press, Alburquerque.

Trinkaus, E., Bailey, S.S., Davis, S.J.M., Zilhão, J. 2011. The Magdalenian Human Remains from the Galeria da Cisterna (Almonda karstic system, Torres Novas, Portugal) and their Archeological Context. O Arqueólogo Portugués (Serie V) 1, 395-413.

Utrilla, P., Blasco, F. 2000. Dos asentamientos magdalenienses en Deza, Soria. Boletín del Seminario de Estudios de Arte y Arqueología 66, 9-64.

Utrilla, P. Domingo, R. 2002. Informe de la campaña del 2000 en el abrigo de Ángel o arenal de Fonseca. Salduie 2, 337-353.

Utrilla, P., Montes, L., Mazo, C., Alday, A., Rodanés, JM., Blasco, MF., Domingo R., Bea M. 2010. El Paleolítico Superior en la Cuenca del Ebro a principios del s. XXI. Revisión y novedades. In: Mangado X. (Ed.) El Paleolítico superior Peninsular. Novedades del siglo XXI. Homenaje a Javier Fortea. Universidad de Barcelona, 23-62.

Utrilla, P., Mazo, C., Domingo, R. 2015. Fifty thousand years of prehistory at the cave of Abauntz (Arraiz, Navarre). A nexus point between the Ebro valley, Aquitaine and the Cantabrian corridor. Quaternary International 364, 294-305.

Utrilla, P., Domingo, R., Montes, L., Mazo, C., Rodanés, J.M., Blasco, F., Alday, A. 2012. The Ebro Basin in NE Spain: A crossroads during the Magdalenian. Quaternary International 272-273, 88-104.

Uzquiano, P. 2014. Wood resource exploitation by Cantabrian Late Upper Palaeolithic groups (N Spain) regarding MIS 2 vegetation dynamics. Quaternary International 337, 51-63.

Vega, L.G., Martín, P. 2006. Análisis preliminar de las cadenas operativas en el material lítico procedente del nivel IV del Abrigo del Palomar (Yeste, Albacete). Miscelánea en homenaje a Victoria Cabrera (E. Baquedano y J.M. Maíllo, eds.), Zona Arqueológica, Vol. 7(1): 396-405. 
Villaverde, V., Y Román, D. 2004. Avance al estudio de los niveles gravetienses de la Cova de les Cendres. Resultados de la excavación del sondeo (cuadros A/B/C-17) y su valoración en el contexto del Gravetiense mediterráneo ibérico. Archivo de Prehistoria Levantina XXV, 19-59.

Villaverde, V., Román, D. 2012. El Gravetiense de la vertiente mediterránea ibérica: estado de la cuestión y perspectivas. In: de las Heras, C., Lasheras, J.A., Arrizabalaga, A., de la rasilla, M. (Coords). Pensando el Gravetiense: nuevos datos para la región cantábrica en su contexto peninsular y pirenaico. Monografías del Museo de Altamira 23, Madrid, 34-54.

Villaverde, V., Román, D., Peréz-Ripoll, M., Bergadà, M.M., Real, C. 2012. The end of the Upper Palaeolithic in the Mediterranean Basin of the Iberian. Peninsula. Quaternary International 272-273, 17-32.

Yravedra, J., Gómez, A., Muñoz, E. 2010. Estrategias de subsistencia en el yacimiento paleolítico del Ruso (Igollo de Camargo, Cantabria, (España). Espacio, Tiempo y Forma, Serie I, Prehistoria y Arqueología 3, 39-58

Zilhão, J. 1997. O Paleolitico Superior da Estremadura Portuguesa. Colibri, Lisboa.

Zilhão, J. 2000. Nature and culture in Portugal from 30,000 to 20,000 BP. In: Roebroeks, W., Mussi, M., Svoboda, J., Fennema, K. (Eds.), Hunters of the Golden Age. The Mid Upper Palaeolithic of Eurasia 30,000 to 20,000 BP. University of Leiden, Leiden, 337-354. 


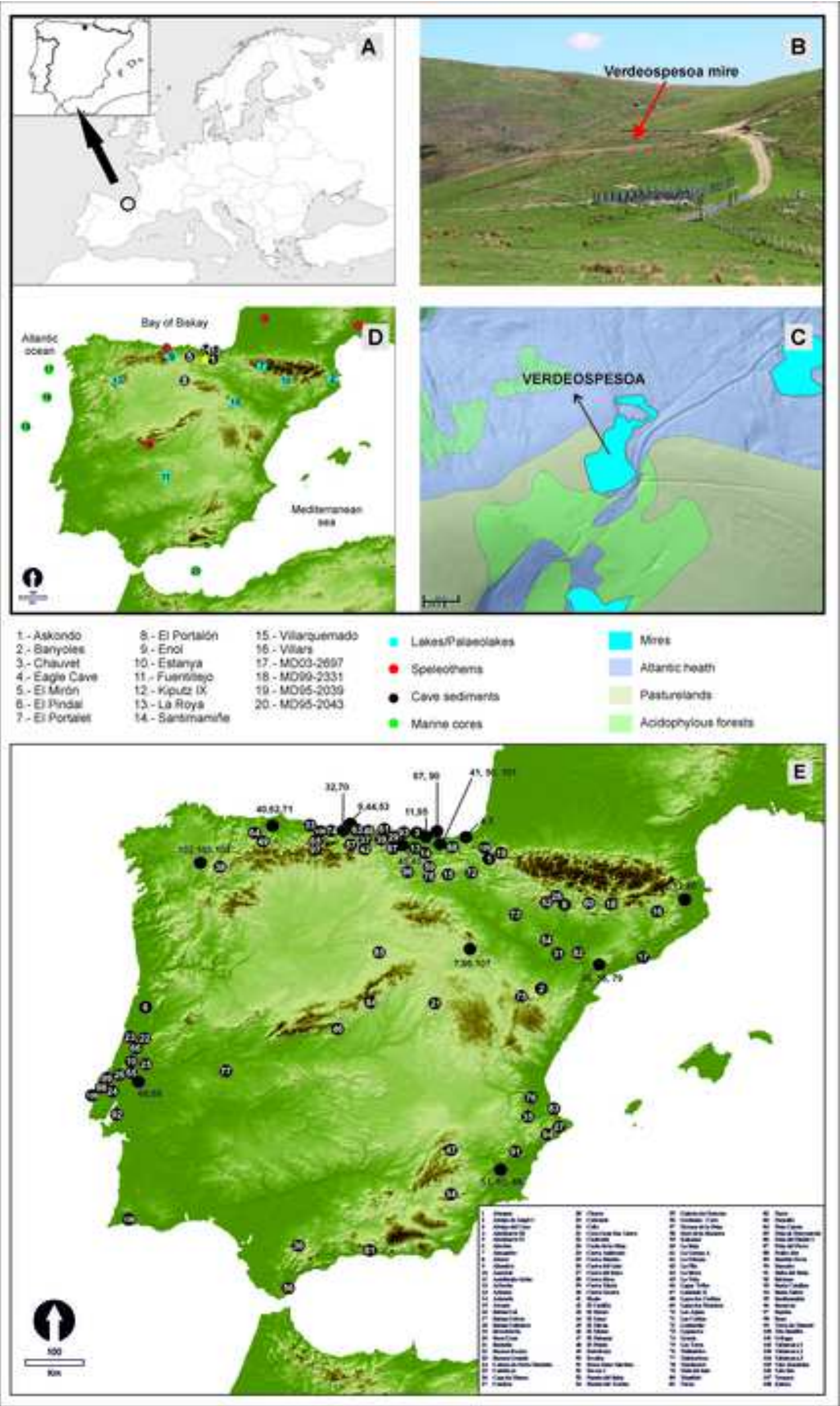




\begin{tabular}{|c|c|c|c|c|c|c|c|}
\hline & $\mathrm{x}$ & seas & Lerite & Arshliter & Anitusin af & Prem & Materenares \\
\hline \multirow[t]{16}{*}{ Temeitrol } & 1 & Aatingle & Goeidain Prou & Cescentimnis & $2 a$ & Semllenifyetes & 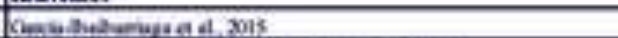 \\
\hline & 2. & Tivmests & Stmen mere & 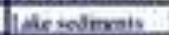 & 153 & 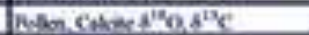 & 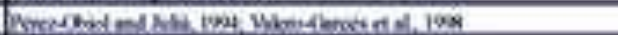 \\
\hline & 3 & Chenest & Sirtherer & Srabochtsm & $2 n$ & 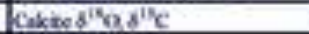 & Centratal, 2006 \\
\hline & 4 & Dovecrese & Coninallavin & Severedtere & 80 & conks s'lo & 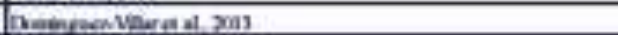 \\
\hline & 5 & butie: & Kestetression & Cosessinvets: & 20 & 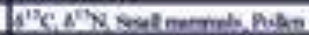 & 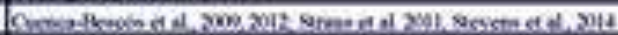 \\
\hline & 5 & Arshat & Conitrins Mrin & Srabothen & 24 & Caktes $s^{10} 0.8^{1} \mathrm{C}$ & Morosostal, Yitro \\
\hline & 7 & Hinestald & Bancanasu & Haionolininats & rime & melon & 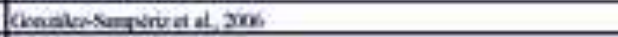 \\
\hline & $\$$ & IIIRnalle & NentimPleres & Goretalmuas & $\sin$ & Snilunitures & 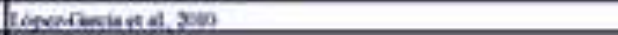 \\
\hline & 9 & Tined: & Geilan Rrith & 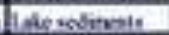 & $\log 6$ & Kokamiscomint & 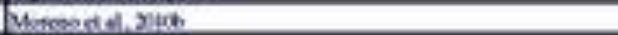 \\
\hline & $n$ & Brim: & Domoin was & inlegrodinnats & $\infty 0$ & Tibolys & Mordibinatat, 200 \\
\hline & III & Feailen & Soethen Mlests & Gevestimais & 100 & 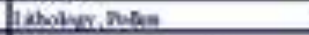 & Whase 4 43000 \\
\hline & 19 & Sictery & Kanterom Poves & Cose atimentis & 100 & 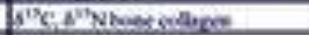 & 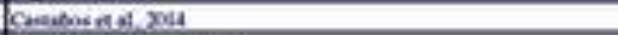 \\
\hline & 13 & lations & var porin & laterendingats & was & 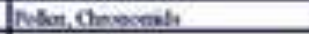 & 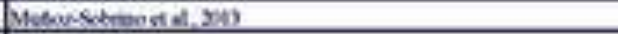 \\
\hline & 14 & Sonininase & Contitrie Roria & Covoublinants & 180 & Senil vendabutises & Eoflansal_2014 \\
\hline & 15 & 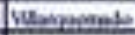 & Geinditern & filesodmats. & $\infty$ & Golen. Intwong & 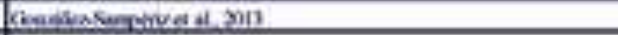 \\
\hline & is & SWlic & Donkins & Srabulatesty & 325 & 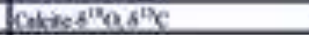 & Gonstal, $20 \%$ \\
\hline \multirow[t]{4}{*}{ Marise } & 17 & semotisat & Doriahneria & Marins rofirinets & 2166 & Gubm & 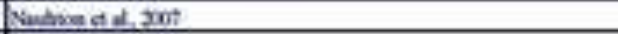 \\
\hline & 13 & Mrom-2031 & Donias marga & Mame coliniats & 2010 & minsm & 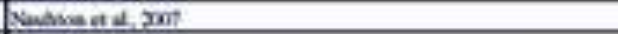 \\
\hline & w & monsum & 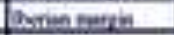 & Mamsieligets & - $x \mathrm{al}$ & foulas & Exwerathai \\
\hline & 2. & wons-yat & Skona Xag. & Mang solinnts & Hives & halk & 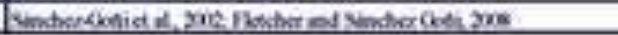 \\
\hline
\end{tabular}
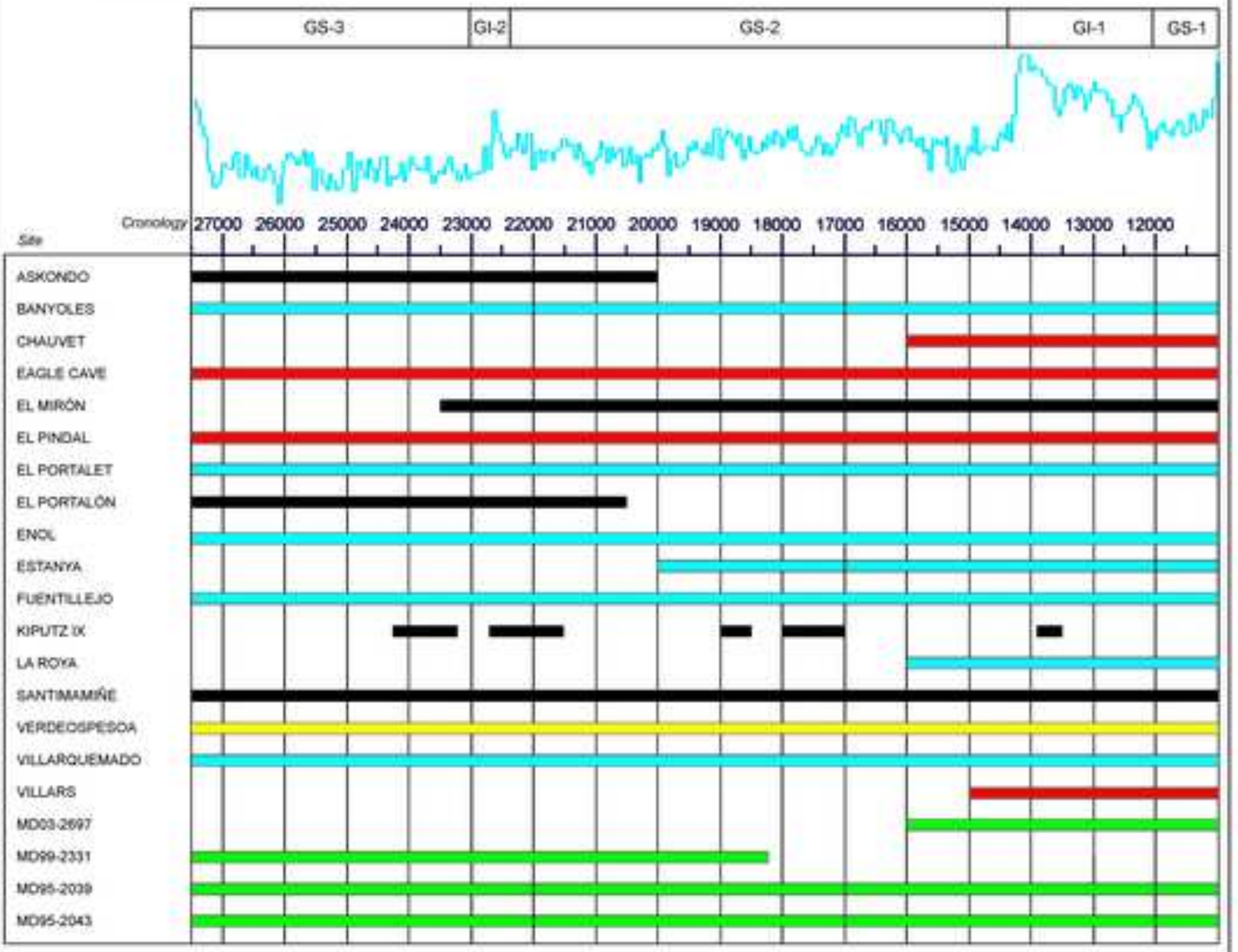


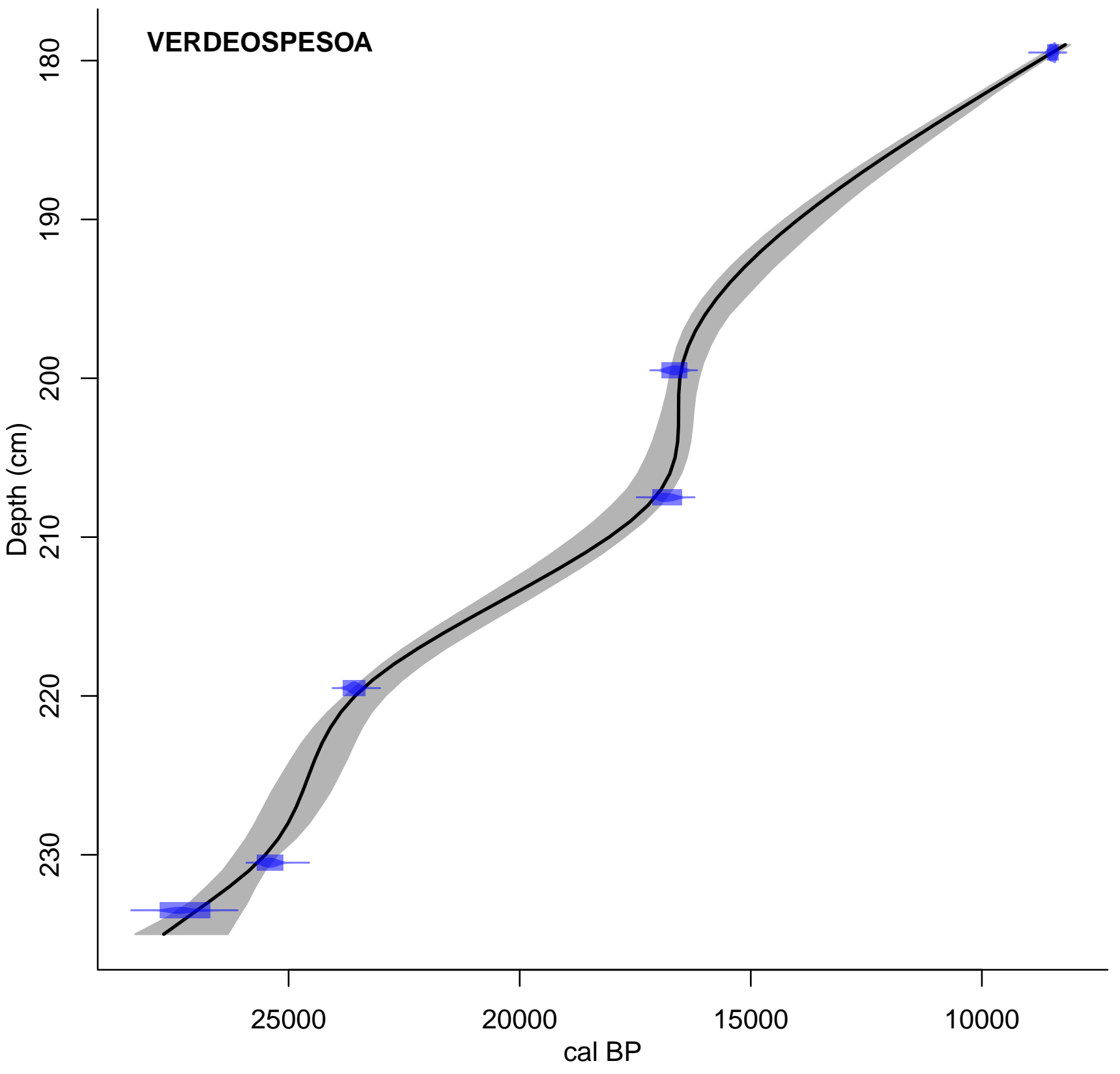




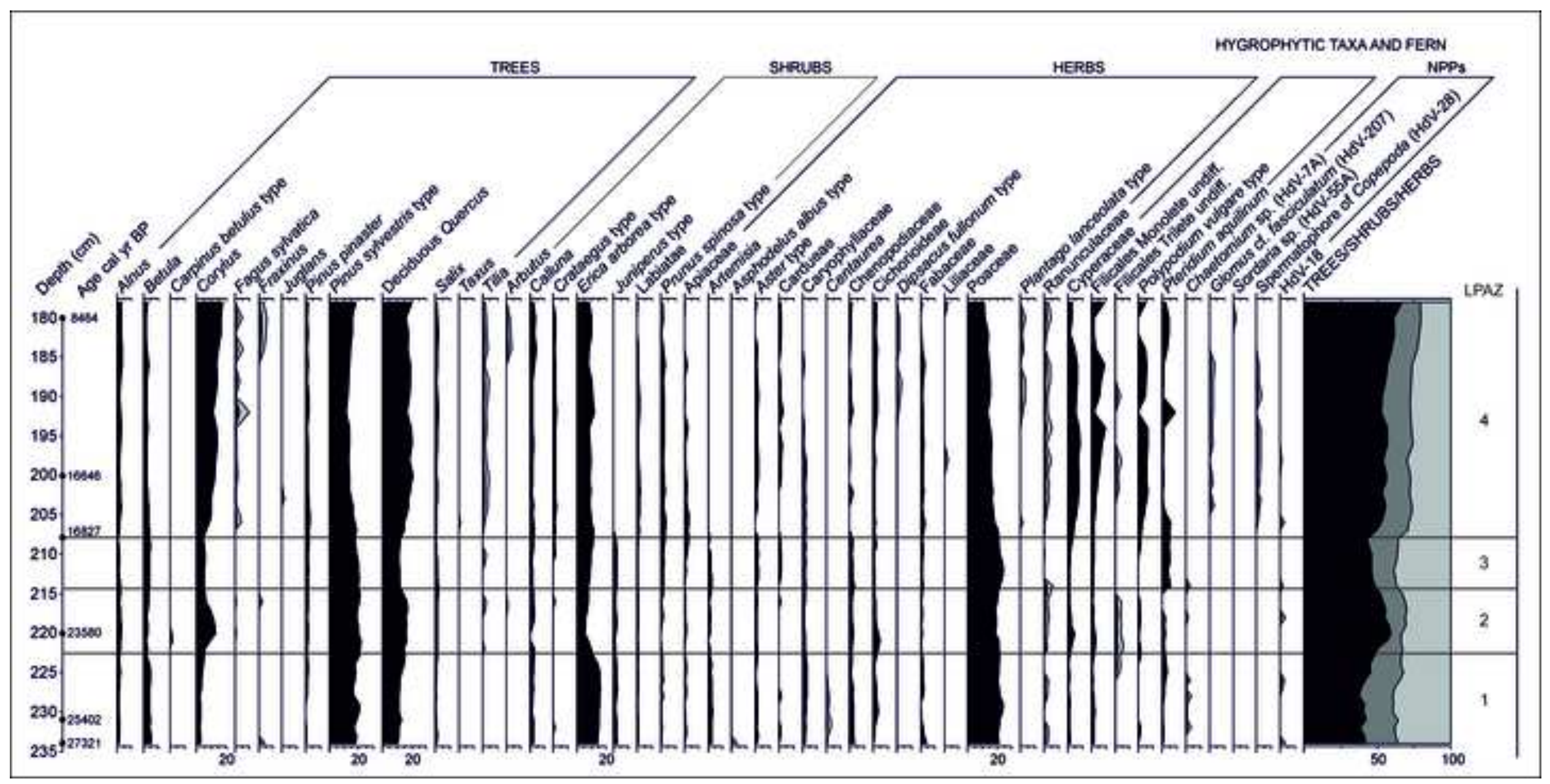



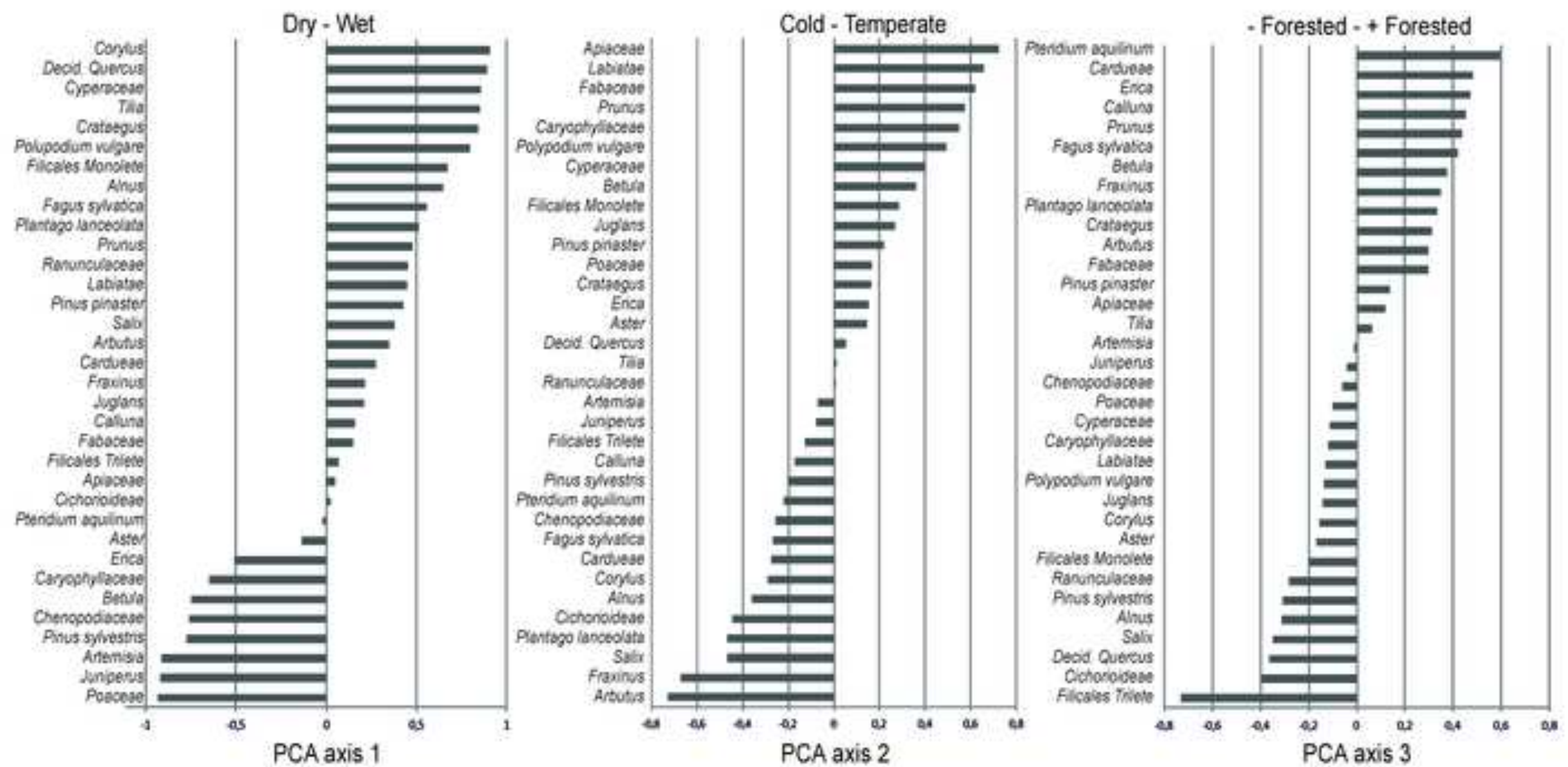


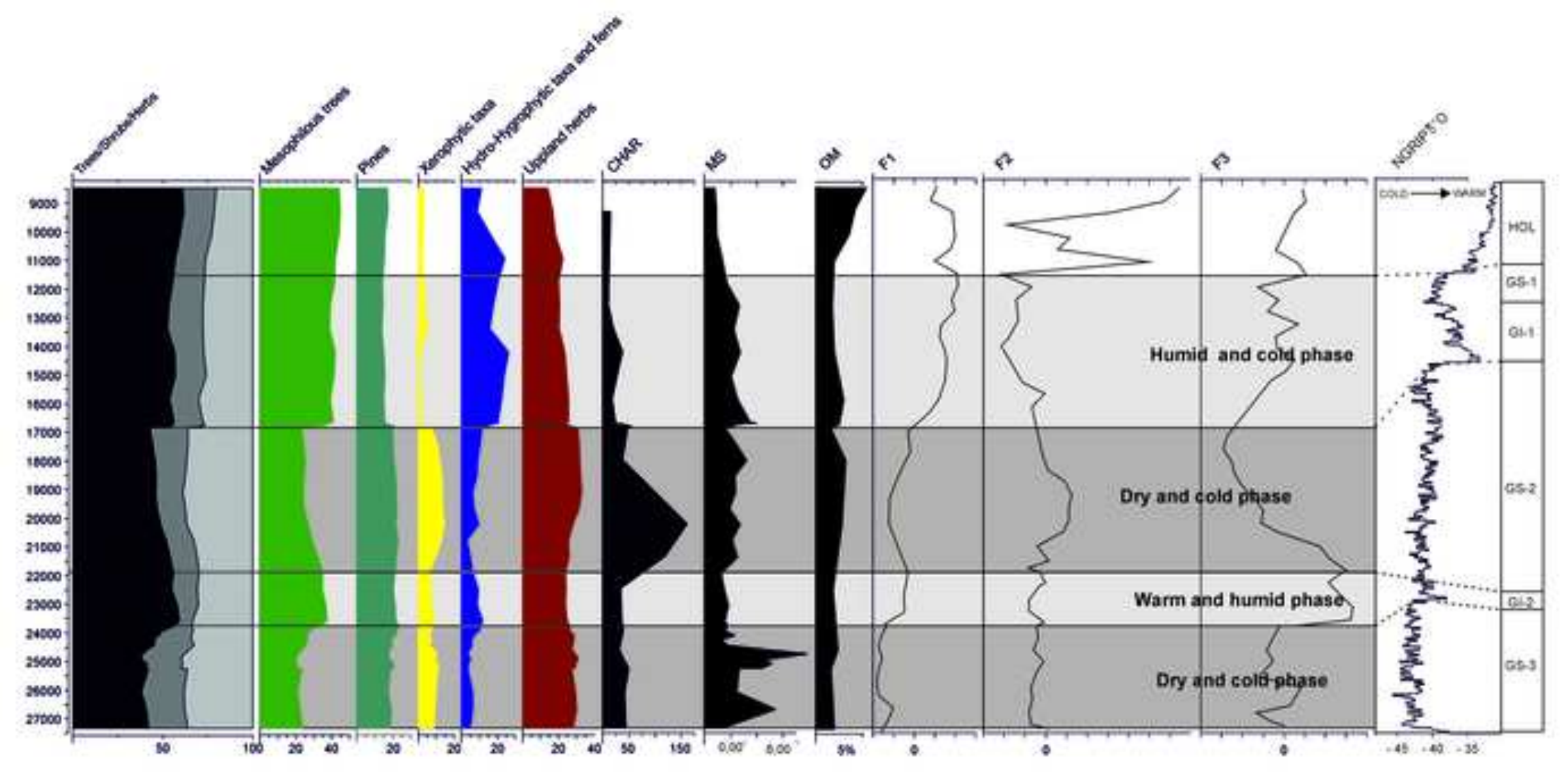



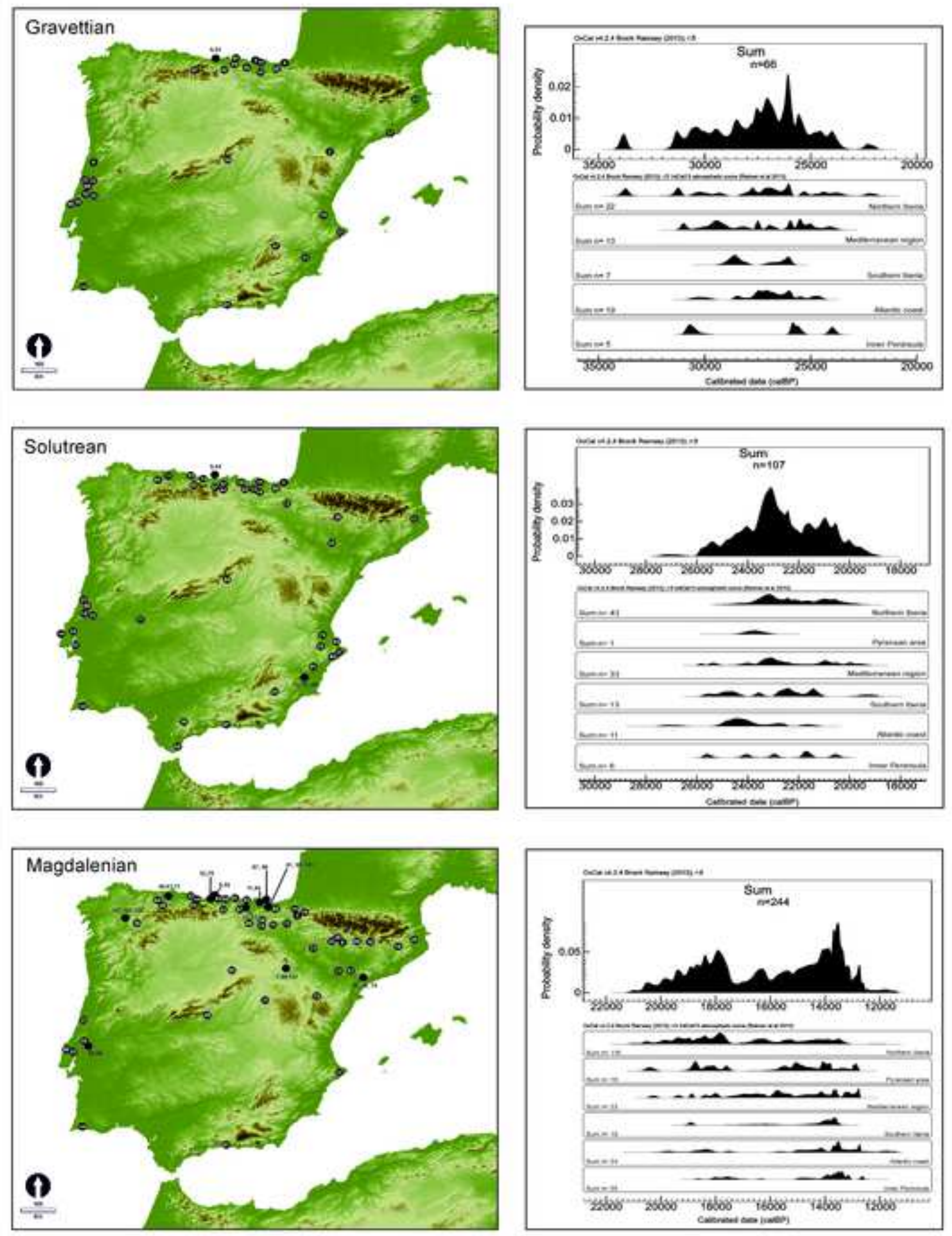


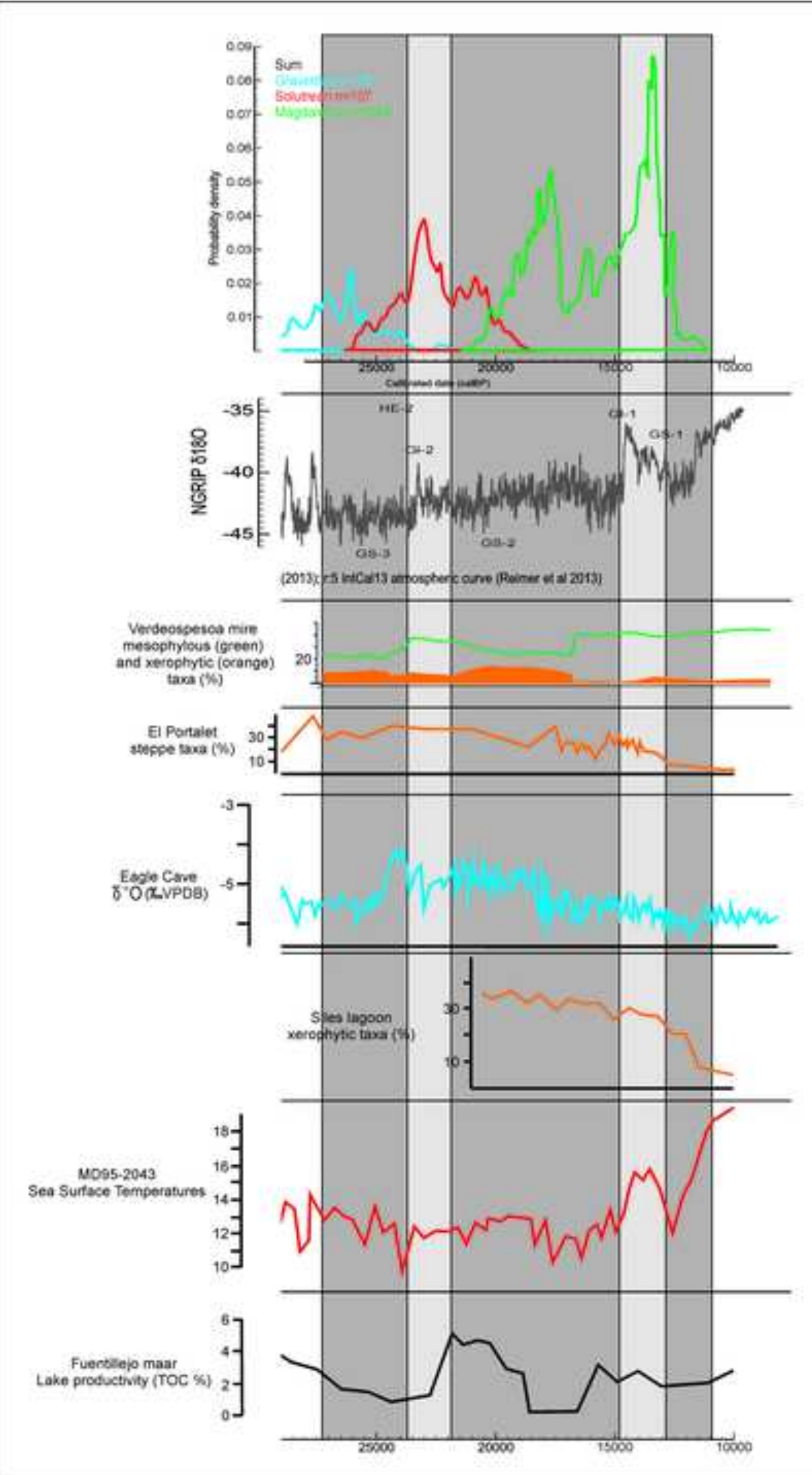




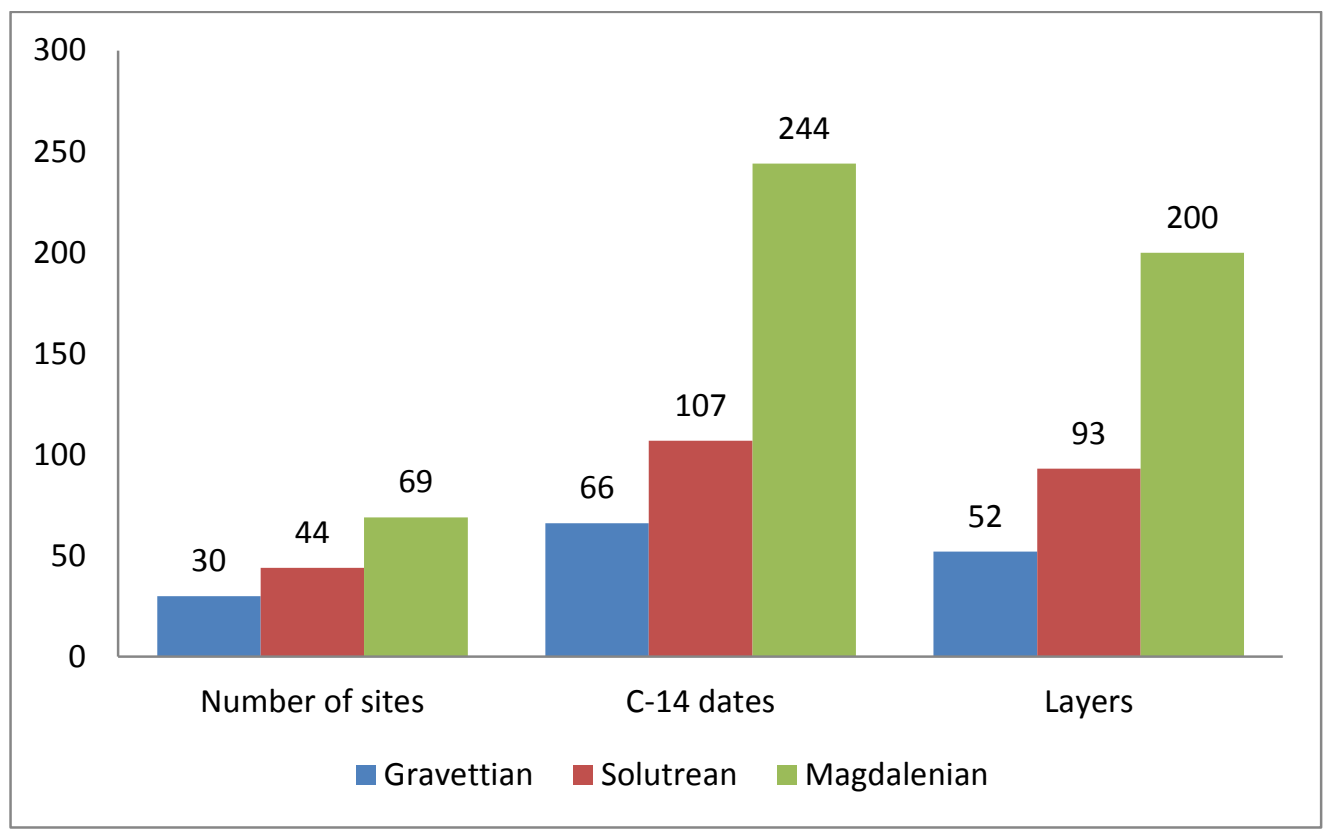




\begin{tabular}{cccccc} 
Depth Interval (cm) & Lab. Code & Material of sample & Age uncalibrated BP & Age cal BP & Median age (cal yr. BP) \\
\hline $179-180$ & Poz-63214 & Bulk & $7660 \pm 80$ & $8598-8341$ & 8464 \\
$199-200$ & Poz-63217 & Bulk & $13770 \pm 70$ & $16934-16364$ & 16646 \\
$207-208$ & Poz-66421 & Plant remains & $13890 \pm 90$ & $17133-16484$ & 16827 \\
$219-220$ & CNA-2391 & Bulk & $19570 \pm 60$ & $23834-23332$ & 23580 \\
$230-231$ & Poz-63215 & Bulk & $21050 \pm 120$ & $25684-25102$ & 25402 \\
$233-234$ & CNA-2392 & Plant remains & $23050 \pm 300$ & $27777-26640$ & 27321
\end{tabular}




\section{Sebastián Pérez-Díaz ${ }^{1}$ \& José Antonio López-Sáez ${ }^{2}$}

${ }^{1}$ Grupo de Investigación Pasado y Presente Grográfico del Relieve, la Vegetación y el Paisaje (GeoReVe), Departamento de Geografía, Urbanismo y Ordenación del Territorio, Universidad de Cantabria. E.T.S. de Ingenieros de Caminos, Canales y Puertos. Avenida de los Castros, 44, 39005, Santander, Spain. sebastian.perezdiaz@unican.es.

${ }^{2}$ Grupo de Investigación Arqueología Medioambiental, Instituto de Historia (IH), Centro de Ciencias Humanas y Sociales (CCHS), Consejo Superior de Investigaciones Científicas, C/ Albasanz 26-28, 28037 Madrid, Spain. joseantonio.lopez@cchs.csic.es.

In relation with the submission of the manuscript entitled: LATE PLEISTOCENE ENVIRONMENTAL DYNAMICS AND HUMAN OCCUPATION IN SOUTHWESTERN EUROPE

\section{Declaration of interests}

$\bigotimes$ The authors declare that they have no known competing financial interests or personal relationships that could have appeared to influence the work reported in this paper.

$\square$ The authors declare the following financial interests/personal relationships which may be considered as potential competing interests: 


\section{Quaternary International}

We the authors declare that this manuscript is original, has not been published before and is not currently being considered for publication elsewhere.

We confirm that the manuscript has been read and approved by all named authors and that there are no other persons who satisfied the criteria for authorship but are not listed. We further confirm that the order of authors listed in the manuscript has been approved by all of us.

We understand that the Corresponding Author is the sole contact for the Editorial process. $\mathrm{He} / \mathrm{She}$ is responsible for communicating with the other authors about progress, submissions of revisions and final approval of proofs.

Sincerely,

On behalf of all authors

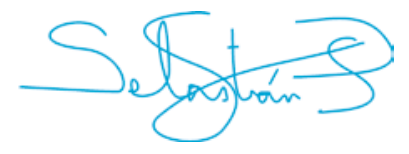

Sebastián Pérez Díaz

(corresponding author) 